Florida International University

FIU Digital Commons

7-22-2005

\title{
Analysis of fractured terrain using remote sensing and geographic information systems : establishing a correlation between fracture network properties and vegetation
}

Sumanjit Aich

Florida International University

Follow this and additional works at: https://digitalcommons.fiu.edu/etd

Part of the Other Environmental Sciences Commons

\section{Recommended Citation}

Aich, Sumanjit, "Analysis of fractured terrain using remote sensing and geographic information systems : establishing a correlation between fracture network properties and vegetation" (2005). FIU Electronic Theses and Dissertations. 1165.

https://digitalcommons.fiu.edu/etd/1165

This work is brought to you for free and open access by the University Graduate School at FIU Digital Commons. It has been accepted for inclusion in FIU Electronic Theses and Dissertations by an authorized administrator of FIU Digital Commons. For more information, please contact dcc@fiu.edu. 


\section{FLORIDA INTERNATIONAL UNIVERSITY}

Miami, Florida

ANALYSIS OF FRACTURED TERRAIN USING REMOTE SENSING AND

GEOGRAPHIC INFORMATION SYSTEMS: ESTABLISHING A CORRELATION

BETWEEN FRACTURE NETWORK PROPERTIES AND VEGETATION

A thesis submitted in partial fulfillment of the

requirements for the degree of

MASTER OF SCIENCE

in

GEOSCIENCES

by

Sumanjit Aich 
To: Interim Dean Mark Szuchman

College of Arts and Sciences

This thesis, written by Sumanjit Aich, and entitled Analysis of Fractured Terrain Using Remote Sensing and Geographic Information Systems: Establishing a Correlation between Fracture Network Properties and Vegetation, having been approved in respect to style and intellectual content, is referred to you for judgment.

We have read this thesis and recommend that it be approved.

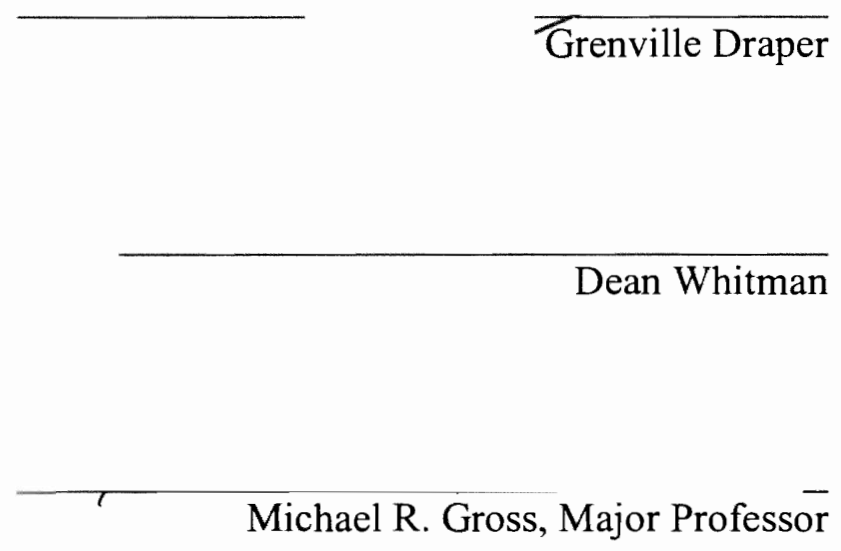

Date of Defense: July 22, 2005

The thesis of Sumanjit Aich is approved.

Interim Dean Mark Szuchman
College of Arts and Sciences

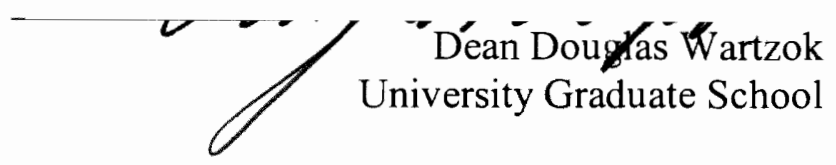

Florida International University, 2005 


\section{DEDICATION}

This thesis is dedicated to my parents, family and friends for their encouragement, affection and support. 


\section{ACKNOWLEDGMENTS}

I express my sincere thanks and gratitude to my advisor Dr. Michael R. Gross, who granted me the opportunity to study in the United States. I am greatly obliged to him for his expert guidance along with vigilant supervision, and cogent arguments that have prompted my understanding of the problem. I would also like to thank Dr. Grenville Draper and Dr. Dean Whitman for their comments, suggestions and insight into the riddles of my thesis.

Very few people are there in the world, who are loved and regarded for their innocuous goodness, honesty and simplicity. One such person is the department's secretary Ms. Bonnie Boddicker, for whom with pride I wish to register my heartfelt acknowledgement for her priceless help throughout the three years of my tenure as a graduate student in the Department of Earth Sciences. A woman of substance, who energized me to challenge the flustering endurance of conducting the undergraduate laboratory classes, is Mrs. Debby Arnold. Her whole hearted encouragement and faithful assistance at every level deserves special corner in my heart.

Funding from the grants of the United States Army Research Office and the United States Department of Energy supported my studies at this university. The American Association of Petroleum Geologists' Grant-in-Aid covered all of the costs of my field trip in Arches National Park, Utah.

I express my thankfulness to Alex Manda, who stood beside me as my mate during the tough times at various instances after my arrival at Miami. 
If there is a doubt of faith in God, then the truth is parents are above all. I have no words to express my reverence to my parents, who have taught me to dream and to reach my dreams. I dedicate this thesis to my parents, family and friends in India. 


\section{ABSTRACT OF THE THESIS \\ ANALYSIS OF FRACTURED TERRAIN USING REMOTE SENSING AND \\ GEOGRAPHIC INFORMATION SYSTEMS: ESTABLISHING A CORRELATION \\ BETWEEN FRACTURE NETWORK PROPERTIES AND VEGETATION}

by

Sumanjit Aich

Florida International University, 2005

Miami, Florida

Professor Michael R. Gross, Major Professor

This research analyzed the spatial relationship between a mega-scale fracture network and the occurrence of vegetation in an arid region. High-resolution aerial photographs of Arches National Park, Utah were used for digital image processing. Four sets of large-scale joints were digitized from the rectified color photograph in order to characterize the geospatial properties of the fracture network with the aid of a Geographic Information System. An unsupervised landcover classification was carried out to identify the spatial distribution of vegetation on the fractured outcrop. Results of this study confirm that the WNW-ESE alignment of vegetation is dominantly controlled by the spatial distribution of the systematic joint set, which in turn parallels the regional fold axis. This research provides insight into the spatial heterogeneity inherent to fracture networks, as well as the effects of jointing on the distribution of surface vegetation in desert environments. 


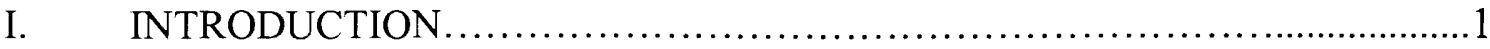

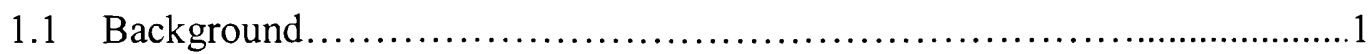

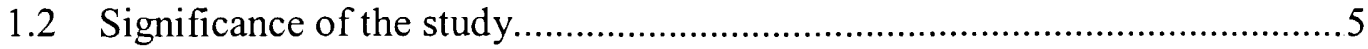

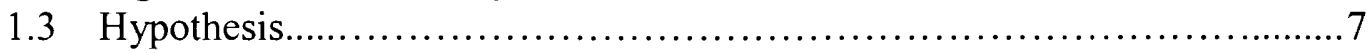

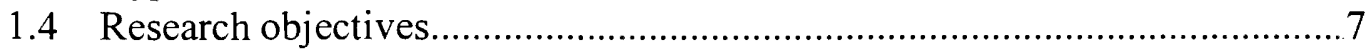

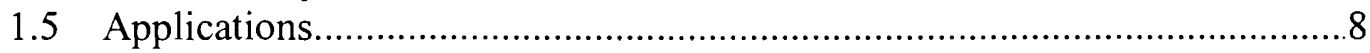

1.6 Contents of the thesis.................................................

II. GEOLOGICAL SETTING, IMAGE ACQUISITION AND

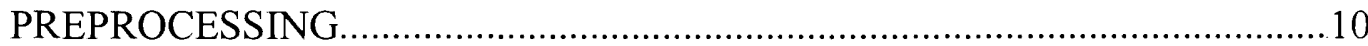

2.1 Geological setting of the study area...................................................... 10

2.1.1 Location of Arches National Park................................................10

2.1.2 Regional overview and structural style......................................11

2.1.3 Lithology and Stratigraphy......................................................13

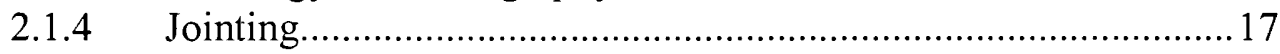

2.2 Acquisition of the digital images, and preprocessing

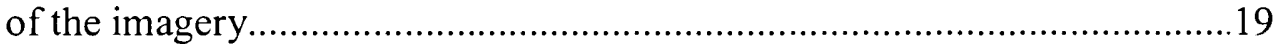

2.2.1 Digital Orthophoto Quarter Quadrangle (DOQQ).......................23

2.2.2 True color aerial photograph, and preprocessing

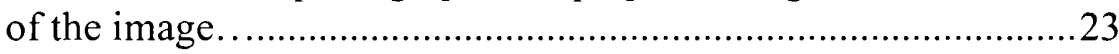

III. CHARACTERIZATION OF FRACTURE NETWORK ...................................29

3.1 Ground truthing and the field observations................................................29

3.2 Digitization of the fracture traces and creation of a

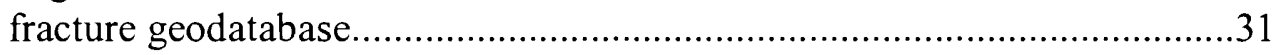

3.3 Vector analysis: characteristics of the fracture populations.........................34

3.3.1 Determination of fracture trace lengths and fracture

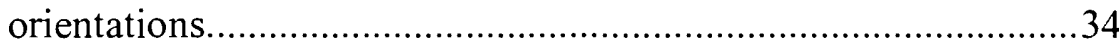

3.3.2 Fracture spacing measurements...................................................

3.4 Raster analysis: geospatial modeling of the fracture network.....................47

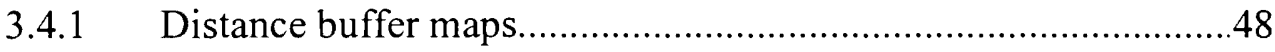

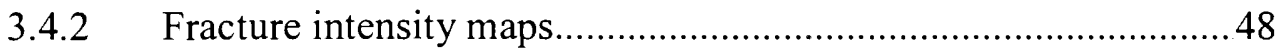

3.4.3 Density map of the fracture intersections.....................................56

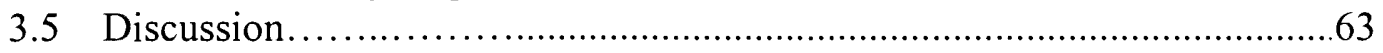

IV. LANDCOVER CLASSIFICATION .......................................69

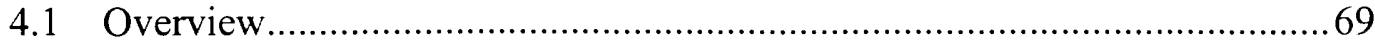

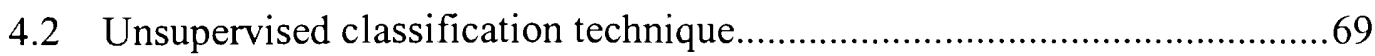

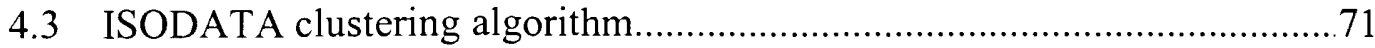

4.4 Separability analysis and class merging............................................. 73

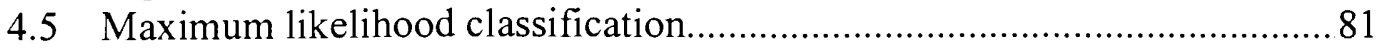




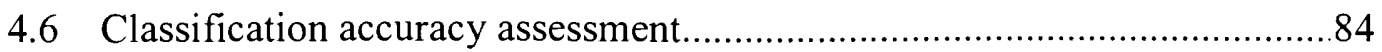

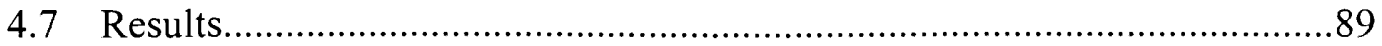

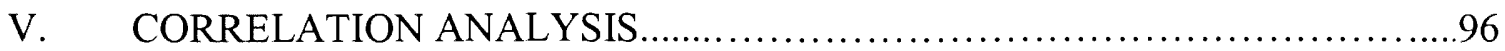

5.1 Spatial distribution and alignment of the vegetation zones.........................96

5.1.1 Generation of the vegetation map..............................................96

5.1.2 Focal operations and applications of filters..................................96

5.1.3 Defining the vegetation zones..................................................102

5.2 Correlation between the fracture network properties and alignment

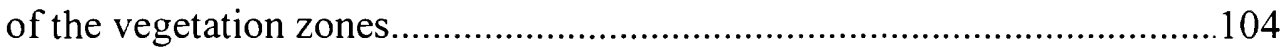

5.2.1 Correlation between the spatial distribution of fracture traces and the spatial distribution of vegetation zones.

5.2.2 Correlation between the fracture intensity and the spatial distribution of vegetation zones

5.2.3 Correlation between the density of fracture intersections and the spatial distribution of vegetation zones...........................105

5.2.4 Implication of fracture aperture.............................. 108

5.2.5 A circular argument............................................................ 108

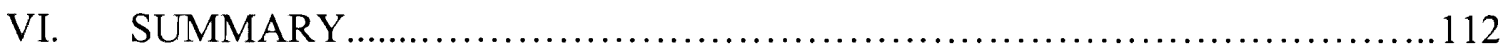

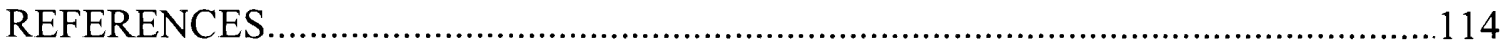




\section{LIST OF TABLES}

TABLE

PAGE

2.1 Specifications of the remotely sensed images (after USGS, USDA)...

3.1 Joint population statistics for the four sets of joints and the entire fracture network

3.2 Joint spacing statistics for the four joint sets obtained from scan line spacing measurements.

3.3 Statistics of proximity to nearest fracture as obtained from the distance buffer analysis.

3.4 Fracture intensity statistics as obtained from fracture intensity maps......

4.1 Mean spectral signature values for the six inseparable spectral clusters.

4.2 GPS ground truth locations within the study area, and description of the individual landcover types recorded. Refer to Fig. 2.10 for their spatial distribution.

4.3 Error matrix (a) and classification accuracies (b) derived from the accuracy assessment of the landcover classification. User's accuracy and producer's accuracy for individual landcover type is calculated. Kappa statistic for each category is computed (c).

4.4 Compilation of published accuracy assessments reported in the literature.

4.5 Area occupied by the three landcover types. 


\section{LIST OF FIGURES}

FIGURE

PAGE

1.1 Field photographs showing different types of meso-scale fractures.......................2

1.2 Subsurface contaminant migration at industrial facilities. In the porous medium, the dispersion of contaminants is slower and more predictable. However, the presence of bedrock fractures accelerates the transport of contaminants (after M. Gross). 3

1.3 The 'Geographic Information System' defined for this study is based on raster data input (in the form of aerial photographs), and vector data input (in the form of fracture trace maps), which are linked to their individual attribute tables (after ERDAS, 2002).

2.1 Location maps of the study area. (a) Location of Utah within the United States (after ESRI, 2002), (b) map of Utah showing location of Arches National Park, and (c) map of Arches National Park showing location of the study area.

2.2 Regional deformations within the Colorado Plateau region of southern Utah (after Davis, 1999).

2.3 Salt deformation in the Paradox Basin. (a) Field photograph of the eroded core of the Salt Valley anticline with view to SE,

(b) cross-sectional block diagram (after Doelling, 2000), and

(c) jointing due to outer-arc extension during folding, resulting in

fractures aligned parallel to the fold axis (Ramsay and Huber, 1987)

2.4 Geologic map of the Arches National Park area - Grand County, Utah (source : Utah Geological Survey).

2.5 Stratigraphy of Arches National Park area. (a) Lithologic column, and

(b) correlation diagram, showing formations and ages of rocks in Arches National Park. Shaded areas indicate when rocks were not deposited (after Doelling, 2000).

2.6 Two kinds of joint termination and intersection geometries observed on the fractured outcrop of the Moab Member of the Curtis Formation at Arches National Park, Utah. (a) Curving perpendicular, and (b) curving parallel geometries (after Dyer, 1988; Cruikshank and Aydin, 1995). 
2.7 Field Photographs. (a) Relationship between systematic joint (J-1) and cross joint (J-2), (b) systematic joint (J-1) and cross joints $(\mathrm{J}-3)$, and (c) curving perpendicular joint geometry. The Juniper trees are 8 to 10 feet in height.

2.8 Rectified color aerial photograph superimposed on the DOQQ.

(a) DOQQ (source : USGS), (b) rectified color aerial photograph (source : USDA), and (c) the study area.

2.9 Aerial photograph of the study area selected for analysis (source : USDA).

See Fig. 2.1 for location of the study area with reference to the Salt Valley anticline, Arches National Park, Utah

2.10 Geologic map of the study area, as traced from the color aerial photograph of the study area in Fig. 2.9. White area on the map represents the area of interest.......

3.1 Field photographs of the four different sets of joints. (a) Systematic joint (J-1), (b) cross joint (J-2) terminating against a systematic joint, (c) cross joints (J-3), and (d) non-systematic polygonal joints (J-4).

3.2 Spatial distribution of joints. (a) Systematic joints (J-1 set), (b) cross joints (J-2 set), (c) cross joints (J-3 set), and (d) non-systematic polygonal joints $(\mathrm{J}-4$ set $)$

3.3 Fracture trace map of the entire fracture network as digitized from the aerial photograph.

3.4 Characteristics of the population of the systematic (J-1) joint set.

(a) Frequency distribution of length, and (b) rose diagram of joints azimuths, class size is 20 . 36

3.5 Characteristics of the population of the cross (J-2) joint set.

(a) Frequency distribution of length, and (b) rose diagram of joints azimuths, class size is 20 .

3.6 Characteristics of the population of the cross (J-3) joint set.

(a) Frequency distribution of length, and (b) rose diagram of joints azimuths, class size is 20 . 38

3.7 Characteristics of the population of the non-systematic (J-4) joint set.

(a) Frequency distribution of length, and (b) rose diagram of joints azimuths, class size is 20 . 
3.8 Frequency distribution of (a) cumulative joint length, and (b) number of joints within the entire fracture network.

3.9 Schematic illustration showing the principle for the measurement of cross joint spacing using 1-D scan lines.

3.10 Scan lines are drawn perpendicular to the mean orientation of each joint set to measure joint spacing. (a) Scan lines trend NNE-SSW, (b) scan lines trend NE-SW, (c) scan lines trend NW-SE, and (d) scan lines trend WNW-ESE

3.11 Histograms showing frequency distribution of joint spacing measurements of (a) J-1 joint set, (b) J-2 joint set, (c) J-3 joint set, and (d) J-4 joint set.

3.12 Schematic illustration showing procedure for the generation of distance buffer maps. Dotted lines are distance buffer contours

3.13 Maps showing distance between fractures for (a) J-1 joint set, (b) J-2 joint set, (c) J-3 joint set, and (d) J-4 joint set. Cell size in all of the above maps is 0.3 meter

3.14 Map showing distance between fractures for the entire fracture network. Cell size is 0.3 meter.

3.15 Analysis of fracture intensity and fracture intersection intensity were carried out after excluding an area comprising of a 25 meters buffer zone towards the inside of the area of interest. This is performed to compensate for edge effect.

3.16 Fracture intensity is described as the mean total trace length of fractures per unit area. Hence, the unit of fracture intensity is $1 /$ length (after M. Gross).

3.17 Fracture intensity maps of (a) J-1 joint set, (b) J-2 joint set, (c) J-3 joint set, and (d) J-4 joint set. Cell size in all of the above maps is 0.3 meter and the search radius is 8 meters.

3.18 The intensity map of the entire fracture network. Cell size is 0.3 meter and search radius is 8 meters.

3.19 Histograms of fracture intensities for (a) J-1 joint set, (b) J-2 joint set, (c) J-3 joint set, and (d) J-4 joint set. .59

3.20 Frequency distribution of fracture intensity of the entire fracture network. .60 
3.21 Schematic illustration showing nodes of fracture intersections and fracture terminations.

3.22 Spatial distribution of fracture intersection nodes within the fracture network....62

3.23 Density map of the fracture intersections. Note distinct NW-SE trend. Cell size is 0.3 meter and the search radius is 9 meters.

3.24 Frequency distribution of fracture intersection density of the entire fracture network

3.25 Field photograph of a systematic joint (J-1). Note that vegetation is growing within the aperture of the joint, and thus partly obscuring the trace of the joint.

4.1 Three layers showing three bands of a multispectral image. Each pixel has three different digital numbers (DNs) in three bands (after ERDAS, 2002)

4.2 Schematic diagram of the ISODATA clustering algorithm. Filled circles signify cluster means (after ERDAS, 2002).

4.3 Starting from initial ISODATA twenty clusters, a simplified dendrogram could explain the steps of signature separability analysis, and sequential merging of spectral clusters to finally generate six inseparable clusters (denoted by filled rectangles).

4.4 Plots of mean spectral signatures for the six separable spectral classes, derived from ISODATA clustering and sequential merging of clusters. Error bars are drawn for one standard deviation. 78

4.5 Ellipse evaluation of spectral signatures. Filled circles signify signature means. (a) Overlapping signatures, and (b) distinct signatures (after ERDAS, 2002).

4.6 Signature separability in feature space for the six spectrally separable clusters. Filled circles signify signature means, and ellipses were drawn on the basis of one standard deviation. Note that the signature ellipses are distinct and do not overlap.

4.7 The landcover map generated after recoding of the classified aerial photograph.

4.8 Field photographs of the three major landcover types present within the study area. (a) Vegetation (Pine and Juniper trees), (b) sand, and (c) bedrock of Moab Member of the Curtis Formation. 
4.9 Distribution of the one hundred and fifty stratified random pixels over the area of interest, used for classification accuracy assessment.

4.10 Schematic flow chart summarizing the four main tasks performed as part of the classification process. (1) Cluster analysis that yields spectrally distinct classes, (2) reclassification of the image according to the results of the cluster analysis, (3) recoding the map into appropriate landcover categories, and (4) assessing the accuracy of the classification.

4.11 Pie chart showing distribution of different landcover categories within the area of interest.

4.12 Distribution of vegetation and sand pixels in the landcover map.

(a) Alignment of vegetation pixels, (b) linear trend of sand pixels, and

(c) patches of sand pixels.

4.13 Field photograph showing alignment of vegetation in a preferred orientation (NW-SE) on the northeastern limb of the Salt Valley anticline, Arches National Park, Utah.

5.1 Vegetation map of the study area, as derived from the landcover map in Fig. 4.7

5.2 Schematic diagram explaining the principle of a focal operation.

A moving filter window of a square filter kernel can be applied over the image for data reduction and/or data enhancement.

5.3 Focal operations carried out on the vegetation map in Fig. 5.1.

(a) statistical $5 \times 5$ max filtering, and (b) statistical $7 \times 7$

majority filtering. ' 0 ' is a pixel with 'No Data' value, and ' 1 ' represents a vegetation pixel

5.4 Filtered vegetation map, as obtained after application of focal operations. Note the WNW-ESE alignment of discrete vegetation zones

5.5 Rose diagram of the trends of the vegetation zones, as calculated from the filtered vegetation map in Fig. 5.4. Cell size is 20.

5.6 Map overlay analysis between the fracture intensity map and the vegetation map.

5.7 Map overlay analysis between the fracture intersections density map and the vegetation map. 
5.8 Traces of open fractures digitized from the color aerial photograph.
(a) Aerial photograph of a region on the fractured outcrop, and
(b) fracture traces mapped on the photograph along fracture segments

devoid of vegetation..

5.9 Rose diagram of the trends of fracture segments, which are not obscured by vegetation. Cell size is 20 . . . 


\section{Chapter 1}

\section{INTRODUCTION}

\subsection{Background}

Fractures such as joints, faults and veins are non-sedimentary mechanical discontinuities thought to represent surfaces or zones of mechanical failure (Hancock, 1985; Pollard and Aydin, 1988; Twiss and Moores, 1992; Crider and Peacock, 2004). Dispersed throughout the earth's upper crust, fractures are among the most abundant deformational features in sedimentary rocks (Fig. 1.1). Some hydrocarbon reservoirs and groundwater aquifers are naturally fractured, resulting in a large network of permeable fractures of varied dimensions, orientations and densities (Nelson, 1985). Thus a good understanding of the geometric properties of fracture populations is critical for groundwater modeling, contaminant transport (Fig. 1.2) or evaluation of rock mass stability.

Quantification and analysis of the geometric properties of fracture populations are important for exploration and determination of production strategies in fractured reservoirs, as well as for modeling contaminant transport through fractured aquifers. Mechanical boundaries and lithologic variations in sedimentary rocks control the dimensions and physical attributes of opening mode fractures, which influence their scaling relations (Gross, 1993). Structural discontinuities may also serve as mechanical layer boundaries. This occurs when nonsystematic cross joints abut against a set of preexisting joints (Hodgson, 1961; Dyer, 1988; Dunne and North, 1990). 

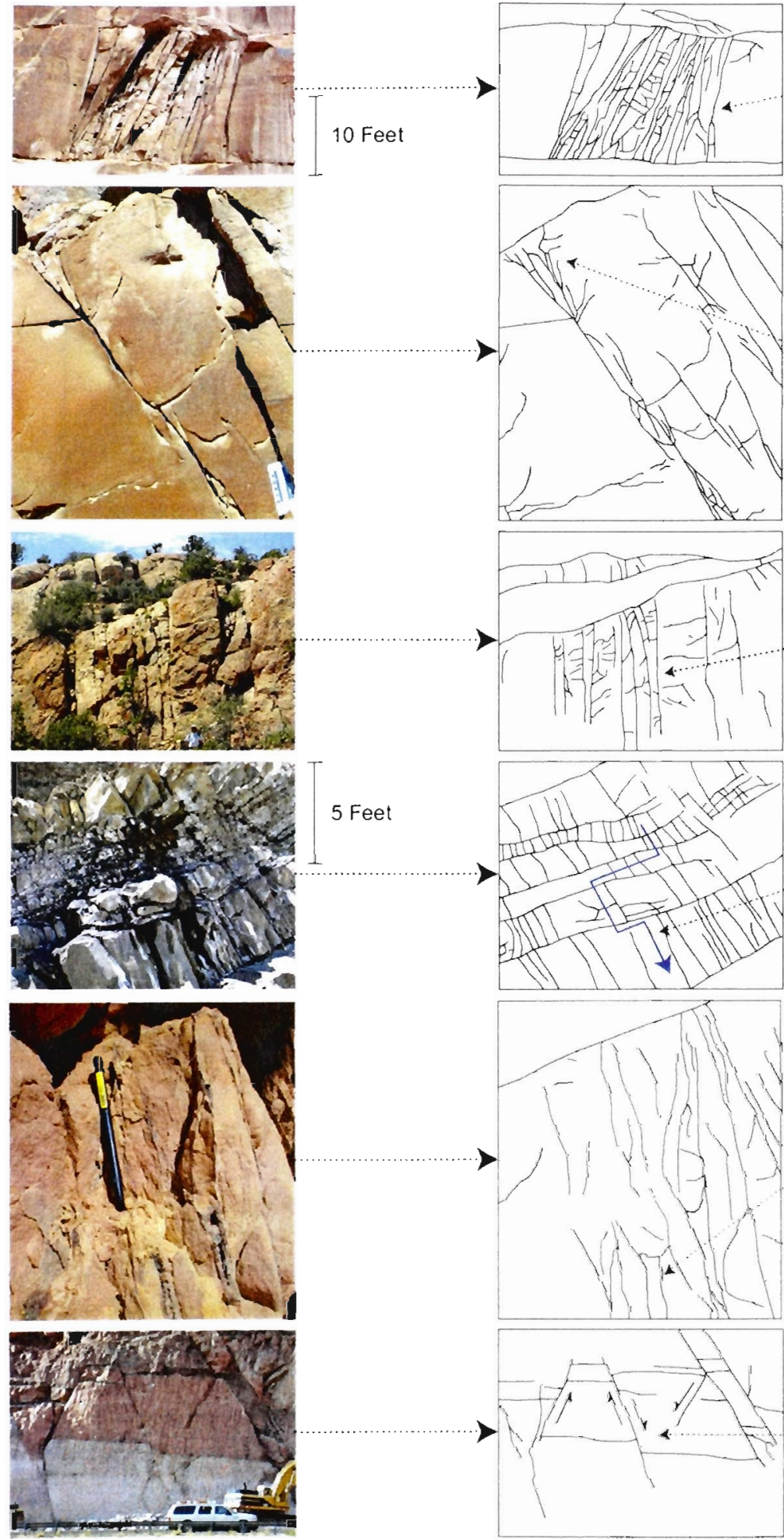
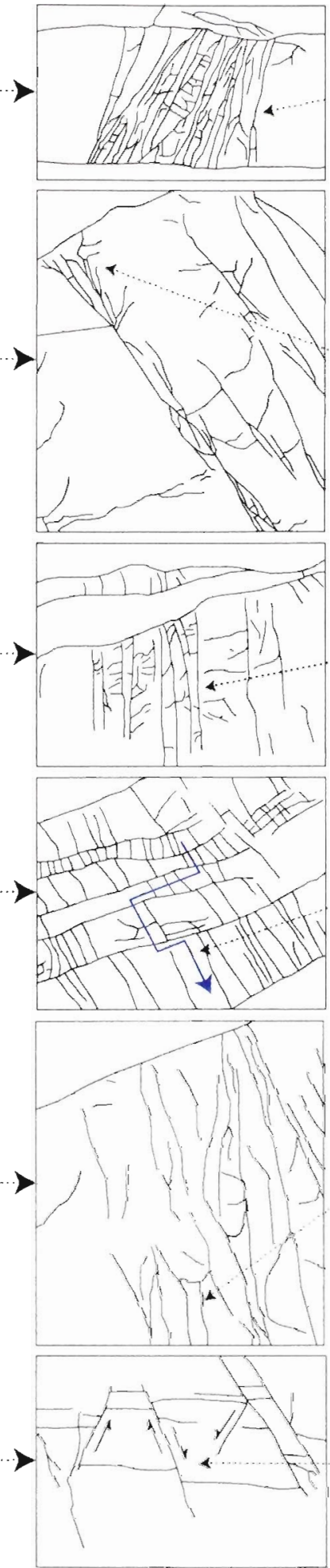

Horsetail Fractures,

Arches National Park, Utah.

Feather Joints,

Split Mountain, Utah.

Fracture Zone,

Arches National Park, Utah.

Seepage of Groundwater through Joints, Redstone, Colorado.

Opening Mode Fractures filled up by Secondary Materials forming Veins, Split Mountain, Utah.

Conjugate Faults producing Horst and Graben Structures, Moab, Utah.

Figure 1.1 Field photographs showing different types of meso-scale fractures. 


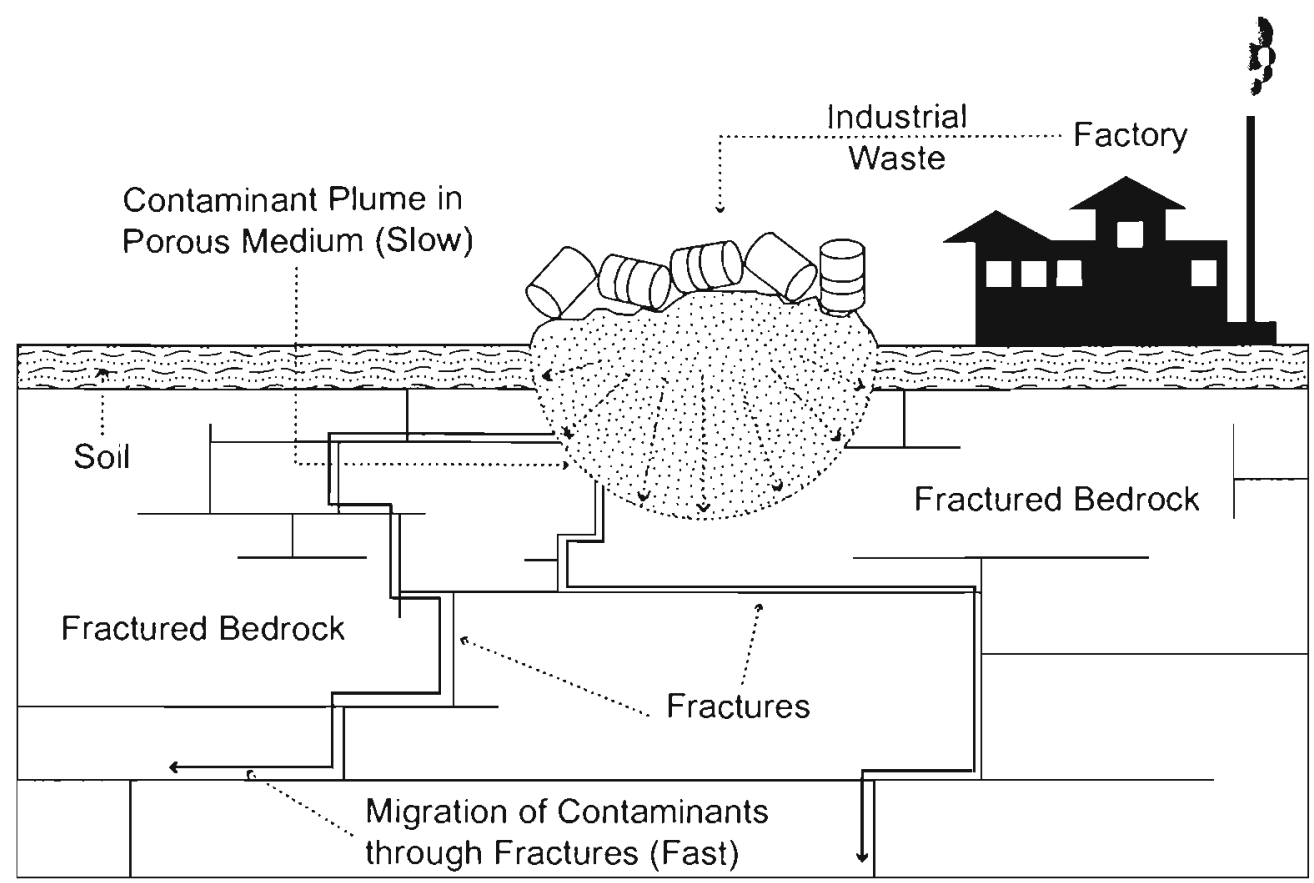

Figure 1.2 Subsurface contaminant migration at industrial facilities. In the porous medium, the dispersion of contaminants is slower and more predictable. However, the presence of bedrock fractures accelerates the transport of contaminants (after M. Gross). 
Many attributes of fractures are scale independent (Marrett and Allmendinger, 1991; Gross and Engelder, 1995; Schlische et al., 1996). The same geometric relationships and relative dimensions observed in microfractures (as observed in thin sections) are also obvious in fractures on the outcrop scale (meso-scale) and large fracture zones observed from aerial photos or satellites (mega-scale). The scale invariance of fracture populations and fracture properties provides the ability to collect data over a limited range of scale and to extrapolate those fracture characteristics to a wider range beyond the scale of direct observation (Scholz and Cowie, 1990; Walsh et al., 1991; Marrett and Allmendinger, 1992; Walsh and Watterson, 1992). Fracture scaling relations when applied correctly can thus greatly enhance the geoscientist's understanding of fractured rock beneath the earth's surface. As a part of this study, I quantified the characteristics of fractures whose length dimensions fall within the range of meters to tens of meters.

Fluid flow through fractured rocks depends upon the physical characteristics of the fractures such as fracture length and fracture spacing. Although procedures have been developed to characterize rock masses by quantifying fracture attributes such as spacing, length, connectivity and fractal dimension (Priest and Hudson, 1976; La Pointe and Hudson, 1985; Narr and Suppe, 1991; Wu and Pollard, 1995; Renshaw, 1997; Gillespie et al., 2001; Mauldon et al., 2001; La Pointe, 2002; Peacock et al., 2003), these techniques are incapable of distinguishing the spatial heterogeneity within fracture networks - a concern of great significance due to the varied nature of fracture populations. 
The heterogeneity in fracture populations can be properly addressed using a Geographic Information System (GIS), a spatial analysis tool that offers a wide range of functionality to deal with a variety of spatial data types (Bonham-Carter, 1994; Coburn and Yarus, 2000; Clarke, 2001). GIS is "an information system that is designed to work with data referenced by spatial or geographic coordinates. In other words, a GIS is both a database system with specific capabilities for spatially referenced data, as well as a set of operations for working with the data" (Star and Estes, 1990). Advantages of a GIS are its ability to perform spatial analyses on sizeable datasets and produce maps derived from these analyses (Coburn and Yarus, 2000). Hence, GIS is well suited for analyzing discontinuous features such as bedrock fractures (Finn, 2000; Ghosh, 2003).

I applied GIS techniques (Fig. 1.3) to a fractured geologic terrain within Arches National Park, Utah. The area is located on the northeastern limb of the Salt Valley anticline, where mega-scale fractures are exposed within the Moab Member of the Jurassic Curtis Formation. A color aerial photograph produced by the U.S. Department of Agriculture was used as source data for the mapping of remotely sensed fractures, and to perform subsequent landcover classification to investigate the potential correlation between fracture network properties and the distribution of desert vegetation.

\section{$1.2 \quad$ Significance of the study}

The purpose of this study was to develop new techniques to analyze and understand the spatial distribution of fracture networks, investigate methods for mapping fractures from aerial photographs and portray the spatial distribution of heterogeneity 

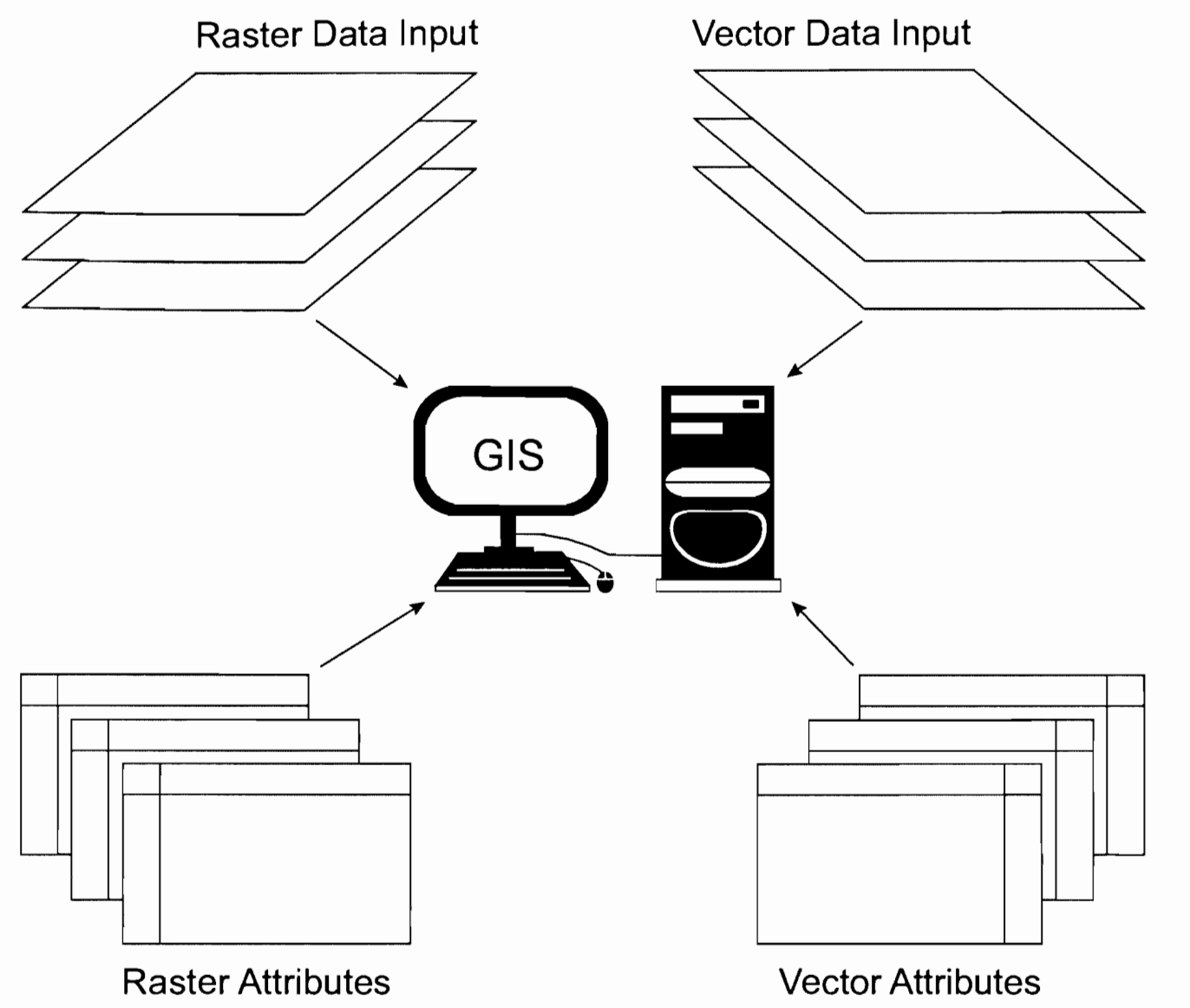

Figure 1.3 The 'Geographic Information System' defined for this study is based on raster data input (in the form of aerial photographs), and vector data input (in the form of fracture trace maps), which are linked to their individual attribute tables (after ERDAS, 2002). 
within fracture networks with the aid of a Geographic Information System. The project focused on quantifying the two-dimensional distribution of fractures and characterizing the geometric attributes of fracture populations, which influence groundwater flow in fractured rock and sustain vegetation in arid climates.

\subsection{Hypothesis}

I tested the hypothesis that there is a correlation between fracture network properties and the occurrence of vegetation in Arches National Park, Utah. Regions of high fracture intensity serve as major pathways for fluid flow. Further, places where cross joints intersect systematic joints (fracture intersection nodes) are potential locations of groundwater movement that sustain the growth of vegetation. Zones of high fracture intensity are indicative of fracture clustering. Such regions will likely experience enhanced desert erosion, contribute to local drainage and movement of groundwater, and subsequently should encourage the growth of vegetation.

\subsection{Research objectives}

My research objectives were as follows:

(i) establish techniques to (a) map fracture traces from remotely sensed data, and (b) incorporate the fracture data into a GIS database for subsequent geospatial analysis; 
(ii) characterize the fracture network through analyses of (a) different fracture set populations individually, and (b) overall fracture network attributes as a whole;

(iii) classify landcover on the northeastern limb of the Salt Valley anticline in order to facilitate the comparison between vegetation and attributes of fracture populations;

(iv) analyze potential correlations between vegetation and fracture network properties.

Although considerable research has focused on fracture scaling, only a few papers are devoted to mapping mega scale fractures from remotely sensed aerial photographs (Odling, 1997; Gillespie et al., 2001). To the best of my knowledge, this marks the first attempt to investigate the spatial heterogeneity within large scale fracture networks with the aid of a GIS, and correlate that heterogeneity to vegetation growth using digital image processing techniques.

\subsection{Applications}

Characterization of the spatial distribution of fractures is essential as fractures significantly influence the hydrological character and stability of a rock mass. The clustering of fractures intensifies fluid flow within a fracture network, which in turn may localize the distribution of groundwater recharge and the growth of vegetation. This study may contribute to the understanding of heterogeneity within complex fracture systems, groundwater flow through fracture networks in desert environments, and effects of jointing on the distribution of surface vegetation. Scientific implications of this research 
include identifying corridors of fluid flow in the subsurface, recognizing significant groundwater recharge areas through landcover analysis, and establishing the correlation between vegetation and the fracture network properties.

\subsection{Contents of the thesis}

Succeeding the introductory chapter, the second chapter deals with geological setting of the study area, image acquisition and preprocessing. Characterization of the fracture network has been discussed in the third chapter, followed by the landcover classification in the fourth chapter. Chapter five describes the correlation analysis, and chapter six summarizes the thesis. 


\section{Chapter 2}

\section{GEOLOGICAL SETTING, IMAGE ACQUISITION, AND PREPROCESSING}

\subsection{Geological setting of the study area}

\subsubsection{Location of Arches National Park}

Arches National Park is located in eastern Utah, between Interstate 70 and the Colorado River (Fig. 2.1a,b). The park is within the Canyonlands Section of the northcentral Colorado Plateau, which is an area of numerous meandering canyons cut by the Colorado River and its tributaries that originate in the Rocky Mountains to the east (Harris et al., 2004). Lying entirely within Grand County, the park has the greatest concentration of rock arches in the world (Adkinson, 2001). The park area is situated within the heart of the fault and fold belt of the Pennsylvanian Paradox Basin, and covers around 114 square miles of semiarid, rugged and sparsely populated desert terrain (Doelling, 1985). Red rocks dominate this area and hence the area is also known as the Red Rock Country (Baars, 1993).

Professor Lawrence M. Gould of the University of Michigan was the first to recognize the geologic and scenic values of Arches National Park. Spectacular erosional features such as deep canyons, steep escarpments, towering monoliths, slickrock terraces, petrified cross-bedded sand dunes, diapirs, salt-cored valley, wind eroded stone arches, rock fins, mesas, buttes, cuestas and hogbacks are exposed within the park area (Doelling, 1985). The region contains economic mineral deposits of uranium, copper, 
gold, manganese and gypsum (Doelling et al., 1988). Because of the presence of abundant oil and natural gas, petroleum drill holes are scattered across the area (Utah Geological Survey, 2001).

Salt flowage, subsurface salt dissolution, gliding of the rocks above salt and salt intrusion caused by erosion of the Colorado River and its tributaries, resulted in the bulging of Salt Valley anticline and development of complicated fracture patterns within Arches National Park (Doelling, 1985; Doelling et al., 1988). The present study area is located on the northeastern limb of the Salt Valley anticline (Fig. 2.1c). The park is drained entirely by the Colorado River, whose deep canyon borders the park on the southeast. Principal access to the park is through a paved entry road that branches off U.S. Highway 191. The highway intersects with Interstate 70, twenty seven miles north of the park's entry at Crescent Junction. The town of Moab is a few miles south of the park entrance and the visitor center.

\subsubsection{Regional overview and structural style}

The Mesozoic rocks of southern Utah have undergone three major regional tectonic deformations (Burchfiel et al., 1992; Wilkerson, 1993; Reading et al., 1998; Davis, 1999; Sprinkel et al., 2003). The first deformation occurred during the Laramide orogeny (90 to $50 \mathrm{Ma}$ ), when tectonic convergence between the North American plate and the Farallon plate caused horizontal compression, resulting in the contraction of the Colorado Plateau (Moores and Twiss, 1995). Contraction was accommodated by basement-cored thrusting, reverse and oblique-slip faulting, as well as associated diapiric 


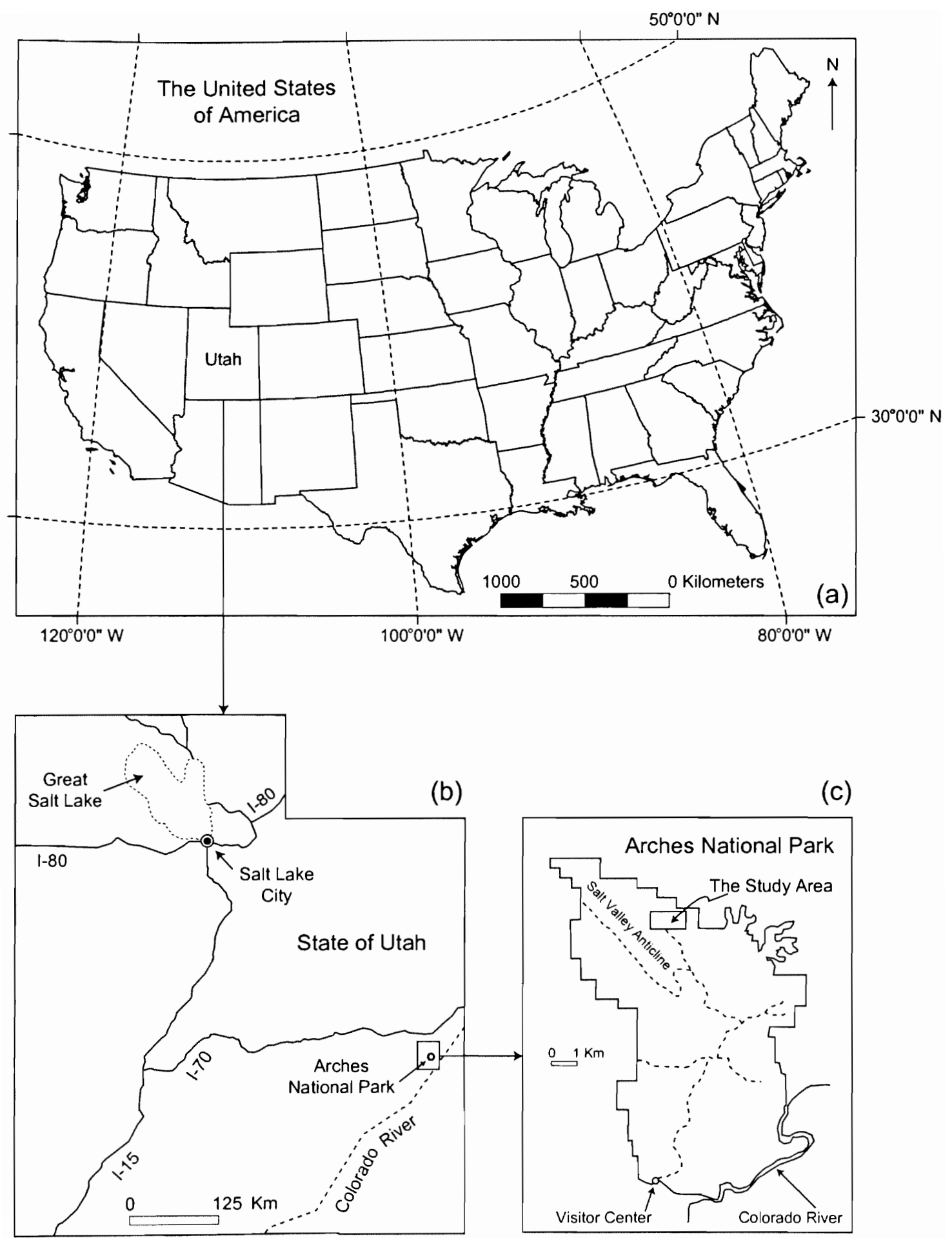

Figure 2.1 Location maps of the study area. (a) Location of Utah within the United States, (b) map of Utah showing location of Arches National Park, and (c) map of Arches National Park showing location of the study area. 
folding in numerous broad northwest trending salt anticlines and synclines (Doelling, 1985; Hintze, 1988, 1997; Figs. 2.2, 2.3a,b). The second deformation phase in southern Utah took place during the Miocene (25 to $19 \mathrm{Ma}$ ). Magmatism induced by subduction was well developed in the foreland region of the Colorado Plateau, which produced laccoliths and associated domes (Davis, 1999; Fig. 2.2). The third phase of deformation was the Basin and Range extensional faulting, which initiated $15 \mathrm{Ma}$ and is still active at present (Kearey and Vine, 1996; Fig. 2.2).

Structures of the Arches National Park area were formed by regional tectonic and salt induced events (Doelling et al., 1988; Harris et al., 2004). The dominant structural feature of the area is the diapiric Salt Valley anticline (Figs. 2.3a,b, 2.4). Many closelyspaced faults parallel this diapiric intrusion structure. Most of these faults are of small displacements, but a few such as Moab fault are of relatively large displacement (Foxford et al, 1998; Garden et al., 2001; Fig. 2.4). Important information on the kinematics and mechanics of brittle deformation are recorded in outcrop-scale shear zones, which occur in porous sandstones as deformation bands and zones of deformation bands (Antonellini et al., 1994; Antonellini and Pollard, 1995). These deformation bands are abundant in the Jurassic Navajo Sandstone and the Entrada Sandstone Formations (Stokes, 1986; Davis, 1999).

\subsubsection{Lithology and Stratigraphy}

A wide variety of lithological units outcrop in the Arches National Park area (Fig. 2.4). The rock types extend from the Pennsylvanian Paradox Formation to recent 


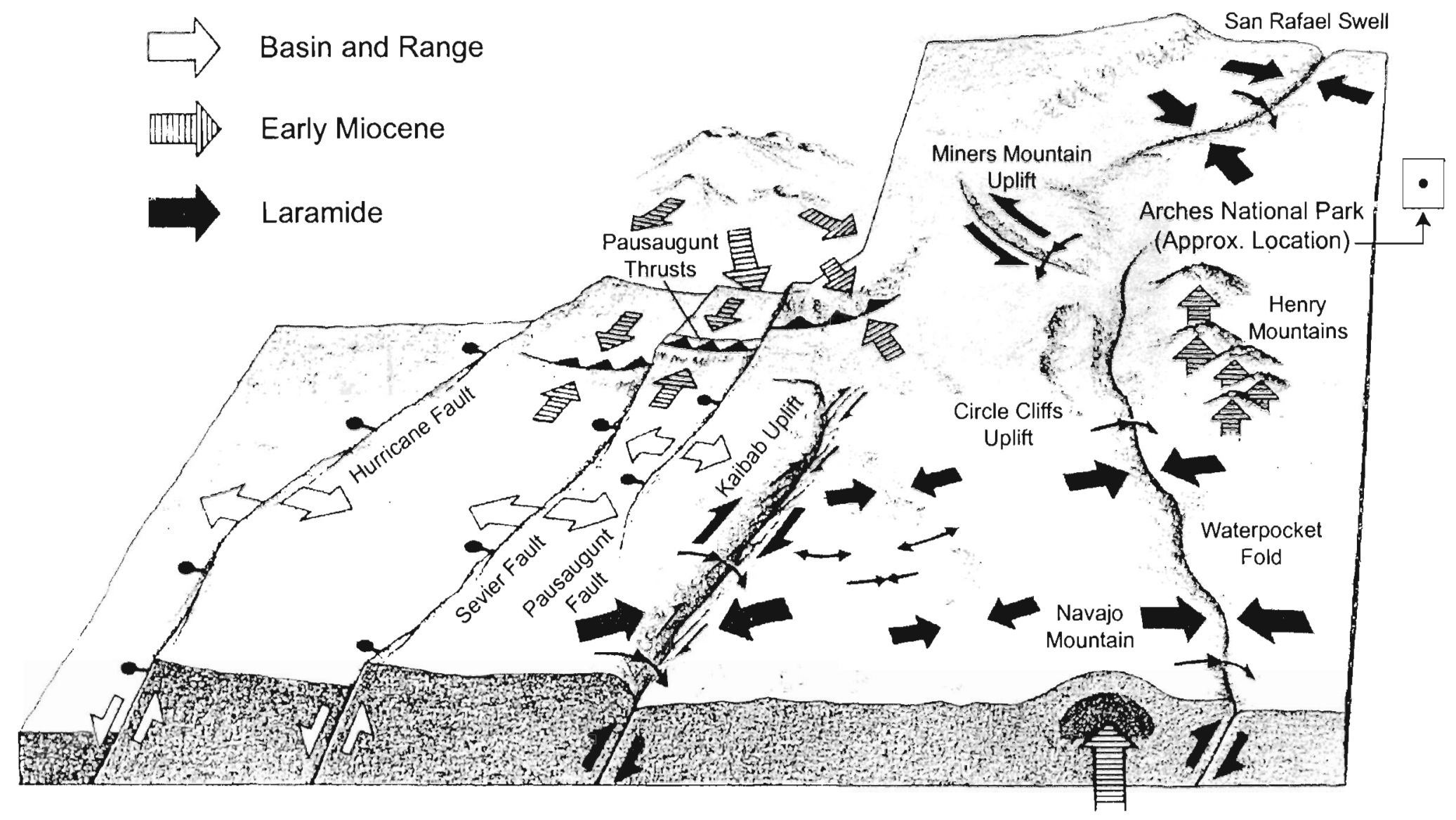

Figure 2.2 Regional deformations within the Colorado Plateau region of southern Utah (after Davis, 1999). 


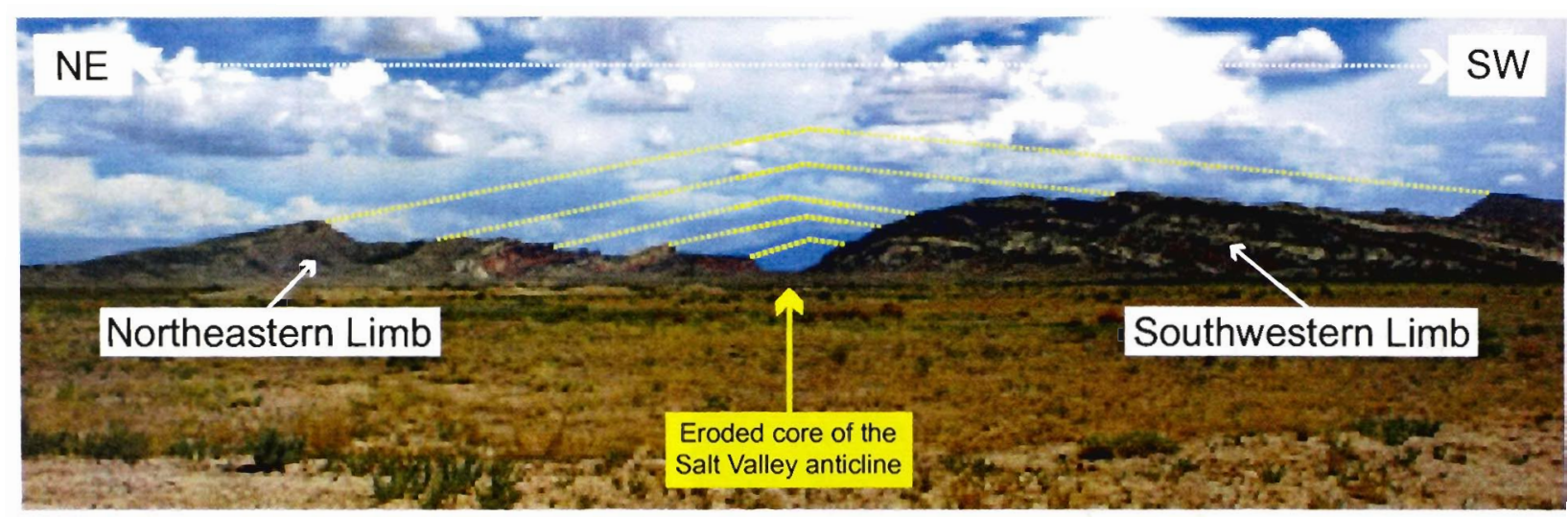

(a)

SW
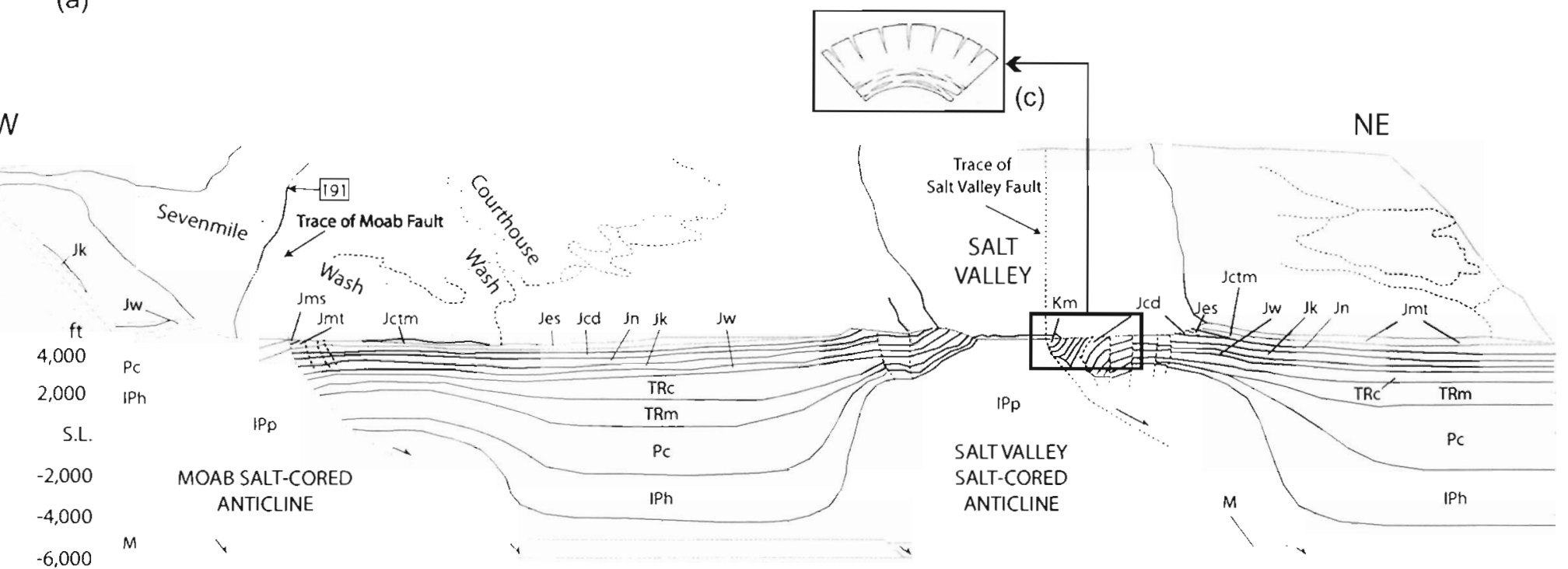

Figure 2.3 Salt deformation in the Paradox Basin. (a) Field photograph of the eroded core of the Salt Valley anticline with view to SE, (b) cross-sectional block diagram (after Doelling, 2000), and (c) jointing due to outer-arc extension during folding, resulting in fractures aligned parallel to the fold axis (Ramsay and Huber, 1987). 

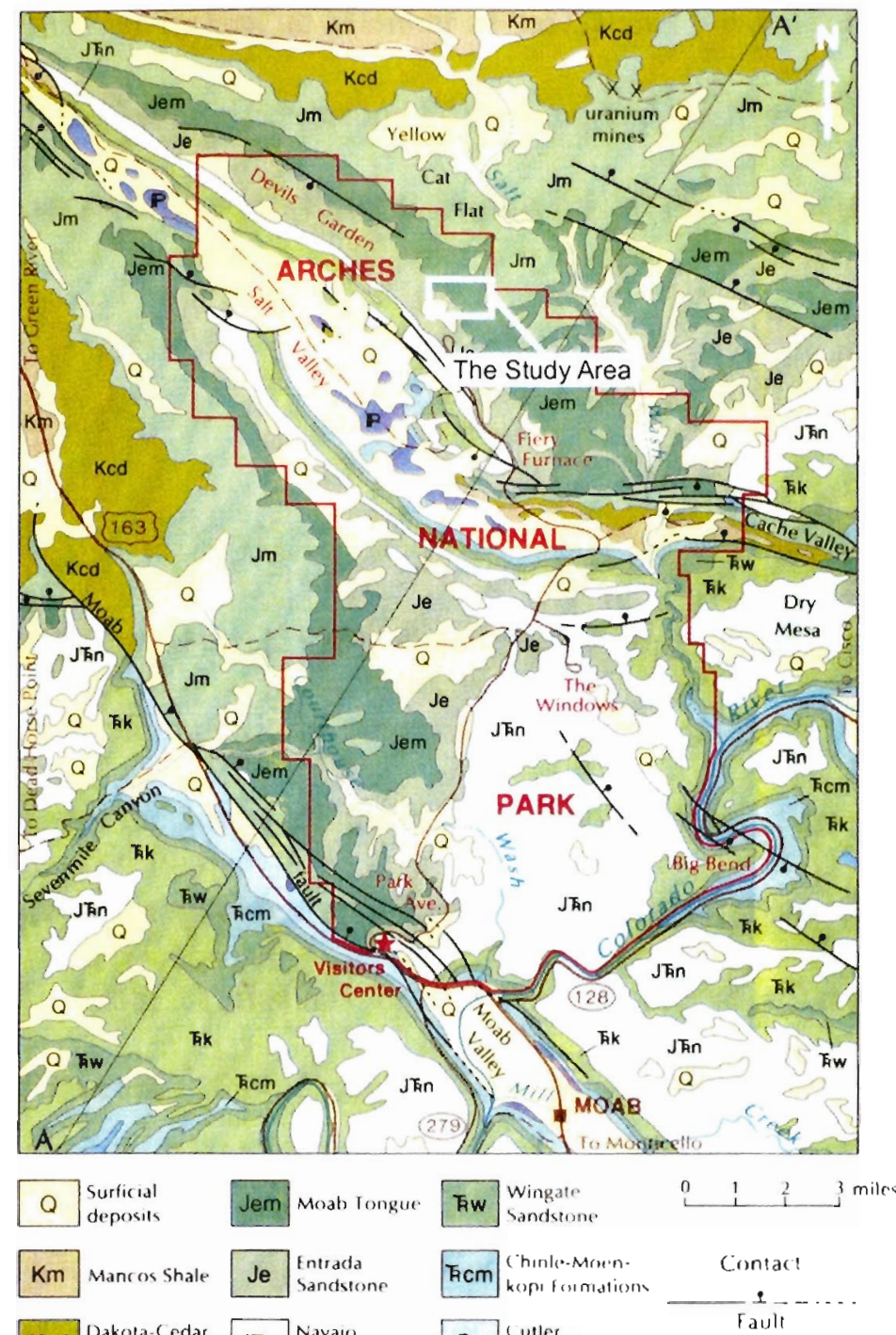

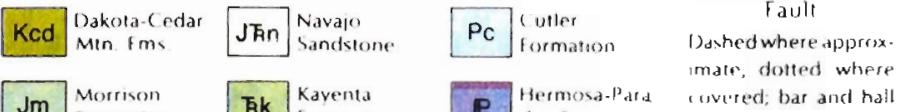

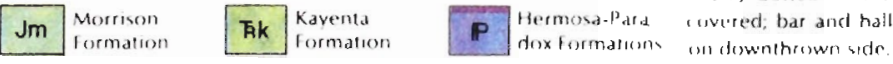

Figure 2.4 Geologic map of the Arches National Park area - Grand County, Utah (source : Utah Geological Survey). 
surficial alluvial deposits (Doelling et al., 1988). However, three geologic formations are primarily exposed - the Dewey Bridge Member of the Carmel Formation, the Slick Rock Sandstone Member of the Entrada Sandstone Formation, and the Moab Member of the Curtis Formation, in ascending order. Refer to Figure 2.5 for the entire stratigraphy of Arches National Park.

\subsubsection{Jointing}

As first reported by Dyer (1988), excellent outcrops of large scale systematic joints and cross joints are found within the resistant sandstones of the Moab Member of the Curtis Formation on the limbs of the Salt Valley anticline (Figs 2.3a,c). Several researchers have studied the geology and brittle deformation of this region (Doelling, 1985; Doelling et al., 1988; Cruikshank et al., 1991; Zhao and Johnson, 1991, 1992; Baars, 1993; Antonellini et al., 1994; Cruikshank and Aydin, 1994, 1995; Antonellini and Pollard, 1995; Davis, 1999; Kattenhorn et al., 2000; Lorenz and Cooper, 2001). The jointing is thought to have taken place due to collapse of the limbs of the Salt Valley anticline into its eroded core (Doelling et al., 1988; Fig. 2.3). Later, wind erosion along the joints gave rise to the development of arches and rock fins.

Three sets of opening-mode fractures are prominently developed at Arches National Park (Dyer, 1988; Zhao and Johnson, 1992). Individual fractures are confined to the Moab Member of the Curtis Formation. Younger joints show a systematic change in orientation as they approach older throughgoing joints (Dyer, 1988; Cruikshank and Aydin, 1995). The younger joints either curve parallel or curve perpendicular to the older 
(a)

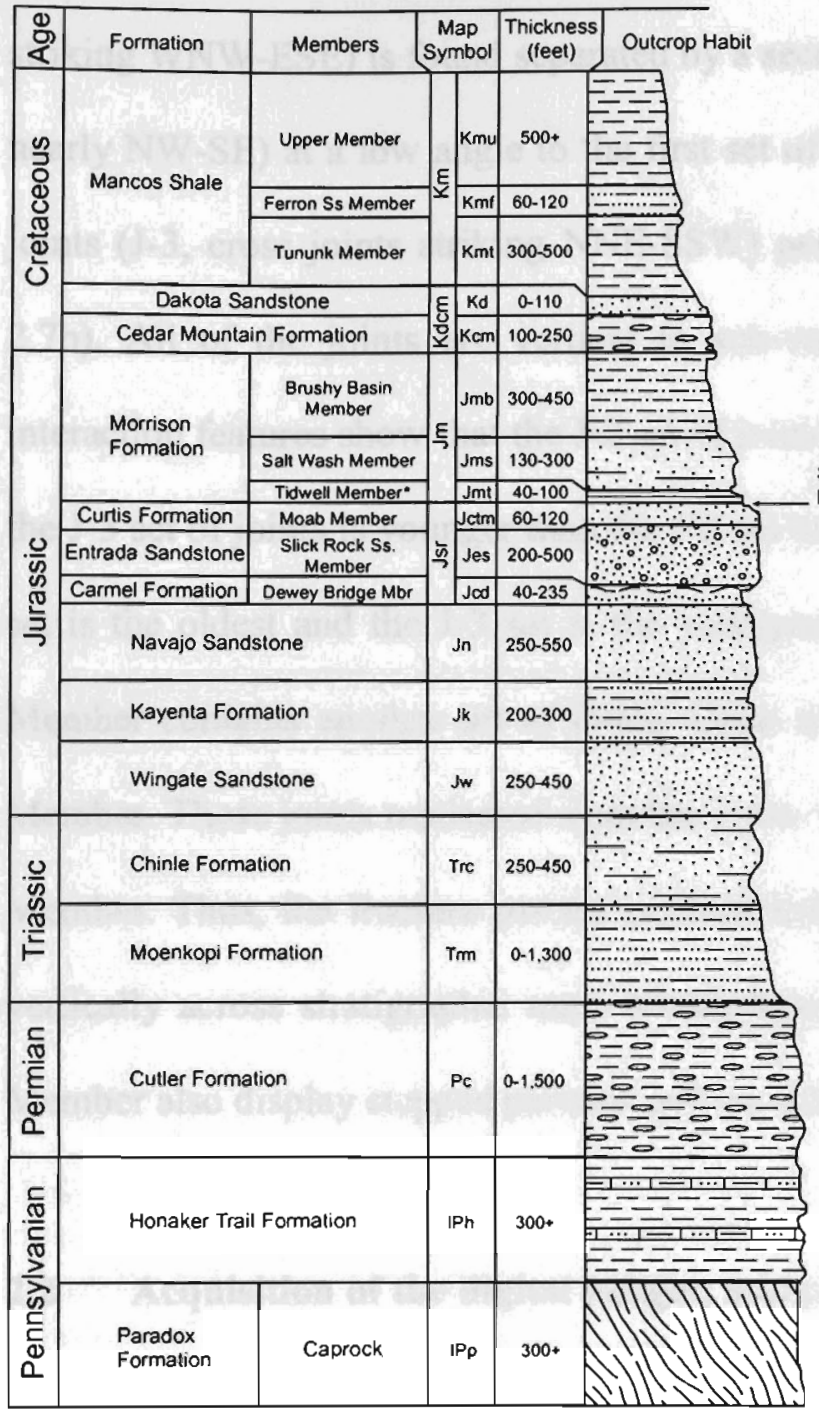

- Includes a thin section of the Summerville Formation at the base. that is generally less than 10 feet thick. (b)

$\mathrm{Ma}$
75

100

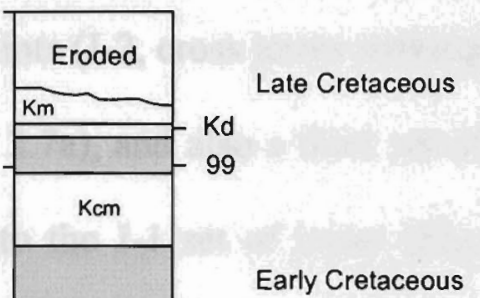

150

Summerville Formation

125

175

5

200
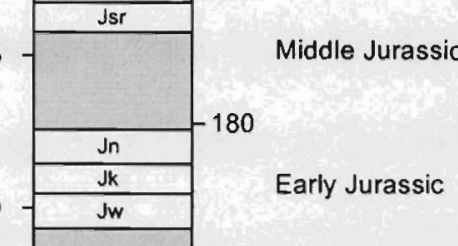

Middle Jurassic

180

206

Late Triassic

225

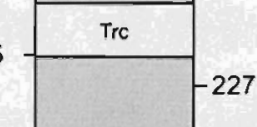

Middle Triassic

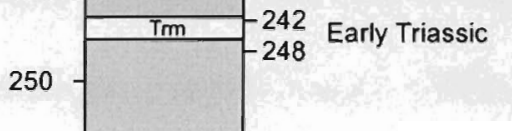

Permian

275

300

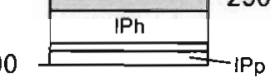

Pennsylvanian

Figure 2.5 Stratigraphy of Arches National Park area. (a) Lithologic column, and (b) correlation diagram, showing formations and ages of rocks in Arches National Park. Shaded areas indicate when rocks were not deposited (after Doelling, 2000). 
joints (Figs. 2.6, 2.7c). Within the Moab Member, a single joint set (J-1, systematic joints striking WNW-ESE) is found separated by a second set of joints ( $\mathrm{J}-2$, cross joints striking nearly NW-SE) at a low angle to the first set of joints (Fig. 2.7a), and also a third set of joints (J-3, cross joints striking NNE-SSW) perpendicular to the J-1 set of joints (Fig. 2.7b). All of the joints are vertical to sub-vertical. Cross-cutting relations and joint interaction features show that the J-2 set of joints is younger than the J-1 set of joints, and the J-3 set of joints is younger than the J-2 set of joints (Dyer, 1988). Hence, the J-1 joint set is the oldest and the J-3 set is the youngest. The underlying Slick Rock Sandstone Member contains another set of joints which are at an angle to the joints in the Moab Member. Those joints nucleated from the lower edges of the joints in the overlying Moab Member. Thus, the fracture pattern evolved both horizontally within the same unit and vertically across stratigraphic units (Cruikshank and Aydin, 1995). Joints in the Moab Member also display stepped patterns and en-echelon geometries (Matthai et al., 1998).

\subsection{Acquisition of the digital images, and preprocessing of the imagery}

An aerial photograph is a photograph of the earth's surface taken with a camera mounted in an airplane, which can be used in cartography to provide geographic information for base maps (Jensen, 2000; Kennedy, 2001; Paine and Kiser, 2003). To facilitate mapping of fracture traces from remotely sensed aerial photographs and to incorporate the fracture data into a GIS database for subsequent geospatial analysis, two different kinds of aerial photographs of the study area were used as source imagery (Table 2.1). 


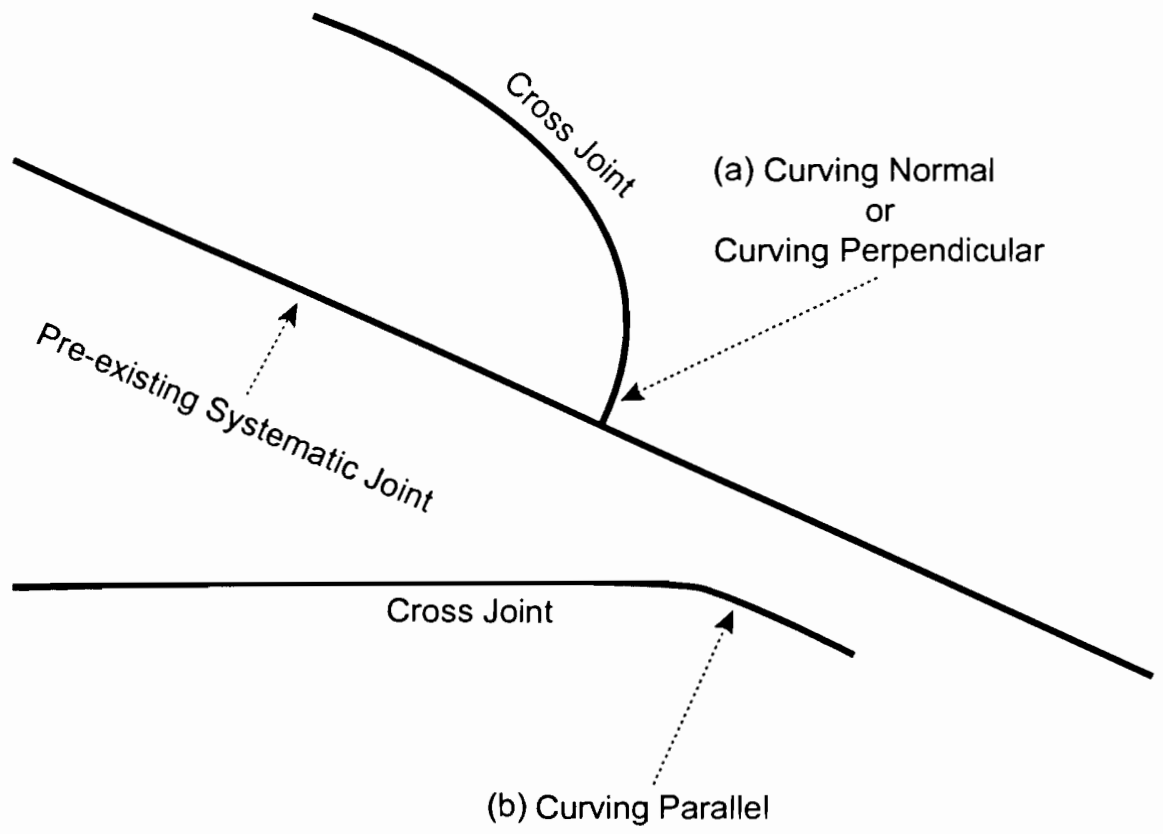

Figure 2.6 Two kinds of joint termination and intersection geometries observed on the fractured outcrop of the Moab Member of the Curtis Formation at Arches National Park, Utah. (a) Curving perpendicular, and (b) curving parallel geometries (after Dyer, 1988; Cruikshank and Aydin, 1995). 


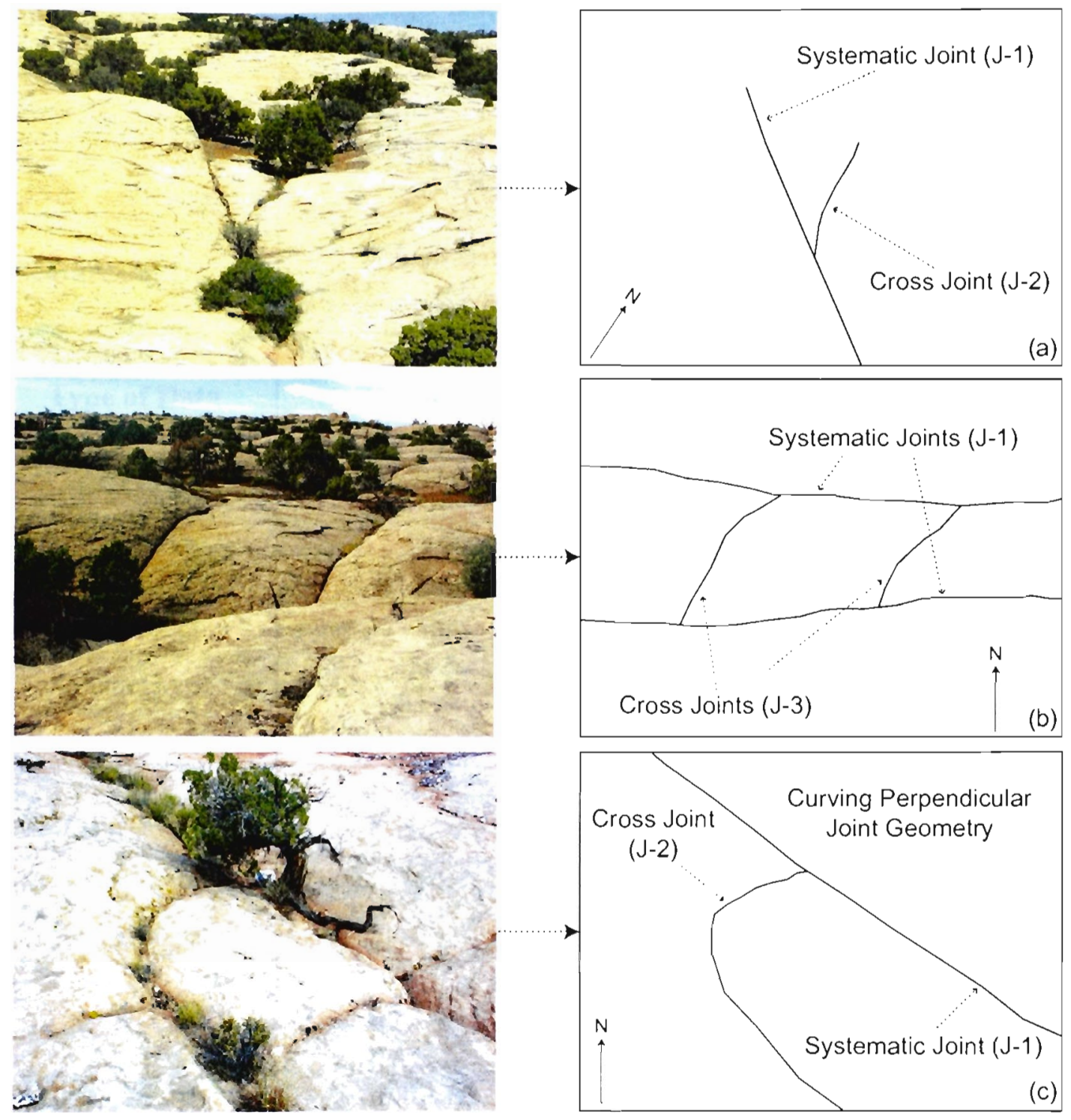

Figure 2.7 Field Photographs. (a) Relationship between systematic joint (J-1) and cross joint (J-2), (b) systematic joint (J-1) and cross joints (J-3), (c) curving perpendicular joint geometry. The Juniper trees are 8 to 10 feet in height. 
Table 2.1 Specifications of the remotely sensed images (after USGS, USDA).

\begin{tabular}{|c|c|c|}
\hline & $\begin{array}{l}\text { Digital Orthophoto } \\
\text { Quarter-Quadrangle } \\
\text { (DOQQ) }\end{array}$ & $\begin{array}{c}\text { True Color (Multispectral) } \\
\text { Aerial Photograph }\end{array}$ \\
\hline Source of Data & $\begin{array}{l}\text { EROS Data Center, } \\
\text { U.S. Geological Survey }\end{array}$ & $\begin{array}{l}\text { U.S. Department of Agriculture, } \\
\text { Farm Service Agency, } \\
\text { Aerial Photography Field Office }\end{array}$ \\
\hline Type of Data & $\begin{array}{l}\text { 256 Gray-Levels, } \\
\text { 8-Bit Binary Image }\end{array}$ & $\begin{array}{c}\mathrm{R}(1)-\mathrm{G}(2)-\mathrm{B}(3) \text { Composite } \\
\text { (Later the photograph was } \\
\text { scanned in } 25 \mu \mathrm{m} \text { resolution) }\end{array}$ \\
\hline Date of Acquisition & $4^{\text {th }}$ of July, 1997 & $26^{\text {th }}$ of June, 2002 \\
\hline Fight Height & $\begin{array}{c}12,192 \text { Meters } \\
\text { above Mean Terrain }\end{array}$ & 1,829 Meters \\
\hline Sensor Type & $\begin{array}{c}\text { Camera with } 152.4 \text { Millimeters } \\
\text { of Focal Length, } \\
\text { Sun Angle is } 30 \%, \\
\text { Camera Tilt is } 4^{\circ}\end{array}$ & $\begin{array}{c}\text { WILD RC10 } \\
\text { Airborne Camera } \\
\text { with } 153.65 \text { Millimeters } \\
\text { of Focal Length }\end{array}$ \\
\hline Film Type & $\begin{array}{l}240 \text { Millimeters } \\
\text { Panchromatic }(\mathrm{B} / \mathrm{W}) \\
\text { Negative Film }\end{array}$ & $\begin{array}{c}\text { (Natural) Color Negative Film } \\
\text { in } 229 \text { Millimeters x } 229 \\
\text { Millimeters Format }\end{array}$ \\
\hline Area Covered & $\begin{array}{c}\text { SW Quarter } \\
\text { (3.75" Lat. x 3.75" Long.) } \\
\text { of the } \\
\text { Digital Orthophoto Quadrangle } \\
\text { (7" Lat. x 7" Long.), } \\
\text { Mollie Hogans, Utah, } \\
\text { 8,047 Meters x 8,047 Meters }\end{array}$ & $\begin{array}{l}\text { 2,743 Meters x 2,743 Meters } \\
\text { (approx.) }\end{array}$ \\
\hline Photo Scale & $1: 40,000$ & $1: 12,000$ \\
\hline Spatial Resolution & 1 Meter & $\begin{array}{c}0.3 \text { Meter } \\
\text { (after rectification) }\end{array}$ \\
\hline Projection & $\begin{array}{l}\text { UTM, Zone-12, North, } \\
\text { GRS } 1980 \text { Spheroid, } \\
\text { NAD } 83 \text { Datum }\end{array}$ & $\begin{array}{c}\text { Unprojected } \\
\text { (when supplied) }\end{array}$ \\
\hline
\end{tabular}




\subsubsection{Digital Orthophoto Quarter Quadrangle (DOQQ)}

Digital Orthophoto Quadrangle (DOQ) is a computer generated image of an aerial photograph in which displacements caused by terrain relief and camera tilts have been removed (USGS, 2000). Further, a DOQ combines the image characteristics of a photograph with the geometric qualities of a map. A panchromatic (B/W) aerial photograph in the form of a Digital Orthophoto Quarter Quadrangle (DOQQ) produced by the U.S.Geological Survey was used as one of the source images. The DOQQ used for this study (MOLLIE_HOGANS_UT_SW) is in gray-scale digital image format with one meter spatial resolution. The predefined projection type is UTM, Zone-12, North; GRS 1980 spheroid and NAD 83 datum. Refer to Table 2.1 for detailed specifications of the DOQQ.

\subsubsection{True color aerial photograph, and preprocessing of the image}

A true color aerial photograph (6-26-02, USDA-NPS, 12, ARCH, 902-48) produced by the U.S. Department of Agriculture was used as another source of data. The photograph was scanned in 25 micrometer resolution (the equivalent horizontal ground resolution is 0.3 meter) by USDA and was supplied in digital format. The multispectral image has three bands (USDA, 2002; Table 2.1). It lacks projection information, and hence was devoid of any scaling or resolution parameters when obtained. The color aerial photograph was transformed into real world coordinates by registering it to the DOQQ to generate a base map and define an area of interest. 
Rectification is the process whereby the geometry of an image is made

planimetric (Jensen, 2000, 2005). Geocoding is the process of rectification of an image to a particular map projection and cell size (ERDAS, 2002). The following sections describe the geocoding procedure applied to the unprojected image of the color aerial photograph in order to rectify it in the reference frame of the DOQQ using ERDAS Imagine software. Registration is a process of aligning two or more maps or images so that equivalent geographic coordinates coincide (Kennedy, 2001; ERDAS, 2002). It is performed by the selection of common ground control points (GCPs) from two images and then linking GCPs of one image to the GCPs of the other. To facilitate registration of the unprojected color aerial photograph in the reference frame of the DOQQ, 475 control points from both images were selected and matched using ERDAS Imagine software. Rubber sheeting, also known as warping or elastic transformation is defined as the mathematical stretching or shrinking of a portion of an image in order to align its coordinates with known control points (Kennedy, 2001; ERDAS, 2002). The procedure is based on triangle-based finite element analysis (ERDAS, 2002), and this nonlinear transformation procedure was applied to rectify the color aerial photograph using ERDAS Imagine software. Resampling is defined as the reduction of the file size of an image by representing a group of pixels with a single pixel. A resampled image appears coarser than the image from which it is taken, because it uses less information to represent the same geographic extent (Kennedy, 2001). Resampling is used while transforming a raster image to a particular scale or projection. Nearest neighbor assignment is a technique for resampling raster data in which the value of each cell in an output raster is calculated using the value of the nearest cell in an input grid (Kennedy, 2001). In order to rectify the 
color aerial photograph, nearest neighbor resampling method was employed. The output of geocoding is the rectified color aerial photograph (Fig. 2.8b), which has the same coordinate system as the DOQQ (Fig. 2.8a). The spatial resolution of the rectified color aerial photograph is 0.3 meter, which is similar to the $25 \mu \mathrm{m}$ scanning resolution of the color aerial photograph.

The study area (Figs. 2.8c, 2.9) was defined from the rectified color aerial photograph (Fig. 2.8b). Subsequently, the lithological contacts were traced from the color aerial photograph of the study area to prepare a base map of the study area (Fig. 2.10). The locations of the GPS recordings collected during the field survey were plotted on the base map within the GIS environment. The descriptions of the ground truth GPS locations shown in Figure 2.10 are given in Table 4.2 under the chapter on landcover classification. Outcrops of the Slickrock Member, Tidwell Member, deposits of Recent Alluvium, and a region of substantially eroded Moab Member were excluded from the base map to define an area of interest (white area in Figure 2.10). The area of interest is characterized by the outcrops of mega-scale fractures developed in the Moab Member of the Curtis Formation. 


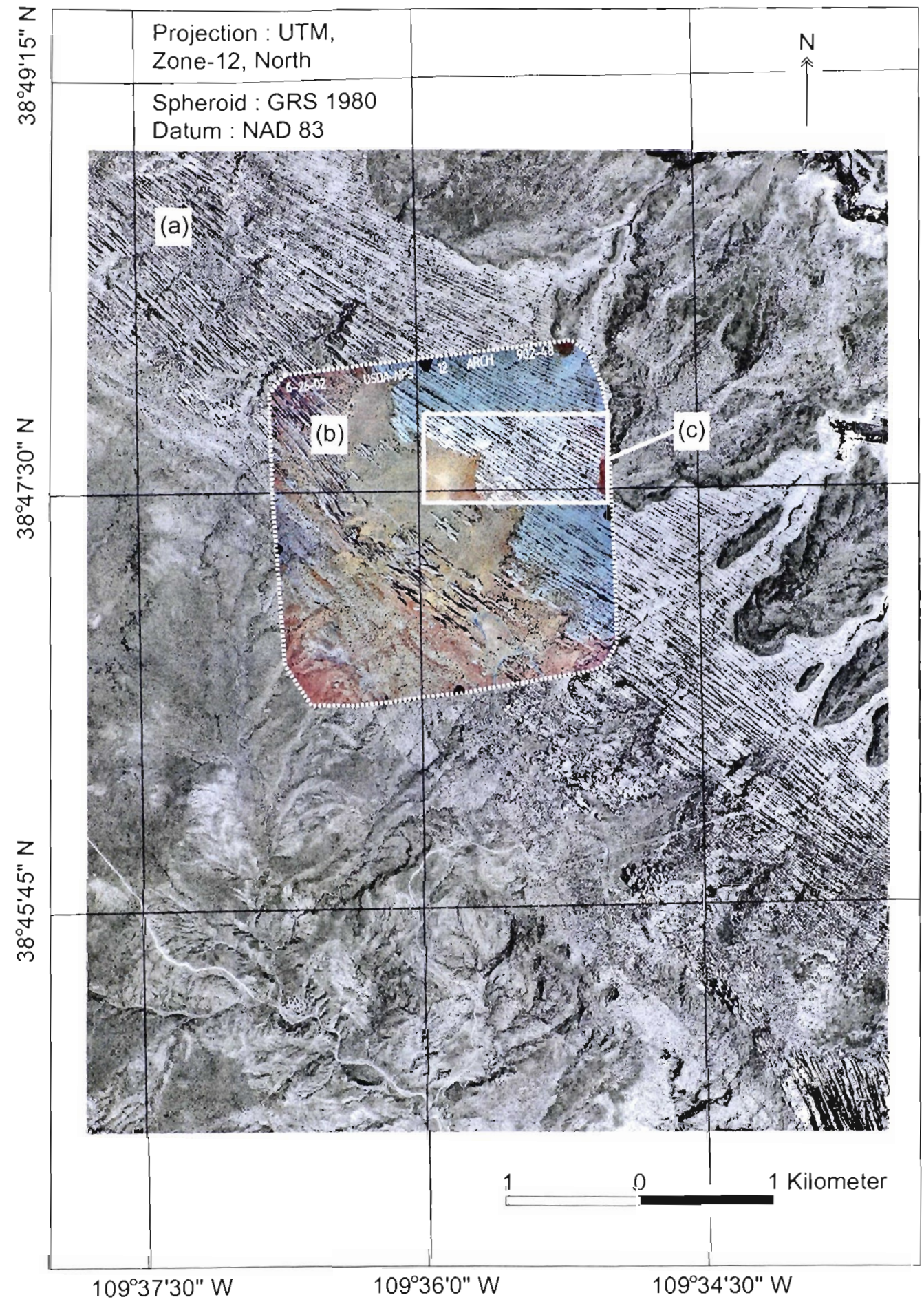

Figure 2.8 Rectified color aerial photograph superimposed on the DOQQ. (a) DOQQ (source : USGS), (b) rectified color aerial photograph (source : USDA), and (c) the study area. 


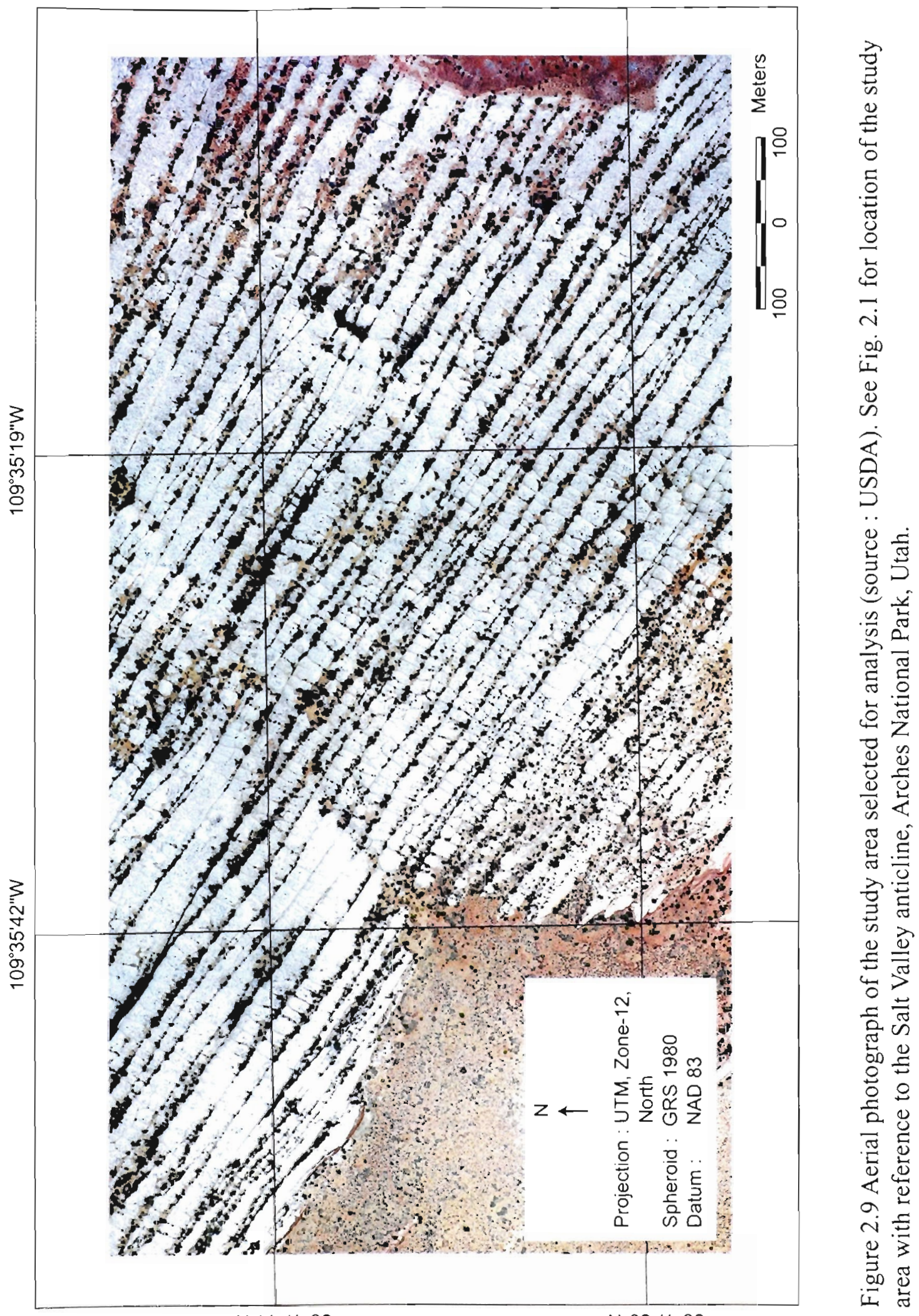




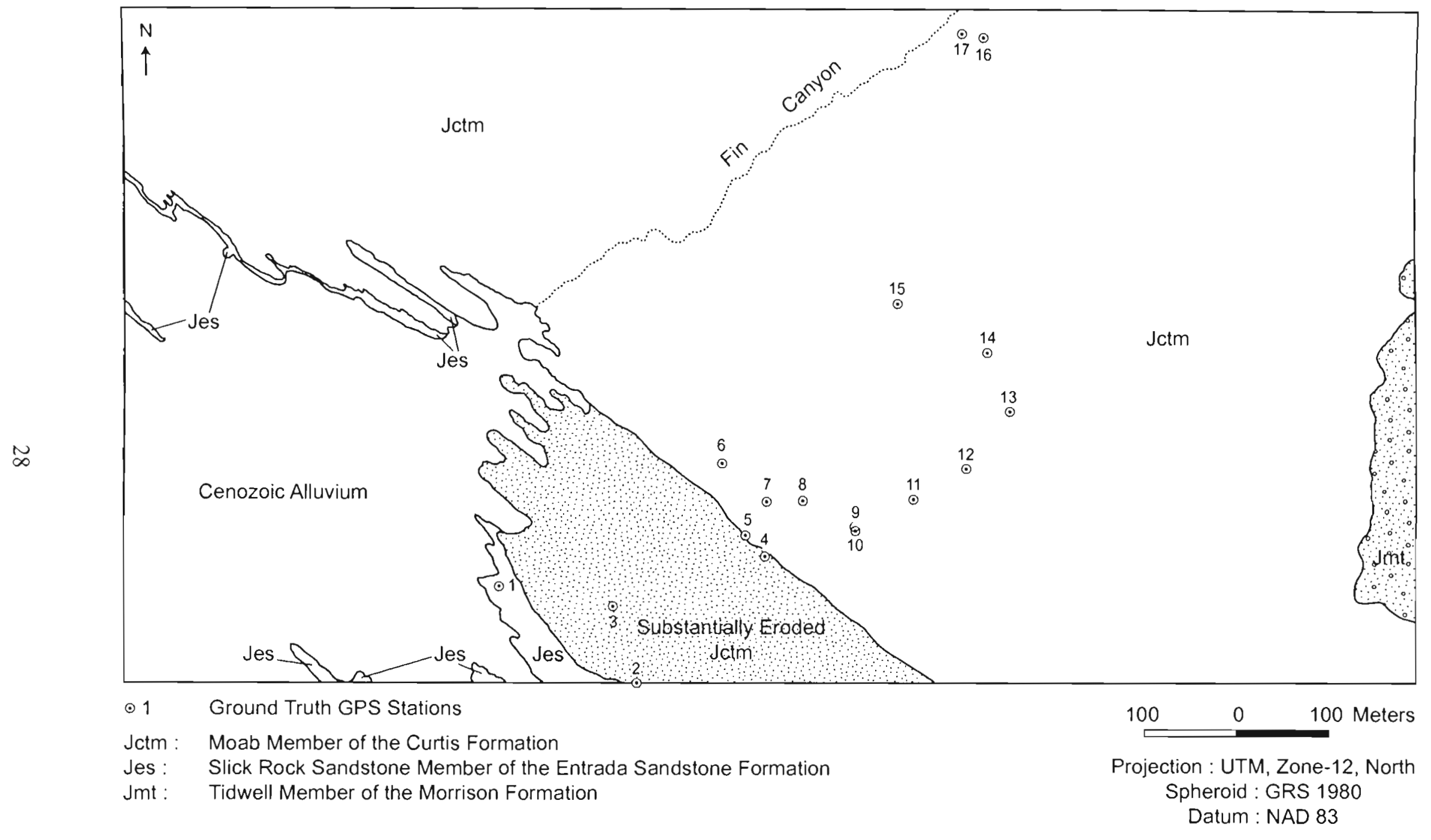

Figure 2.10 Geologic map of the study area, as traced from the color aerial photograph in Fig. 2.9. White area on the map represents the area of interest. 


\section{Chapter 3}

\section{CHARACTERIZATION OF FRACTURE NETWORK}

\subsection{Ground truthing and the field observations}

Ground truthing and field surveys were carried out during the month of July, 2004 in Arches National Park, Utah. During the site investigation, different fracture sets and fracture geometries were studied on outcrops of the Moab Member of the Curtis Formation. Four distinct mega-scale fracture sets (i.e. visible from aerial photographs) are present within the study area (Fig. 3.1), including one set of systematic joints (J-1 set), two sets of cross joints (J-2 and J-3 sets) and a fourth set of polygonal joints (J-4 set). The cross joints (J-2 set and J-3 set) and the polygonal joints (J-4 set) are contained within the boundaries of the systematic joints of the J-1 set. Further, at places, the second set of cross joints (J-3 set) and the polygonal joints (J-4 set) are confined within the boundaries of the systematic joints ( J-1 set) and the first set of cross joints (J-2 set). When a younger cross joint (J-2) approached an older systematic joint (J-1), two types of joint geometries were observed (Figs. 2.6 and 2.7a,c). The younger cross joint (J-2) either curved parallel, or curved perpendicular to the older systematic joint (J-1), as noted by Dyer (1988).

The systematic joints (J-1 set) are the longest. Then in order of decreasing size are the cross joints of the J-2 and the J-3 sets. The polygonal joints (J-4 set) are the smallest in length. The apertures of the systematic joints (J-1 set) and cross joints of the J-2 set are wide and hence they appear as fissures (Fig. 3.1a). Within the fissures, Juniper and Pine trees are growing. 


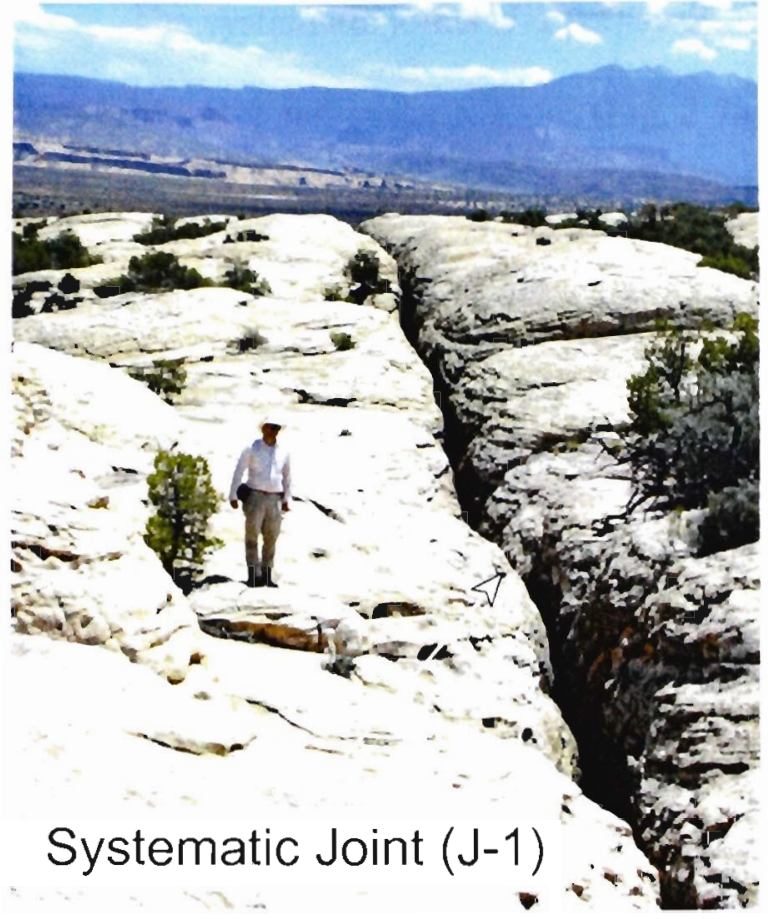

(a)

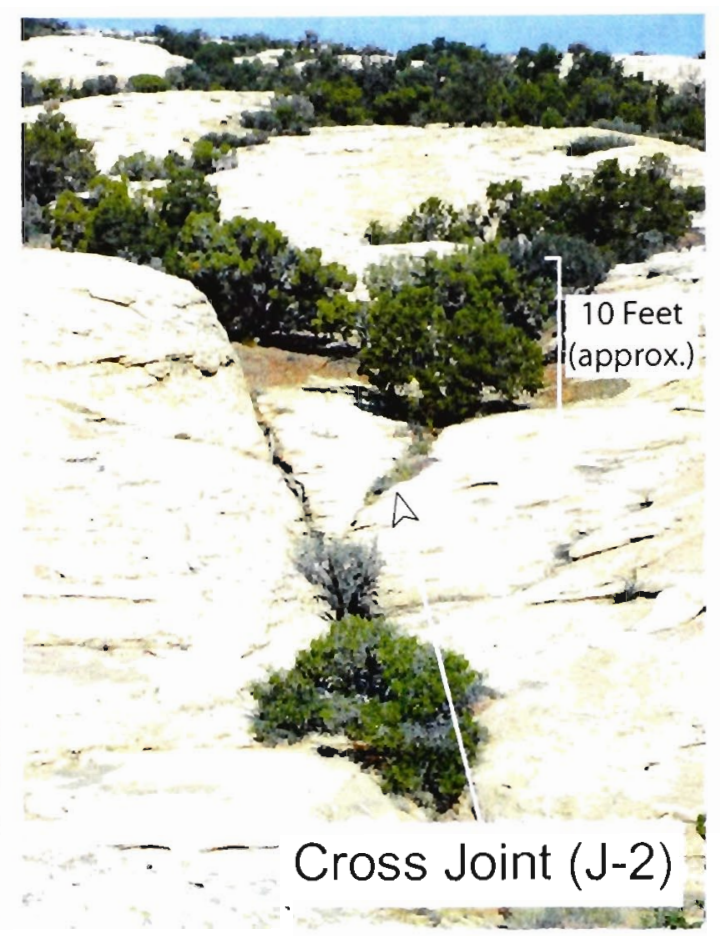

(b)
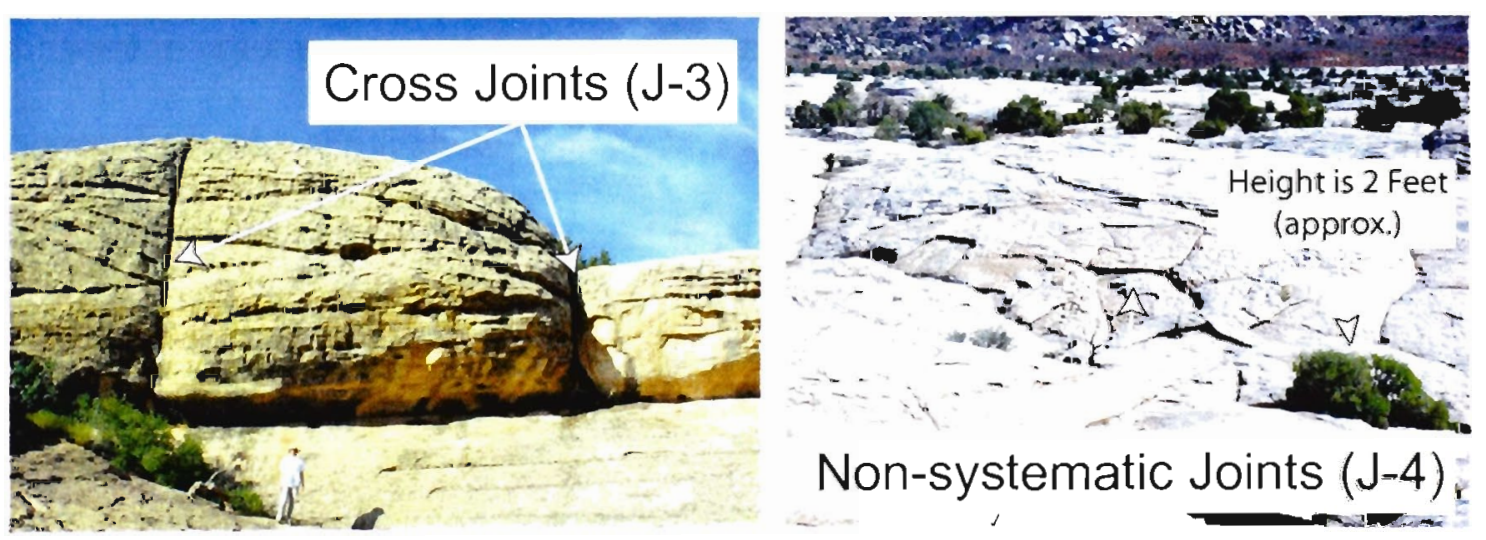

Non-systematic Joints $(\mathrm{J}-4)$

(c)

(d)

Figure 3.1 Field photographs of the four different sets of joints. (a) Systematic joint $(\mathrm{J}-1)$, (b) cross joint (J-2) terminating against a systematic joint, (c) cross joints (J-3), and (d) non-systematic polygonal joints (J-4). 
The systematic joints (J-1 set) strike WNW-ESE (Fig. 2.7a) and the first set of cross joints (J-2 set) strike NW-SE (Fig. 2.7a). The J-3 set of cross joints strikes NNESSW (Fig. 2.7b), whereas the J-4 set of polygonal joints have varied orientation (Fig. 3.1d). All the fractures within the study area are sub-vertical to vertical. The spacing between the systematic joints ( $\mathrm{J}-1$ set) and the cross joints of $\mathrm{J}-3$ set are relatively uniform (Fig. 2.7b), whereas the spacing between the cross joints of the J-2 set is irregular.

\subsection{Digitization of the fracture traces and creation of a fracture geodatabase}

For geological studies, fracture traces can be mapped from digital photographs (Ehlen et al., 1995). In this study, fracture traces were digitized in ERDAS Imagine software in order to generate fracture trace maps. The digitization was carried out over the rectified color aerial photograph of the study area (Fig. 2.9). Individual fracture sets were digitized separately. The digitized fracture traces were cleaned and built in the ERDAS Imagine software to define topology (Davis, 2001; ERDAS, 2002), before importing them into the GIS software. Then, the individual fracture sets were combined to generate a fracture network map. Finally, the individual fracture maps (Fig. 3.2) and the fracture network map (Fig. 3.3) were imported in the ArcView GIS environment as a geodatabase consisting of all of the fractures. 

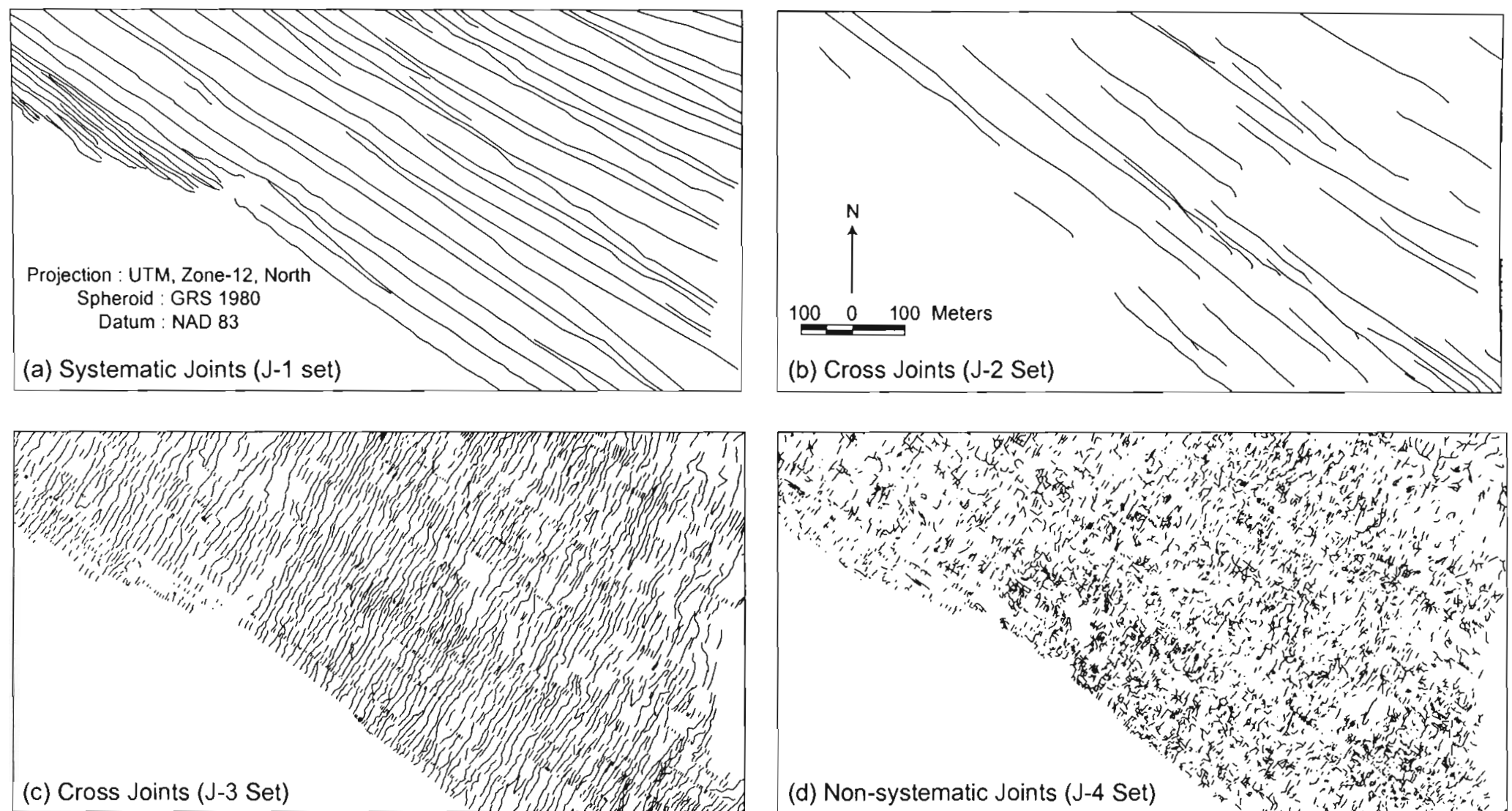

Figure 3.2 Spatial distribution of joints. (a) Systematic joints (J-1 set), (b) cross joints (J-2 set), (c) cross joints (J-3 set), and (d) non-systematic polygonal joints (J-4 set). 


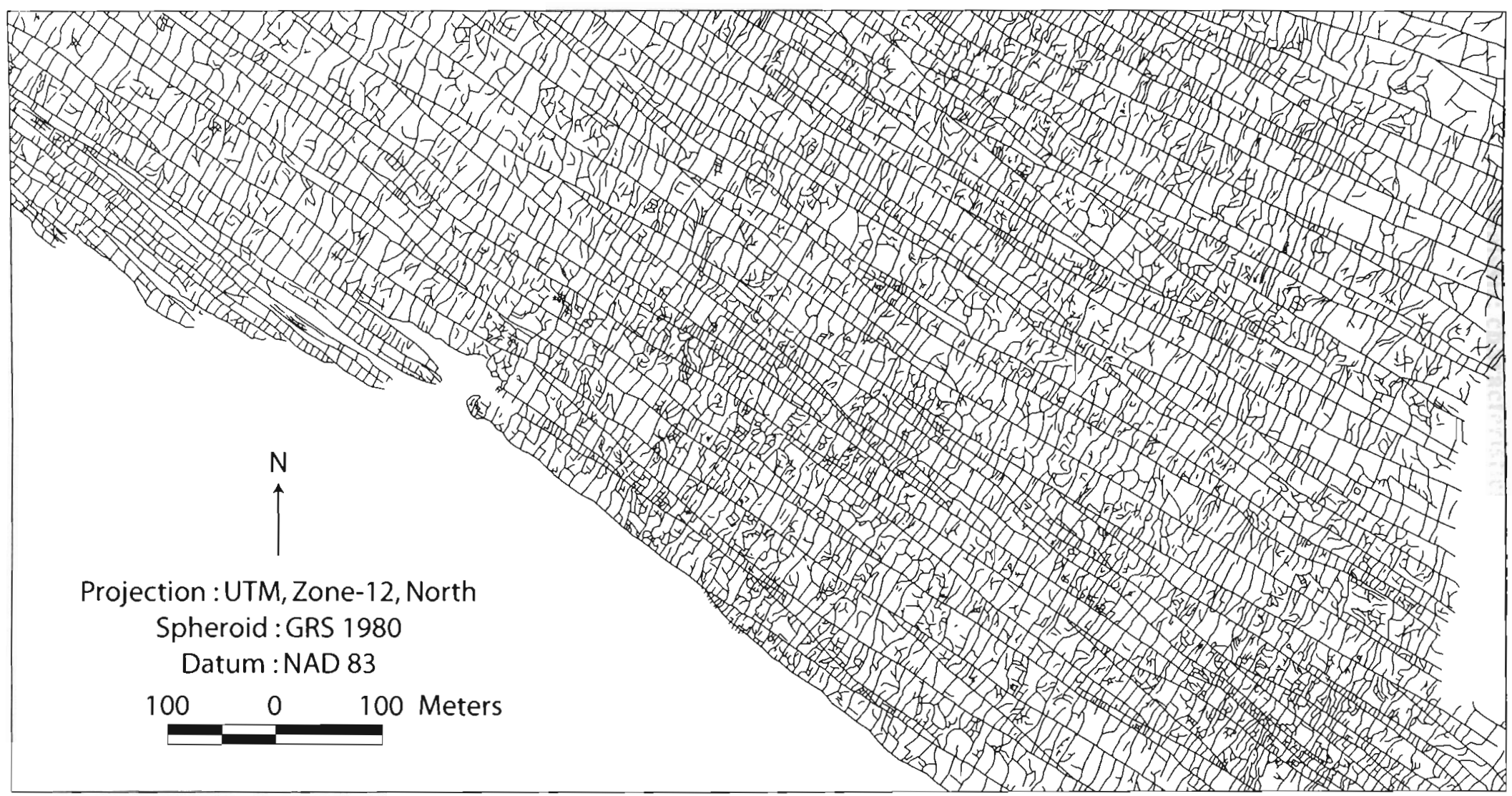

Figure 3.3 Fracture trace map of the entire fracture network as digitized from the aerial photograph. 


\subsection{Vector analysis: characteristics of the fracture populations}

Fracture traces, stored as arcs (Zeiler, 1999; Longley et al., 2001), were imported into the GIS database in vector data format. Vector analysis was carried out for the determination of fracture length, fracture orientation and fracture spacing.

\subsubsection{Determination of fracture trace lengths and fracture orientations}

Fracture length and orientation parameters can be computed as traces exposed on the outcrop surface and mapped from the aerial photograph (La Pointe and Hudson, 1985; Post et al., 2001; Carr, 2002). Fracture length characterizes fracture size and can be utilized in establishing scaling relationships (Odling, 1992, 1997; Chilès and Marsily, 1993; Odling et al., 1999; Bonnet et al., 2001; Gillespie et al., 2001; La Pointe, 2002). Using the 'XTools' extension of ArcView GIS software, the fracture length of all fractures within the fracture network were calculated. The fracture sizes of individual fracture populations (Table 3.1) are presented in histograms (Figs. 3.4a, 3.5a, 3.6a, 3.7a). Further, with the aid of the 'Distance and Azimuth Tools' extension of the software, the azimuths of the fracture traces were computed, and incorporated within the geodatabase. The average fracture orientations of individual fracture sets were calculated (Figs. 3.4b, $3.5 \mathrm{~b}, 3.6 \mathrm{~b}, 3.7 \mathrm{~b})$. The frequency distribution of joint length and number of joints are shown in Figure 3.8. There are biases in the fracture lengths distributions due to cell resolution, and edge effects due to the extent of the study area. 


\begin{tabular}{|c|c|c|c|c|c|c|}
\hline 吾 & $\frac{n}{\frac{n}{2}}$ & 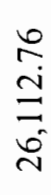 & $\begin{array}{l}\bar{b} \\
0 \\
\text { ปे } \\
0\end{array}$ & 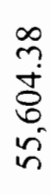 & $\begin{array}{l}\overline{7} \\
\dot{0} \\
\dot{0} \\
\dot{0} \\
\dot{n}\end{array}$ & 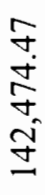 \\
\hline 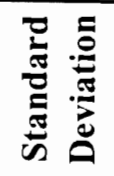 & $\frac{0}{20}$ & ঙ̊ & $\frac{m}{2}$ & $\frac{n}{0}$ & $\underset{\sim}{\stackrel{\nabla}{*}}$ & $\frac{\mathfrak{n}}{\mathfrak{r}}$ \\
\hline 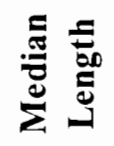 & $\frac{0}{\frac{0}{0}}$ & $\begin{array}{l}\stackrel{\sim}{\sim} \\
\infty \\
m\end{array}$ & $\frac{0}{2}$ & \begin{tabular}{l}
\multirow{n}{n}{} \\
0
\end{tabular} & $\begin{array}{l}\underset{\forall}{*} \\
\dot{8}\end{array}$ & $\frac{\Delta}{r}$ \\
\hline 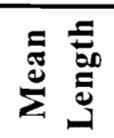 & 㐫 & 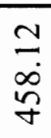 & $\frac{\Xi}{\dot{n}}$ & $\begin{array}{l}\text { N } \\
\infty\end{array}$ & $\begin{array}{l}\infty \\
\stackrel{n}{0} \\
\end{array}$ & $\stackrel{\infty}{\stackrel{m}{\sim}}$ \\
\hline 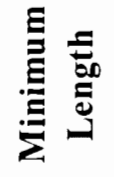 & $\frac{n}{\frac{0}{0}}$ & $\stackrel{\check{r}}{\dddot{m}}$ & $\begin{array}{l}\bar{a} \\
\underline{n}\end{array}$ & $\stackrel{8}{8}$ & $\begin{array}{l}\infty \\
\infty \\
\dot{0}\end{array}$ & $\begin{array}{l}\infty \\
\stackrel{\infty}{0} \\
\stackrel{0}{0}\end{array}$ \\
\hline 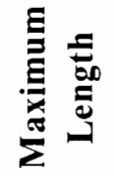 & $\frac{n}{\frac{0}{0}}$ & $\begin{array}{l}0 \\
\infty \\
\vdots \\
=\end{array}$ & $\begin{array}{l}\tilde{a} \\
\stackrel{\sim}{+} \\
\infty\end{array}$ & $\stackrel{i}{r}$ & ñ & $\begin{array}{l}\infty \\
\infty \\
\stackrel{0}{2}\end{array}$ \\
\hline 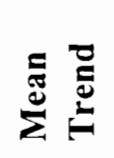 & 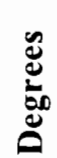 & 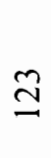 & $\stackrel{\infty}{\sim}$ & $\bar{m}$ & ภิ & I \\
\hline 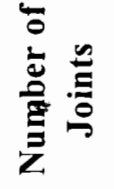 & Z & in & $\bar{\nabla}$ & $\underset{m}{\mathfrak{O}}$ & $\frac{10}{6}$ & $\begin{array}{l}\circ \\
\infty \\
0\end{array}$ \\
\hline & & $\frac{\bar{D}}{\dot{D}}$ & $\begin{array}{l}\stackrel{\mathscr{D}}{W} \\
\stackrel{+}{\longrightarrow}\end{array}$ & $\stackrel{\vec{\Delta}}{\stackrel{\leftrightarrow}{s}}$ & 岕 & 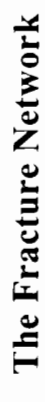 \\
\hline
\end{tabular}


(a) Frequency Distribution of the Lengths of Systematic Joints (J-1)

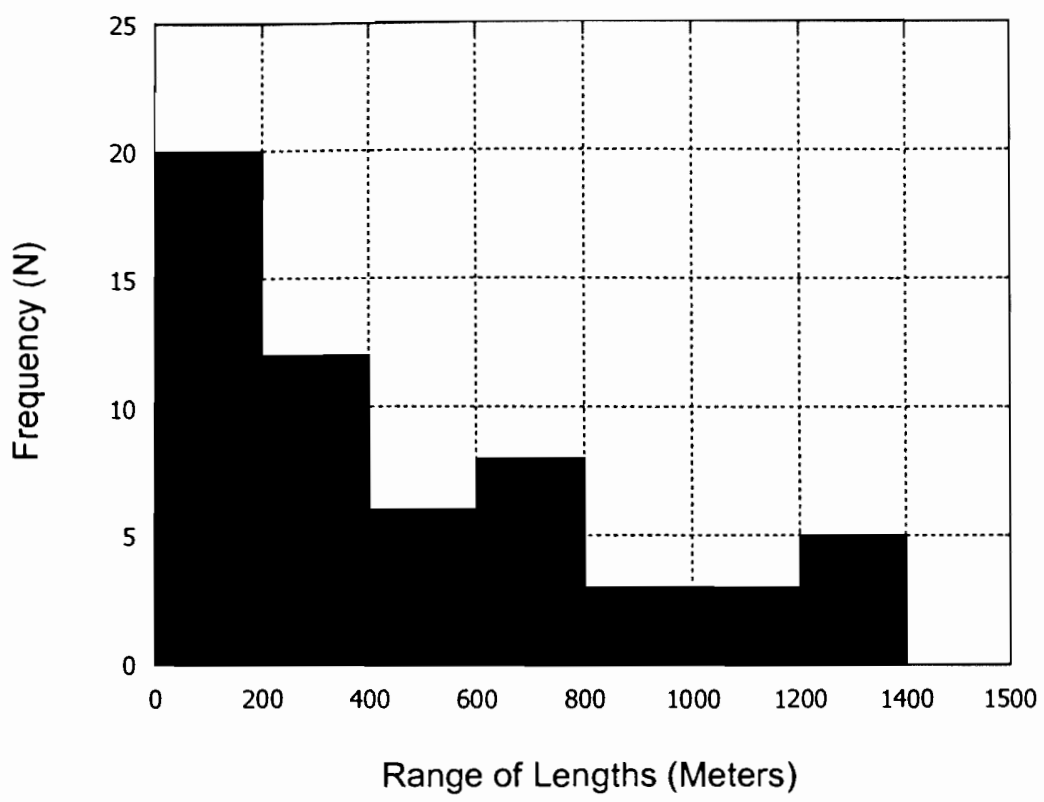

(b)

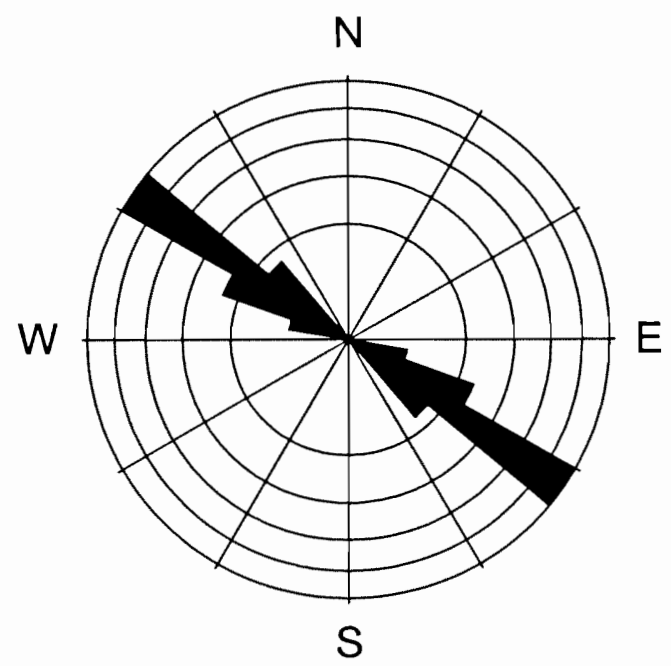

Total No. of Joints : 57

Mean Trend : $123^{\circ}$

Figure 3.4 Characteristics of the population of the systematic (J-1) joint set. (a) Frequency distribution of length, and (b) rose diagram of joints azimuths, class size is 20 . 
(a)

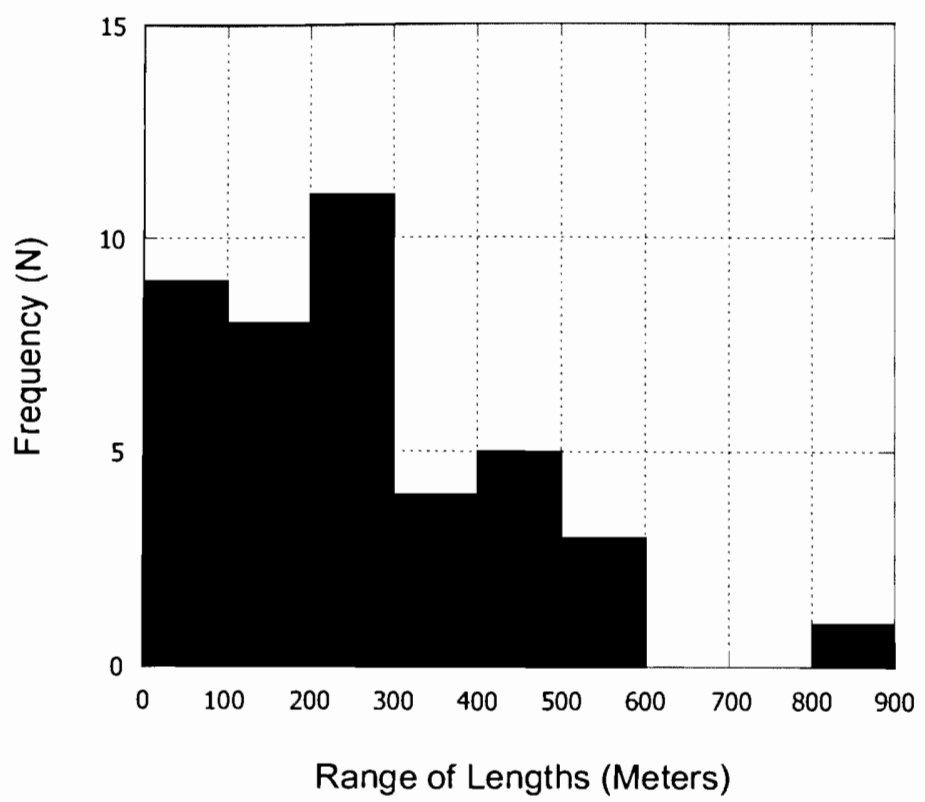

(b)

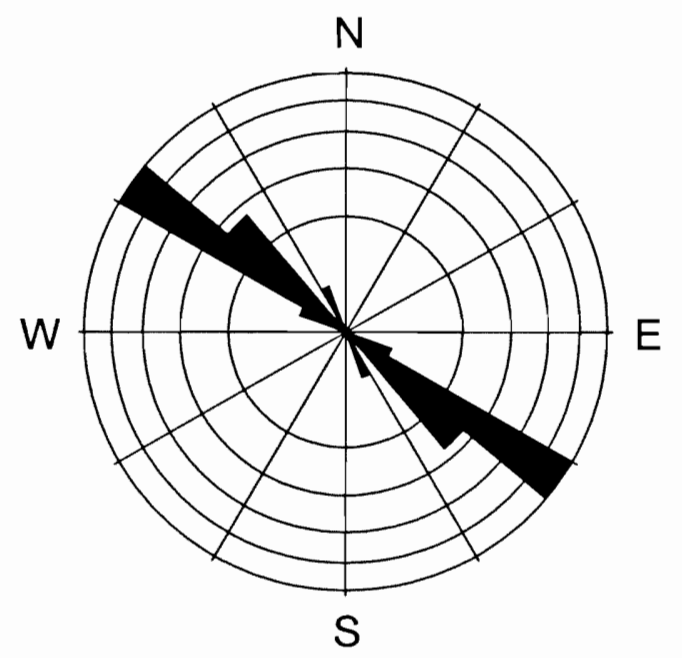

Total No. of Joints : 41

Mean Trend : $128^{\circ}$

Figure 3.5 Characteristics of the population of the cross (J-2) joint set. (a) Frequency distribution of length, and (b) rose diagram of joints azimuths, class size is 20 . 
(a) Frequency distribution of the Lengths of Cross Joints $(\mathrm{J}-3)$

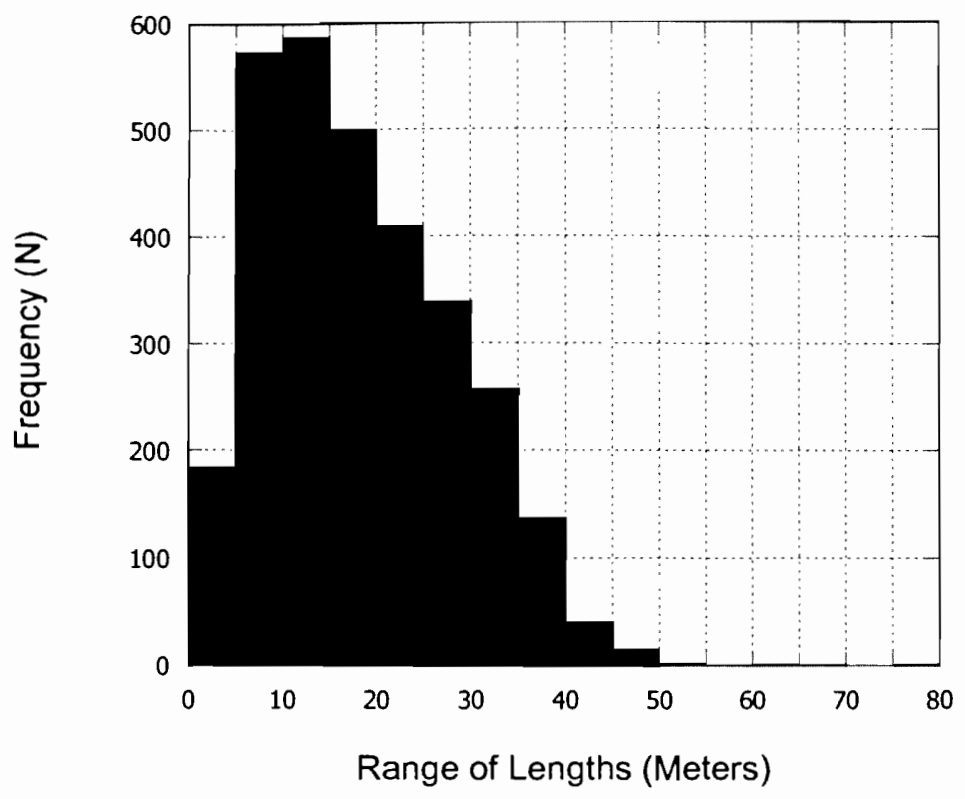

(b)

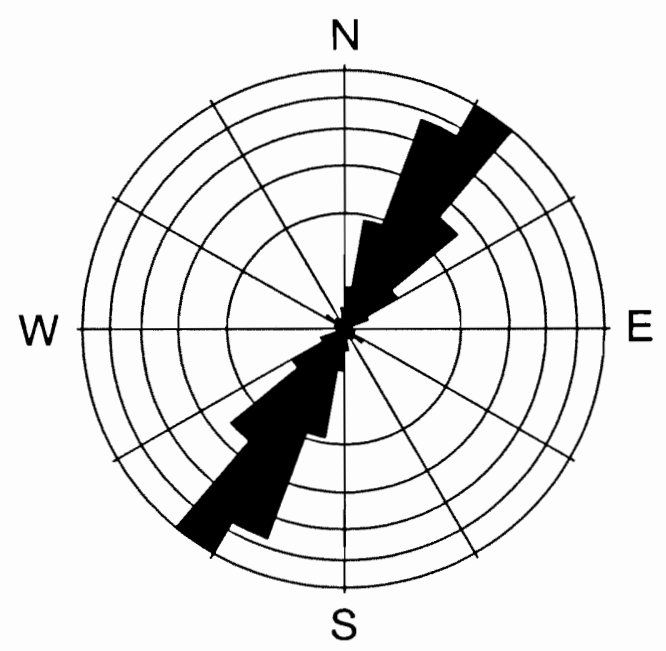

Total No. of Joints : 3,045

Mean Trend : $31^{\circ}$

Figure 3.6 Characteristics of the population of the cross (J-3) joint set. (a) Frequency distribution of length, and (b) rose diagram of joints azimuths, class size is 20 . 
(a) Frequency Distribution of the Lengths of Non-systematic Joints ( $\mathrm{J}-4)$

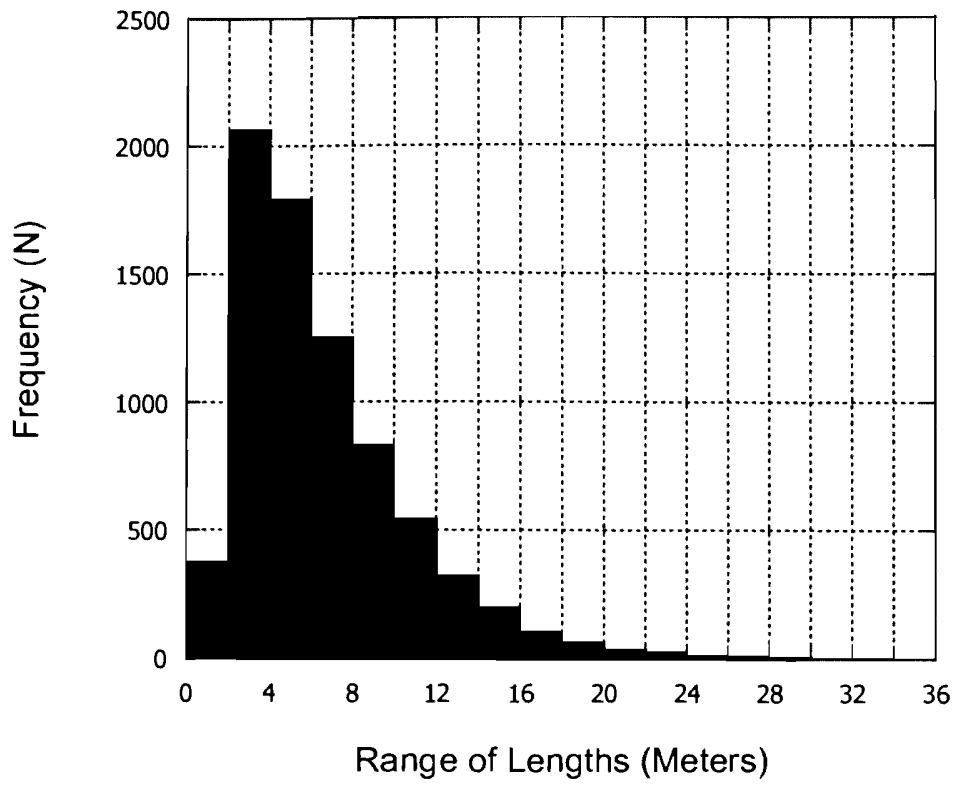

(b)

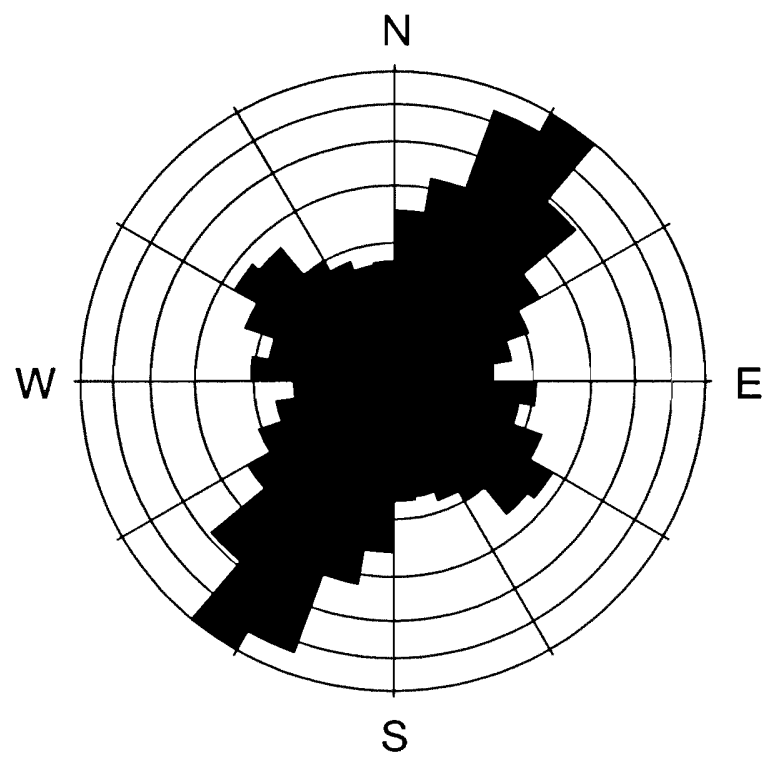

Total No. of Joints : 7,667 Mean Trend : $29^{\circ}$

Figure 3.7 Characteristics of the population of the non-systematic (J-4) joint set. (a) Frequency distribution of length, and (b) rose diagram of joints azimuths, class size is 20 . 


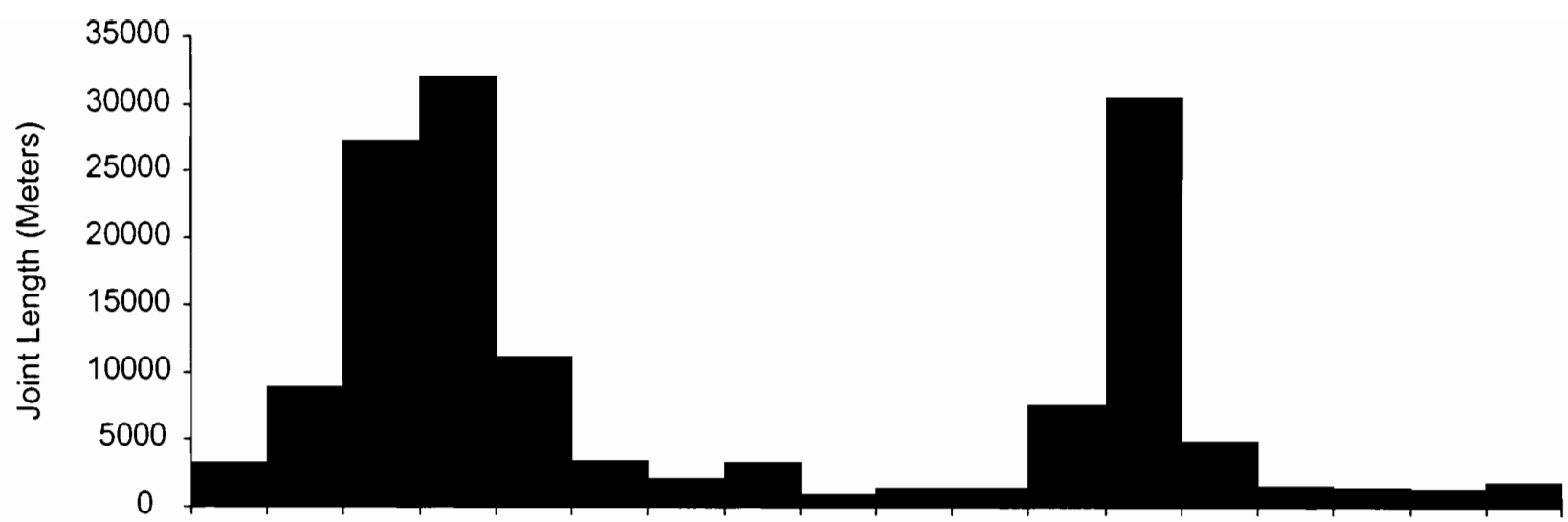

(a)

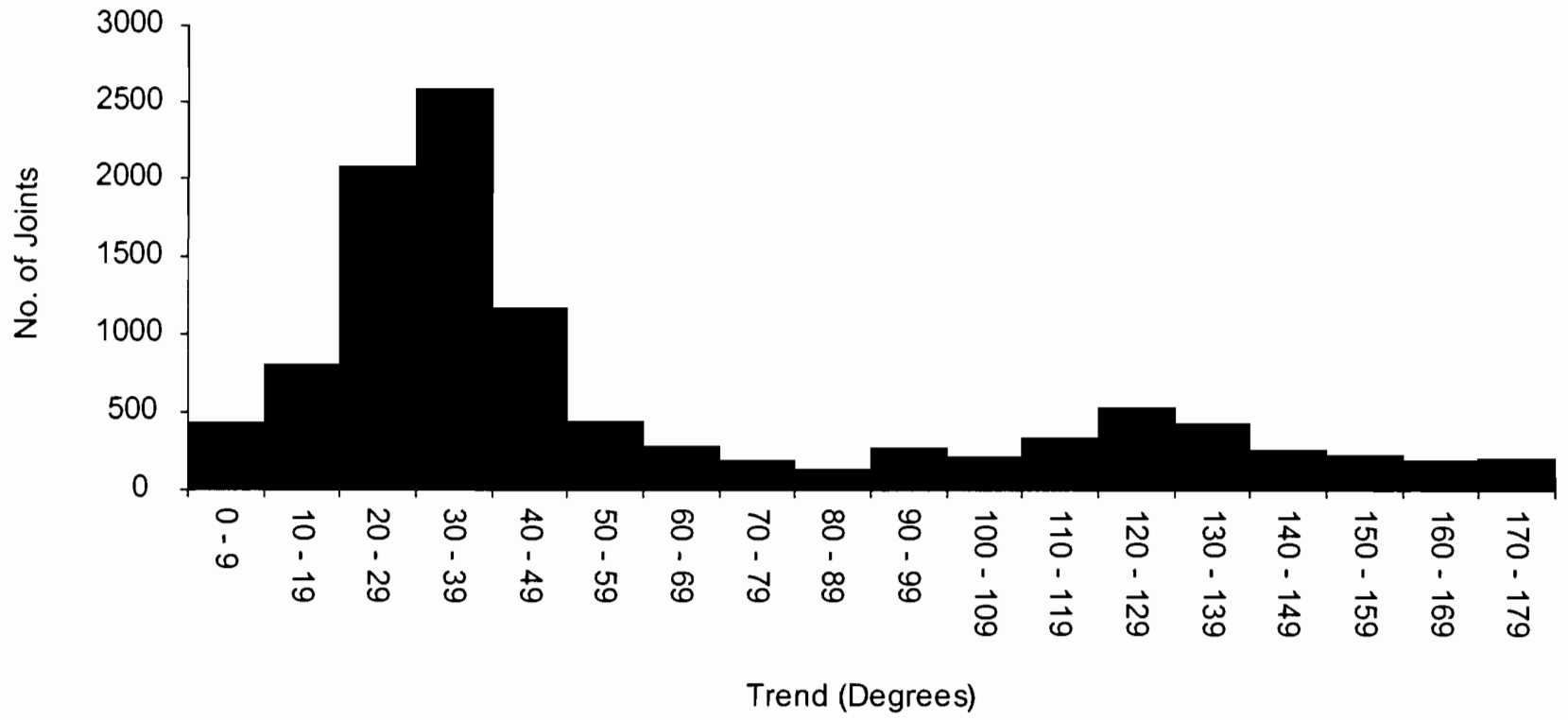

Figure 3.8 Frequency distribution of (a) cumulative joint length, and (b) number of joints within the entire fracture network. 
The four sets of joints show a wide range of variation in fracture sizes (Table 3.1). The largest fracture in the fracture network is three orders of magnitude larger than the smallest fracture within the network. The fracture lengths of all the sets of joints show positively skewed frequency distribution (Figs. 3.4a, 3.5a, 3.6a, 3.7a). The J-1 set of systematic joints trend WNW-ESE (Fig. 3.4b), which is sub-parallel to the trend of the regional fold axis of the Salt Valley anticline. The J-2 set of cross joints trend nearly NW-SE (Fig. 3.5b). The difference between the mean trends of both of the joint sets is $5^{\circ}$. The orientations of the J-2 joints are similar to that of the J-1 joints. The J-3 set of cross joints trend NNE-SSW (Fig. 3.6b), which is perpendicular to the trend of the systematic joint set, and the trend of the regional fold axis. The J-4 set of non-systematic polygonal joints shows a wide range of orientations (Fig. 3.7b). Further, the orientations of the J-4 set of joints are not random, and show a strong NE-SW trend sub-parallel to the $\mathrm{J}-3$ set of cross joints. This implies that the J-4 set of non-systematic joints started developing nearly parallel to the J-3 set cross joints, but the propagation was inhibited by the changes in local stress field, which might have caused due to near surface unloading.

\subsubsection{Fracture spacing measurements}

Fracture spacing is a significant parameter that illustrates the distribution of joints along a line (Priest and Hudson, 1976; Huang and Angelier, 1989; Rives et al., 1992; Gillespie et al., 1993, 1999; Gross, 1993; Gross et al., 1995; Becker and Gross, 1996; Ruf et al., 1998). It is used to quantify 1-D (Narr and Suppe, 1991; Gross and Engelder, 1995; Peacock et al., 2003) and 2-D fracture distributions (Wu and Pollard, 1995; Renshaw, 
1997). The spacing statistics obtained from 1-D scan lines (Fig. 3.9) provide valuable information regarding fracture clustering.

Fracture spacing was determined using the ArcView GIS software. Onedimensional scan lines were drawn perpendicular to the mean orientation of the fracture traces for the individual fracture sets. For each fracture set, five scan lines were drawn. The scan lines drawn for each fracture set are equally spaced. The spacing between the scan lines for the systematic joints of the $\mathrm{J}-1$ set and the cross joints of the J-2 set is 300 meters, whereas the spacing between the scan lines for the cross joints of the J-3 set and the polygonal joints of J-4 set is 150 meters (Fig. 3.10).

Using the 'Themes Intersection to Points' extension of the ArcView GIS software, the intersection points between the scan lines and the fracture traces were generated. Subsequently, the 'Point and Polyline Tools' extension of the GIS software was used to split the scan lines along the intersection points. The lengths of each segment of the split scan lines represent fracture spacing for the adjacent pairs of fractures of a particular set. The lengths of the split segments of the scan lines were computed using 'XTools' extension of the GIS software to obtain the fracture spacing measurements. The fracture spacing statistics were calculated (Table 3.2) and plotted as histograms (Fig. $3.11)$.

The 1-D scan lines drawn for fracture spacing measurements were equally spaced, and the spacing between scan lines drawn to measure fracture spacing for a particular set of joints is arbitrarily determined by visual inspection to encompass the entire area of interest (Fig. 3.10). The spacing distributions of the joints are positively skewed (Fig.3.11). The J-2 set of joints show greater median spacing, whereas the J-3 and J-4 sets 


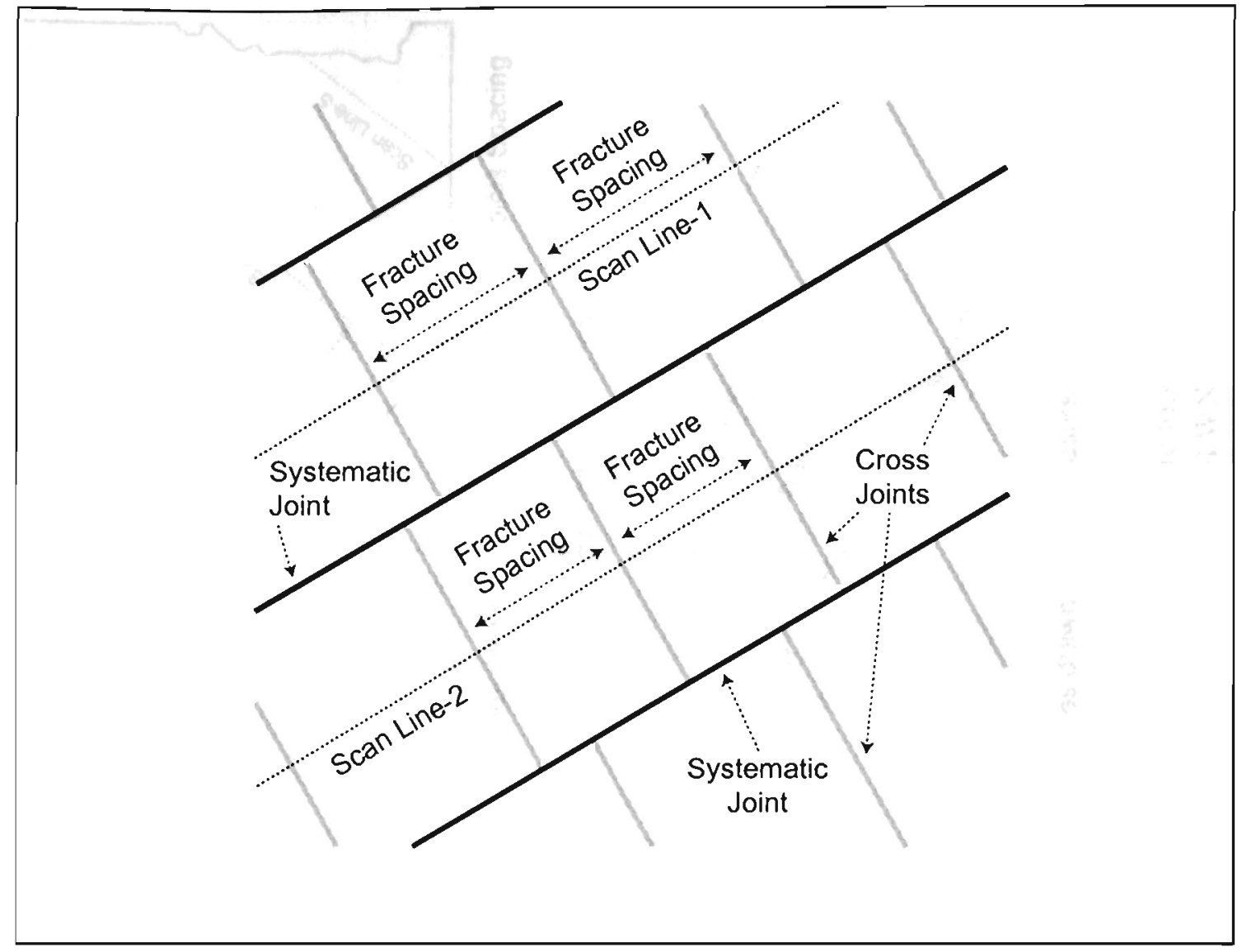

Figure 3.9 Schematic illustration showing the principle for the measurement of cross joint spacing using 1-D scan lines. 


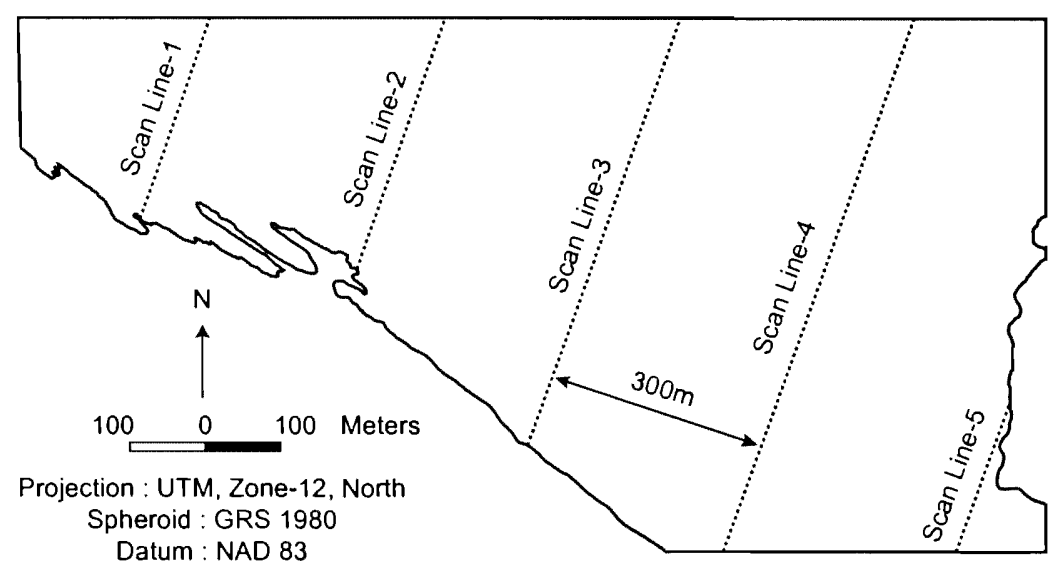

(a) Scan Lines drawn for the Measurement of J-1 Joints Spacing.

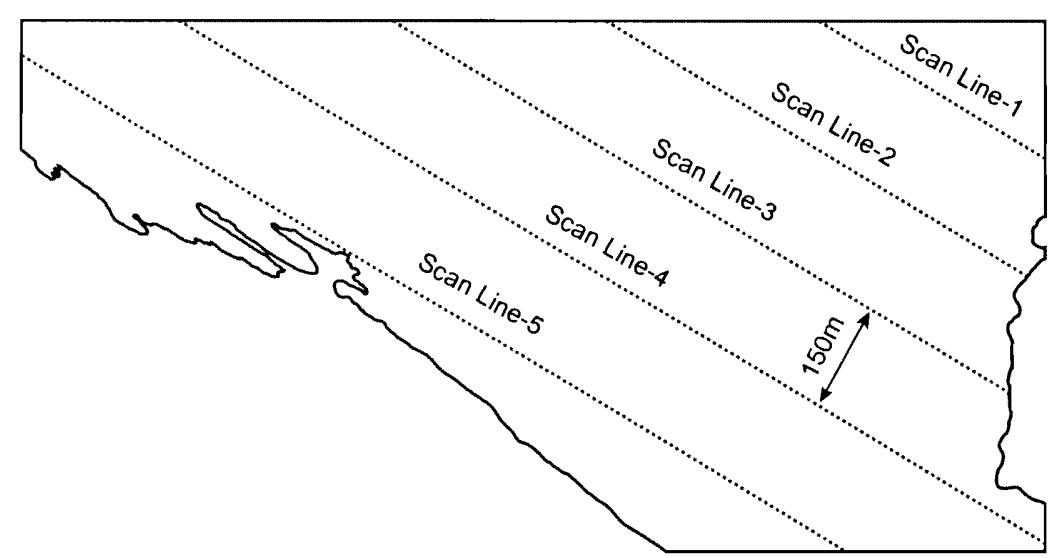

(c) Scan Lines drawn for the Measurement of J-3 Joints Spacing.

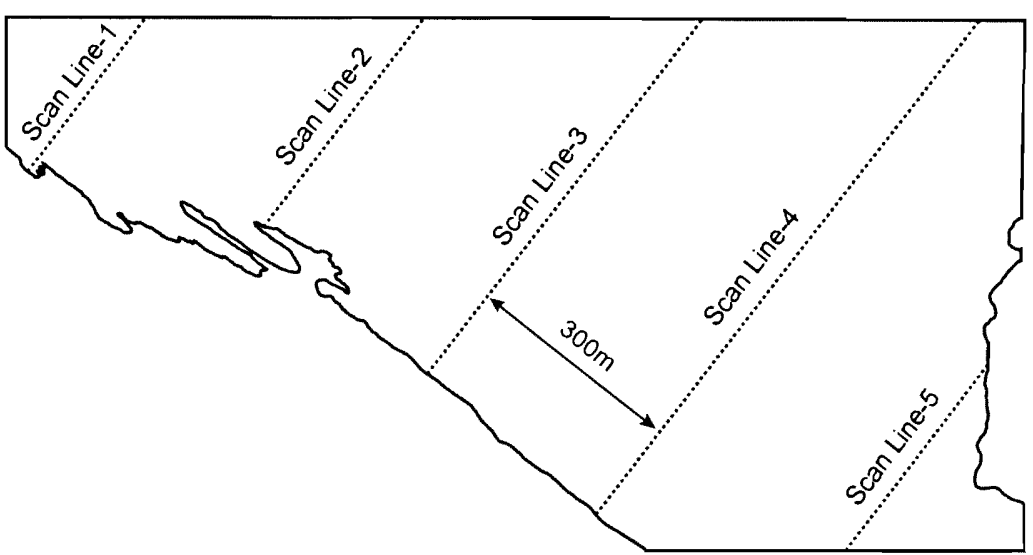

(b) Scan Lines drawn for the Measurement of J-2 Joints Spacing.

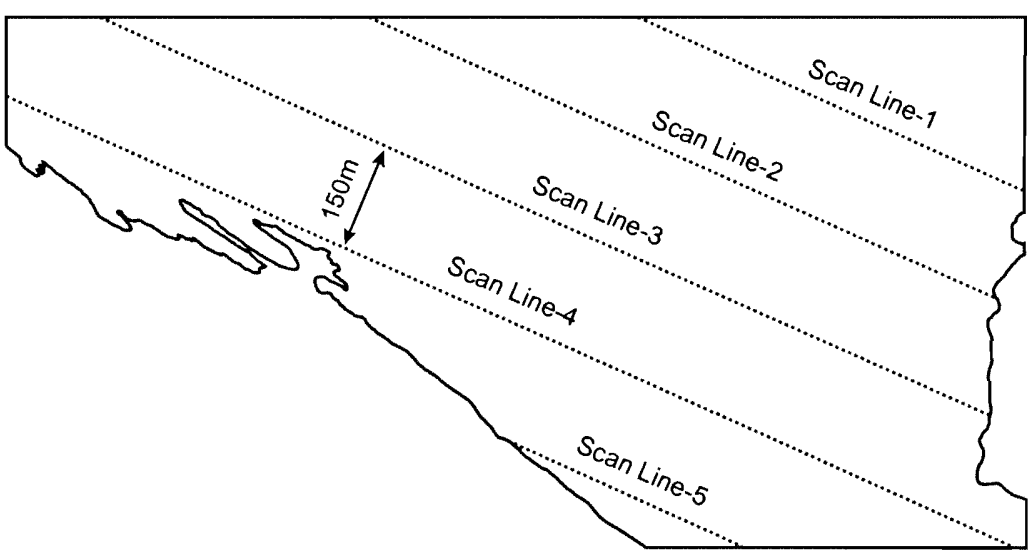

(d) Scan Lines drawn for the Measurement of J-4 Joints Spacing.

Figure 3.10 Scan lines are drawn perpendicular to the mean orientation of each joint set to measure joint spacing. (a) Scan lines trend NNE-SSW, (b) scan lines trend NE-SW, (c) scan lines trend NW-SE, and (d) scan lines trend WNW-ESE. 
Table 3.2 Joint spacing statistics for the four joint sets obtained from scan line spacing measurements.

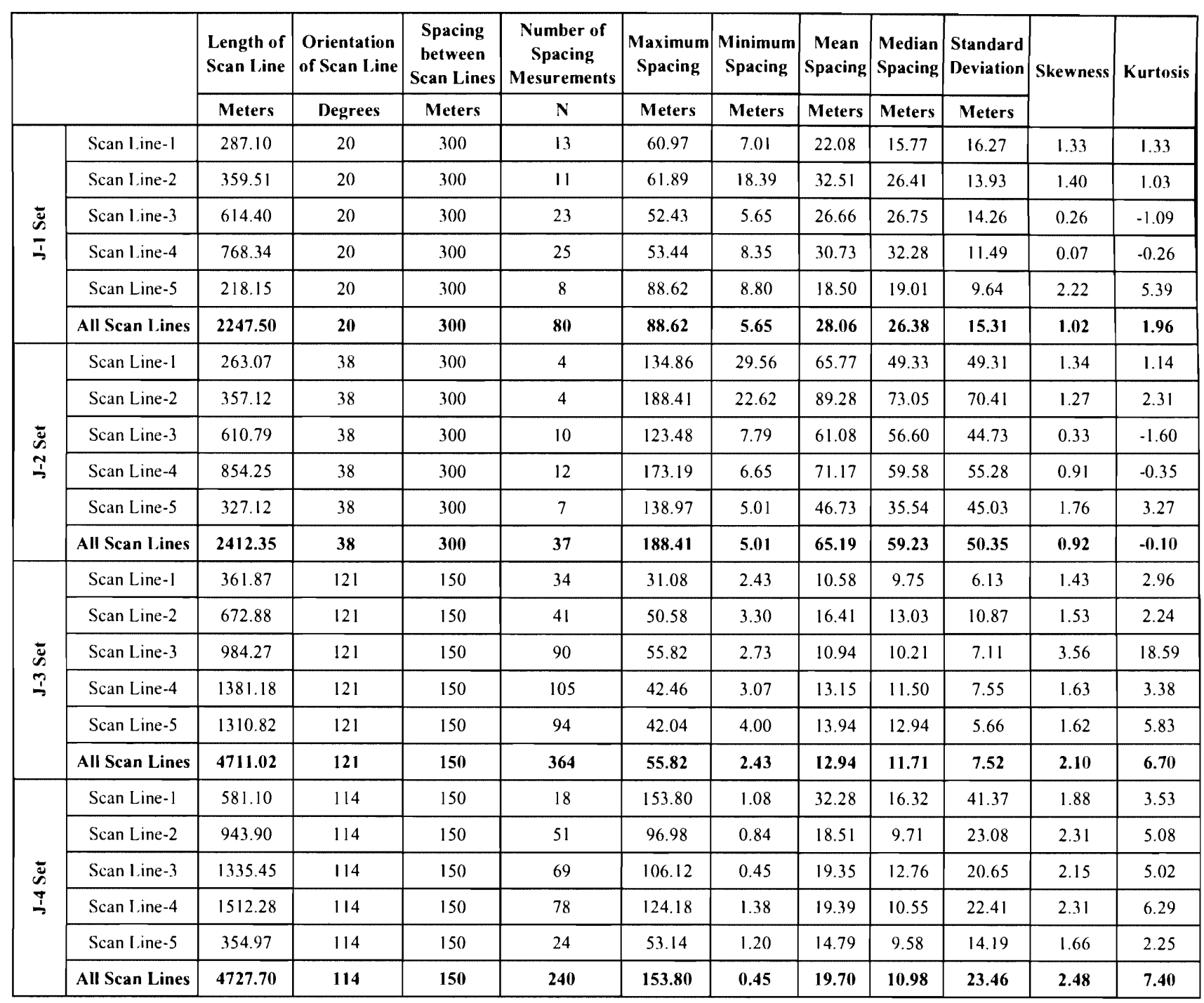


(a) Frequency Distribution of J-1 Spacing

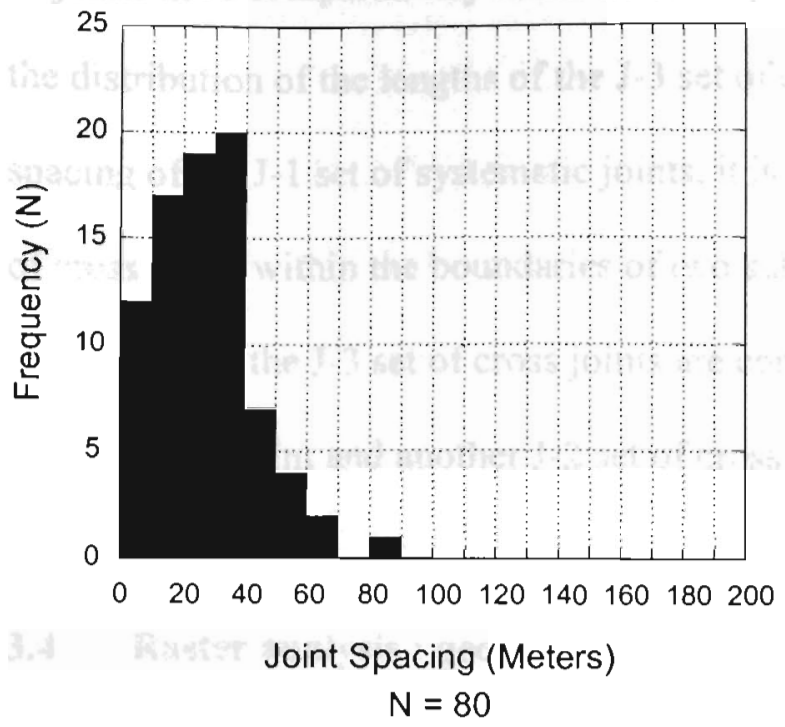

(c) Frequency Distribution of J-3 Spacing

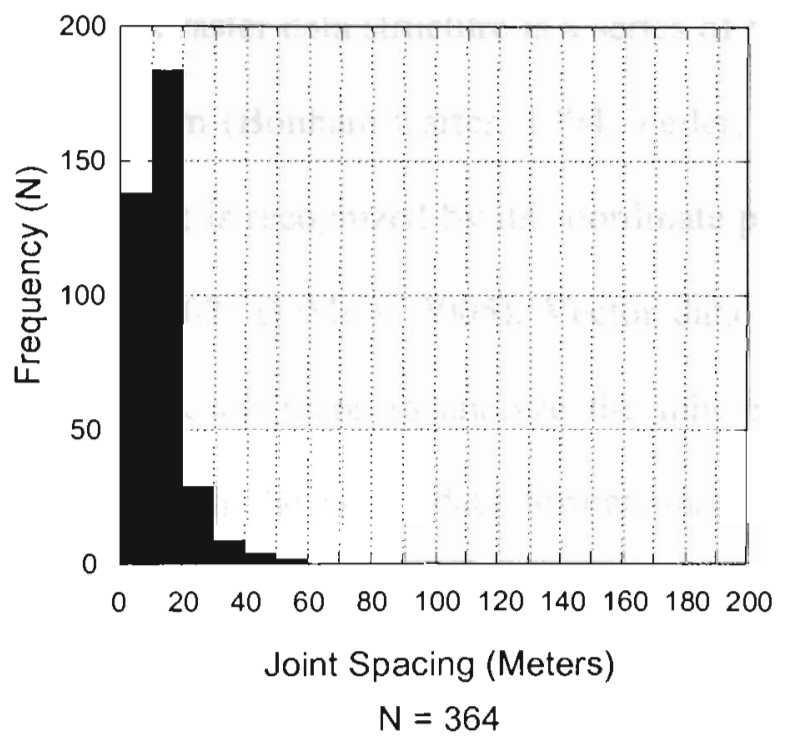

(b) Frequency Distribution of J-2 Spacing

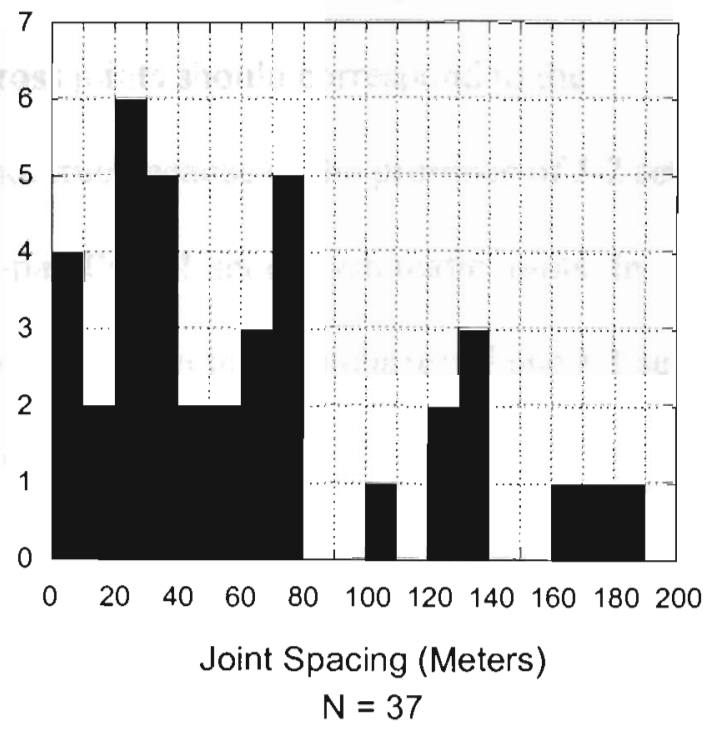

(d) Frequency Distribution of J-4 Spacing

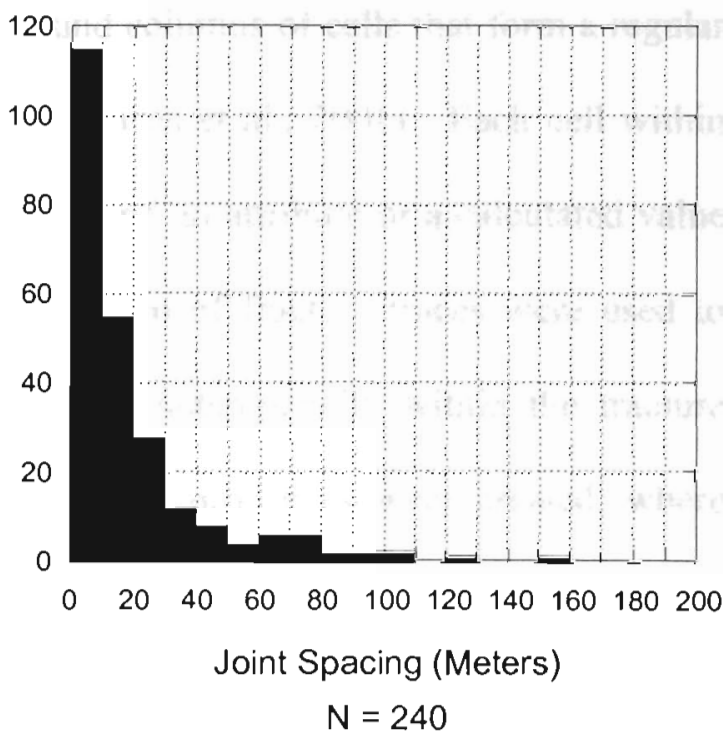

Figure 3.11 Histograms showing frequency distribution of joint spacing measurements of (a) J-1 joint set, (b) J-2 joint set, (c) J-3 joint set, and (d) J-4 joint set. 
of joints have comparatively lesser median spacing (Table 3.2). Although it seems that the distribution of the lengths of the J-3 set of cross joints should correspond to the spacing of the J-1 set of systematic joints, it is not true because of the presence of J-2 set of cross joints within the boundaries of two sub-parallel J-1 set of systematic joints. In some regions, the J-3 set of cross joints are confined within the boundaries of one J-1 set of systematic joint and another J-2 set of cross joint.

\subsection{Raster analysis : geospatial modeling of the fracture network}

A raster data structure is a series of rows and columns of cells that form a regular grid pattern (Bonham-Carter, 1994; Zeiler, 1999; Cacas et al., 2001). Each cell within this matrix is recognized by its coordinate position and an attribute or a calculated value (ESRI, 2002; DeMers, 2005). Vector data in the form of fracture traces were used to generate raster maps to analyze the inherent spatial heterogeneity within the fracture network. In the raster data format, maps of fracture properties were created, where computed values of fracture attributes were allocated to each cell within the gridded map area. The raster analysis was carried out by generating a series of raster grids of fracture properties. Distance buffer, fracture intensity, and fracture intersections density maps are the raster maps generated for geospatial analysis. 


\subsubsection{Distance buffer maps}

Raster maps of distance between fractures were computed using the 'Distance' function of the 'Spatial Analyst' extension of the ArcMap software (Mitchell, 1999; Longley, 2001; ESRI, 2002; DeMers, 2005). The distance buffer grid is a continuous surface representing the proximity to the nearest target fracture. The cell intersected by a fracture is assigned a zero distance value. The Euclidean distance to the closest fracture is calculated between each of the output cells that do not contain a fracture (Fig. 3.12).

Distance buffer maps were generated for each fracture set and the fracture network as a whole (Figs. 3.13, 3.14). The statistics of proximity to nearest fracture is summarized in Table 3.3.

The distance buffer map of the $\mathrm{J}-2$ set of cross joints portrays maximum distance between fractures (Fig. 3.13b), whereas the distance buffer map of the J-3 set of cross joints displays proximity to fractures (Fig. 3.13c; Table 3.3). Hence, it can be inferred that the J-2 set of joints are widely spaced, and the J-3 set of joints are closely spaced. The individual distance buffer zones for the J-1 set of systematic joints and the J-2 set of joints show linear trends in the WNW-ESE and nearly NW-SE directions respectively (Figs. 3.13a,b).

\subsubsection{Fracture intensity maps}

There are a number of ways to quantify fracture density. As defined by Renshaw (1997), fracture density is the summation of the half-length squared for all the fractures 


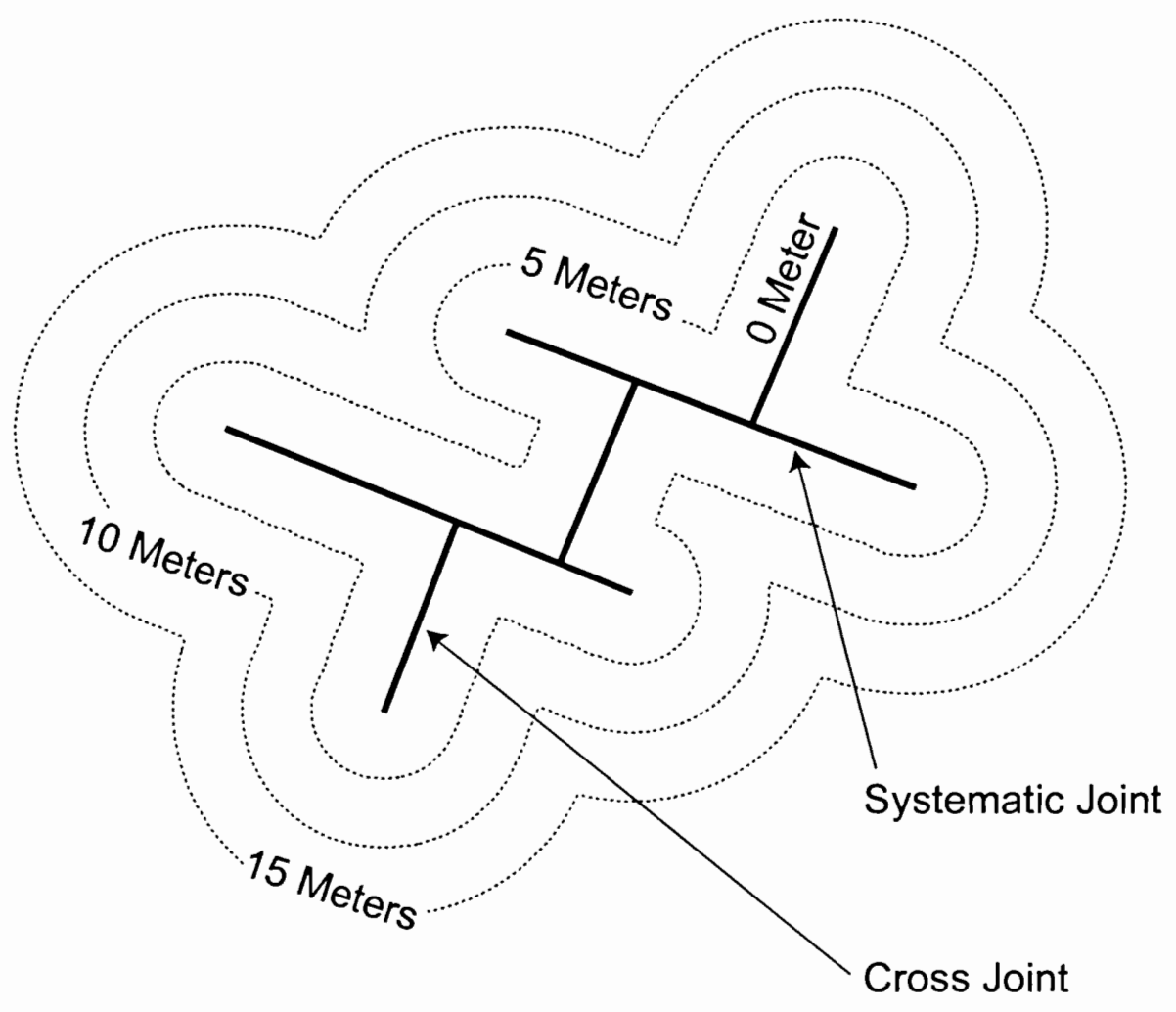

$5 \quad 0 \quad 5$ Meters

Figure 3.12 Schematic illustration showing procedure for the generation of distance buffer maps. Dotted lines are distance buffer contours. 


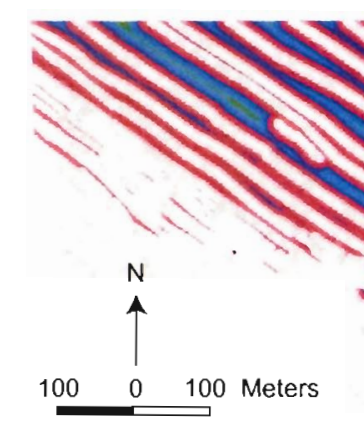

Distance Unit : Meters

(a)

$\begin{array}{ll}\square & 0-5 \\ 5-10 & 30-35 \\ 10-15 & 35-40 \\ 15-20 & 40-45 \\ 20-25 & 45-50 \\ 25-30 & 50-55 \\ 25 & 55-60\end{array}$

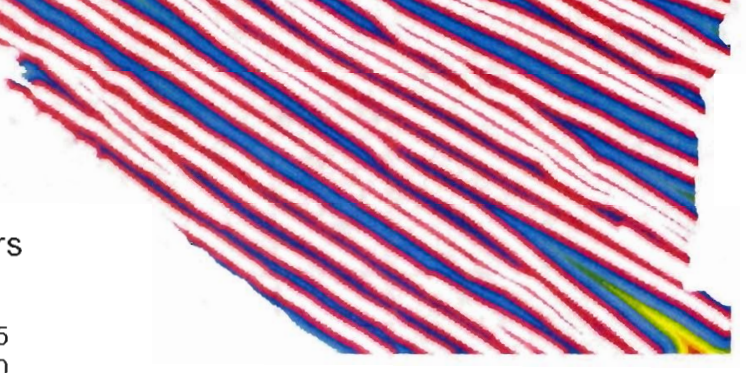

Projection : UTM, Zone-12, North Spheroid : GRS 1980 Datum : NAD 83

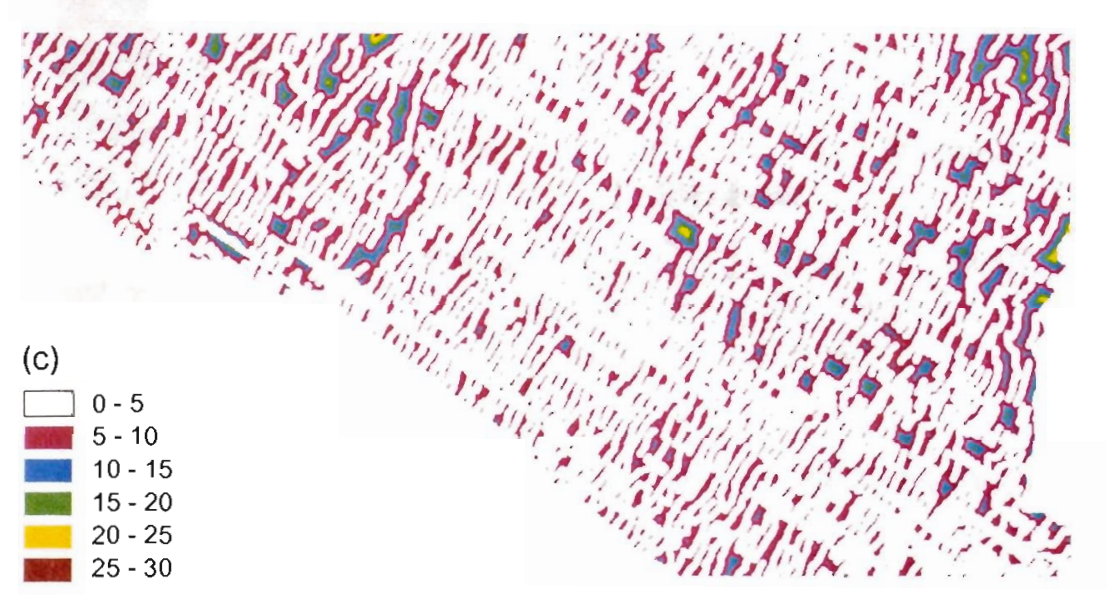

(b)

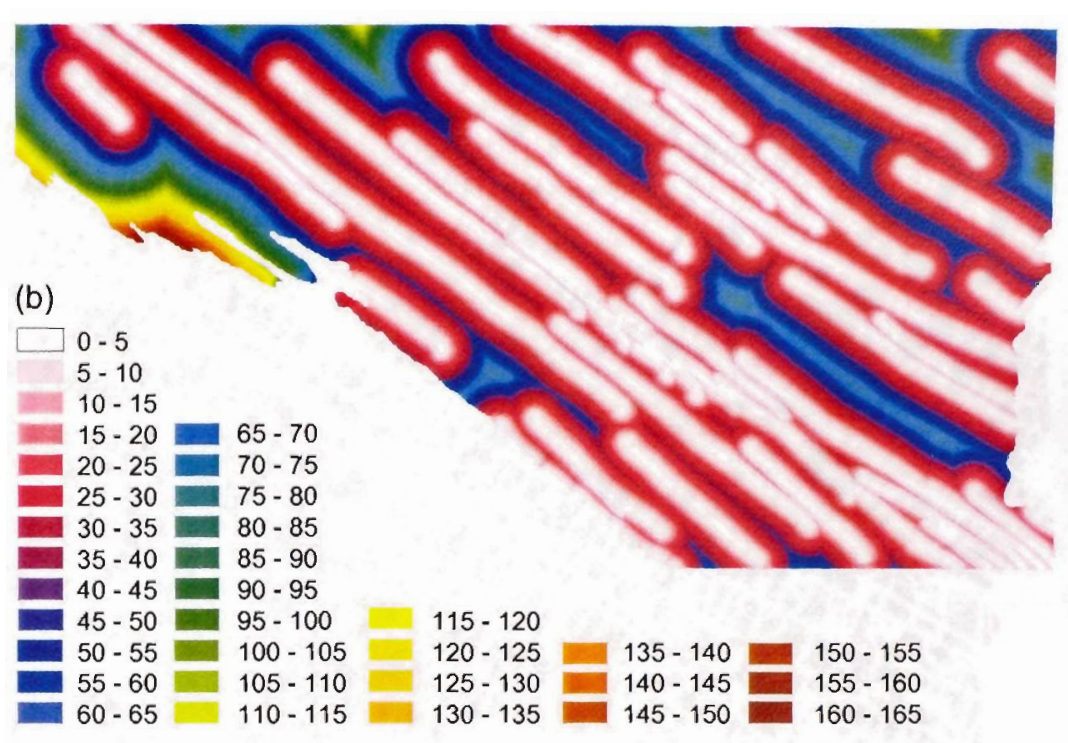

4r.

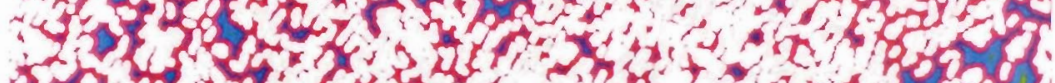

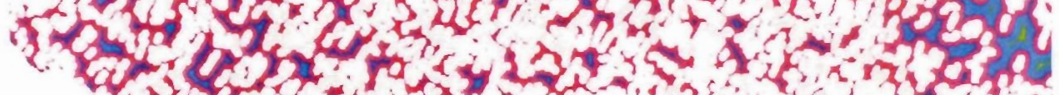
L. If

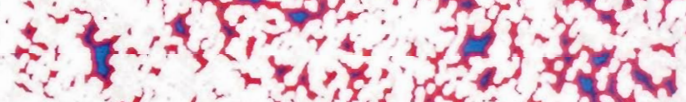

(d)

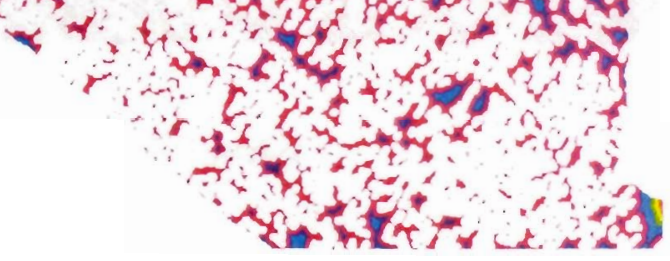

Figure 3.13 Maps showing distance between fractures for (a) J-1 joint set, (b) J-2 joint set, (c) J-3 joint set, and (d) J-4 joint set. Cell size in all of the above maps is 0.3 meter. 


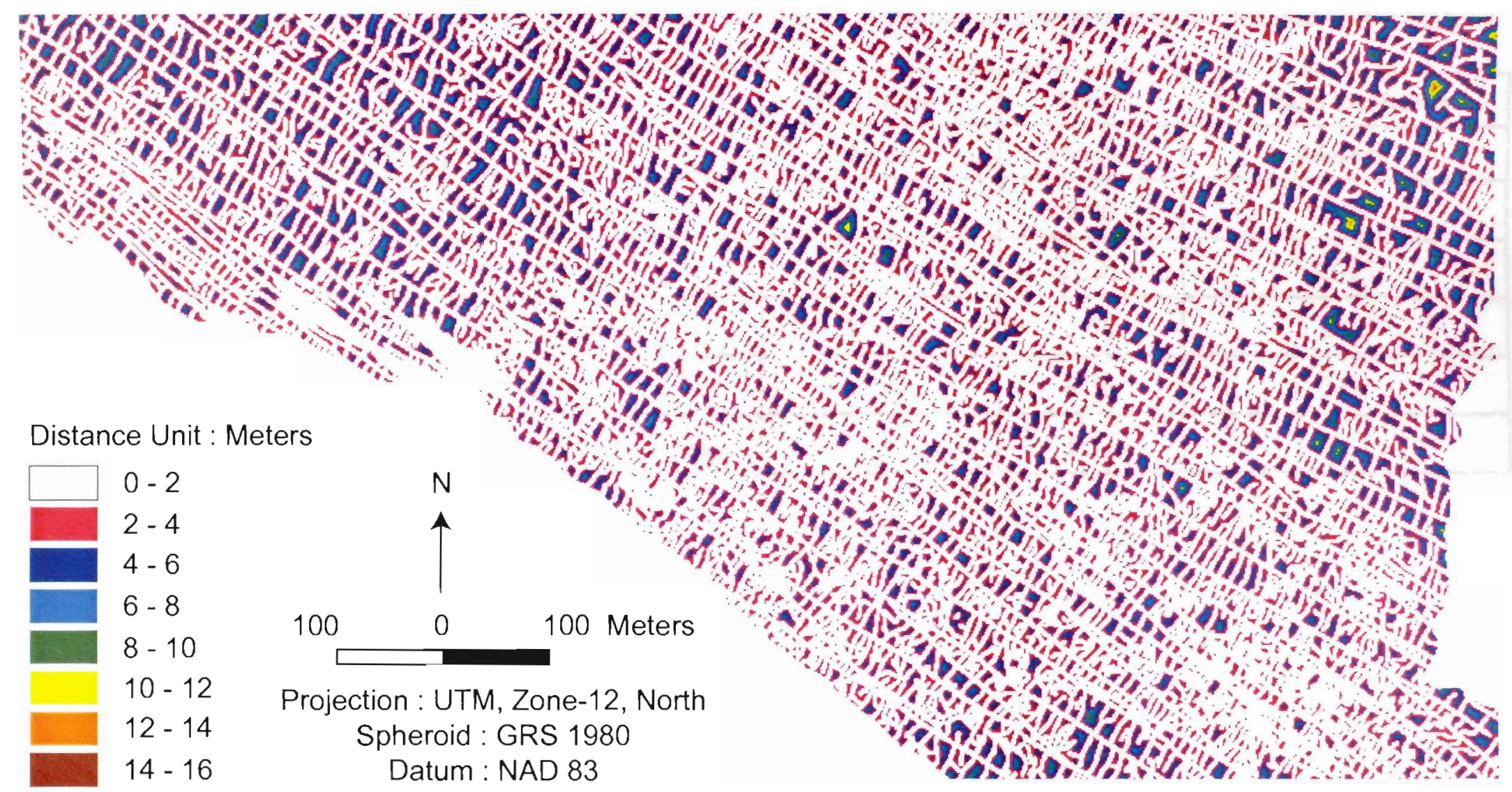

Figure 3.14 Map showing distance between fractures for the entire fracture network. Cell size is 0.3 meter. 
Table 3.3 Statistics of proximity to nearest fracture as obtained from the distance buffer analysis.

\begin{tabular}{|c|c|c|c|}
\hline & Maximum & Mean & Standard Deviation \\
\cline { 2 - 4 } & Meters & Meters & Meters \\
\hline J-1 Set & 57.86 & 9.00 & 6.98 \\
\hline J-2 Set & 164.47 & 27.51 & 25.15 \\
\hline J-3 Set & 28.32 & 3.58 & 2.93 \\
\hline J-4 Set & 41.45 & 4.36 & 3.69 \\
\hline The Fracture Network & 14.42 & 1.83 & 1.55 \\
\hline
\end{tabular}


divided by the area. Further, fracture density was also defined as the average number of fracture trace centers per unit area, and has a unit of $1 /$ length $^{2}$. The above two definitions of fracture density are different from each other. Fracture intensity is defined as the mean total trace length of the fractures per unit area (Dershowitz and Einstein, 1988; Mauldon et al., 2001), and has a unit of $1 /$ length. Fracture trace intensity characterizes both the fracture density and the fracture size, as it also incorporates fracture length (Dershowitz and Herda, 1992; Singhal and Gupta, 1999; Rohrbaugh et al., 2002).

For this study, a buffer zone of 25 meters towards the inside of the area of interest was excluded for fracture intensity analysis (Fig. 3.15). This compensates for any edge effects (Wu and Pollard, 1995), and is also applied for the analysis of the density of fracture intersections as described in the following section. In this case, fracture intensity is calculated using the 'Density' function of the 'Spatial Analyst' extension of the ArcMap software (ESRI, 2002). The function computes the fracture intensity by summing up all fracture trace lengths within a specified circular search area, and then dividing it by the search area (Finn, 2000). The unit of fracture intensity is 1/length (Fig. 3.16). The fracture intensity calculation is based on a nearest-neighbor analysis (Davis, 2002). The search radius $(r)$ for this study was selected through the following equation:

$$
r=(A / n)^{1 / 2},
$$

where $A$ is the entire area and $n$ is the number of fractures occupying the entire area (Ghosh, 2003). The fracture intensity grids were generated by using the kernel smoothing option of interpolation (ESRI, 2002) in order to produce a smooth density surface. Fracture intensity maps were produced for individual fracture sets and the fracture 


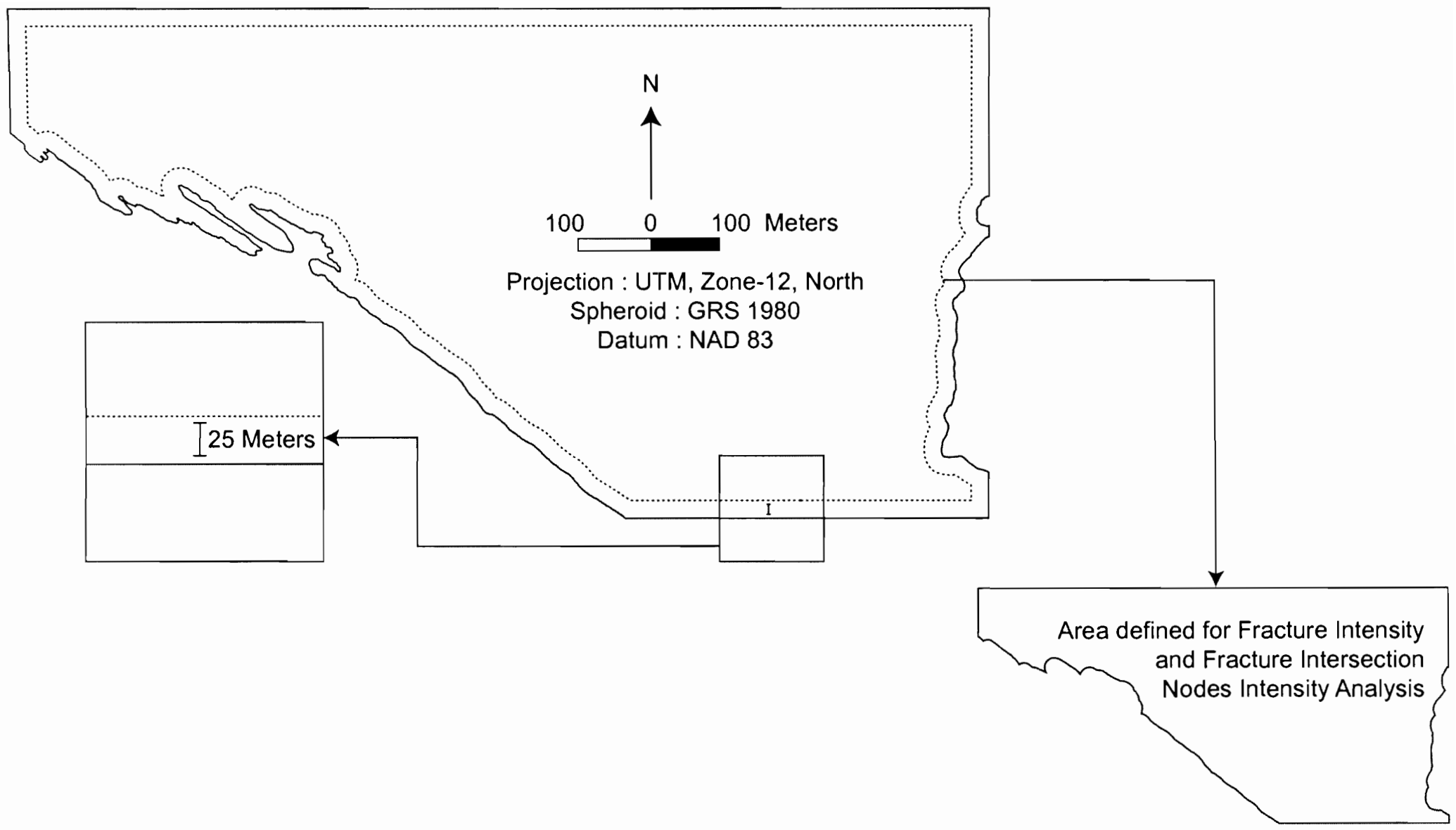

Figure 3.15 Analysis of fracture intensity and fracture intersections density were carried out after excluding an area comprising of a 25 meters buffer zone towards the inside of the area of interest. This is performed to compensate for edge effect. 


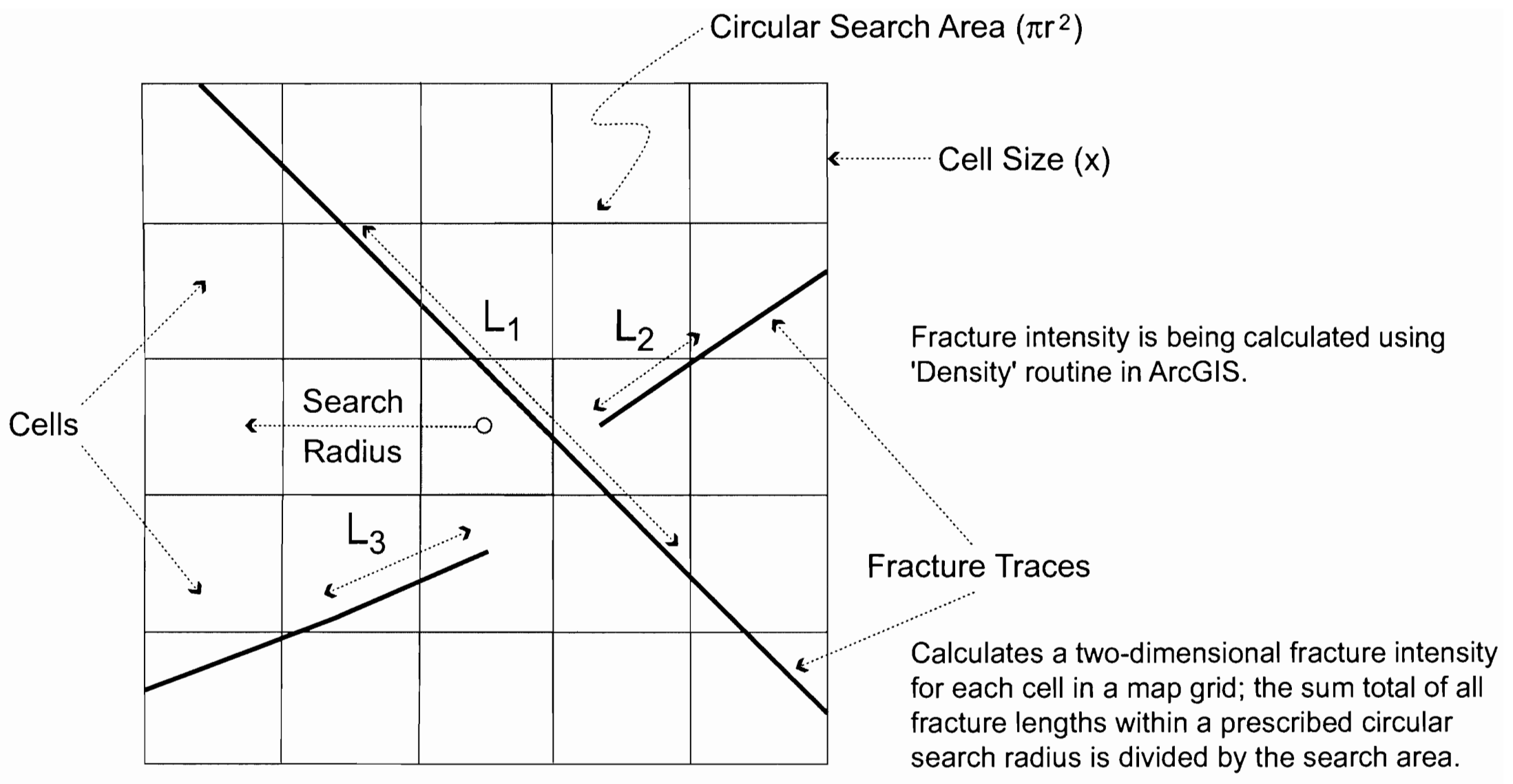

Two-dimensional Fracture Intensity $=\left(L_{1}+L_{2}+L_{3}\right) / \pi r^{2}$, where $r$ is the Search Radius.

Figure 3.16 Fracture intensity is described as the mean total trace length of fractures per unit area. Hence, the unit of fracture intensity is $1 /$ length (after M. Gross). 
network as a whole (Figs. 3.17, 3.18). The fracture intensity statistics are presented in Table 3.4, and the histograms in Figures 3.19 and 3.20.

Visual inspection of the fracture intensity maps for the J-1 set and the J-2 set of joints show linear trends of high fracture intensity values in the WNW-ESE and nearly NW-SE directions respectively (Figs. 3.17a,b). Further, the fracture intensity map of the entire fracture network displays occurrences of maximum fracture intensity (Table 3.4), and also linear trends of high fracture intensity values in the WNW-ESE to NW-SE directions (Fig. 3.18). The frequency histograms of all the fracture intensity maps show positively skewed distributions of fracture intensity values (Figs. 3.19, 3.20).

\subsubsection{Density map of the fracture intersections}

Nodes of fracture intersections and terminations (Fig. 3.21) are important for the spatial analysis of fractures, because nodes trap soil and nutrients that sustain desert vegetation. Fracture intersections facilitate transmission of fluids through the fracture network. A density analysis of fracture intersections was performed using the same techniques applied for fracture intensity analysis in section 3.4.2. The fracture intersections were identified and separated using the 'Edit Tools' extension of the ArcView GIS software (Fig. 3.22). Then, the density of fracture intersections was calculated using the 'Density' function of the 'Spatial Analyst' extension within the ArcMap software (ESRI, 2002). The function computes the density of fracture intersections by counting the total number of fracture intersections within a specified circular search area, and then dividing it by the search area (Longley, 2001; Lo and 


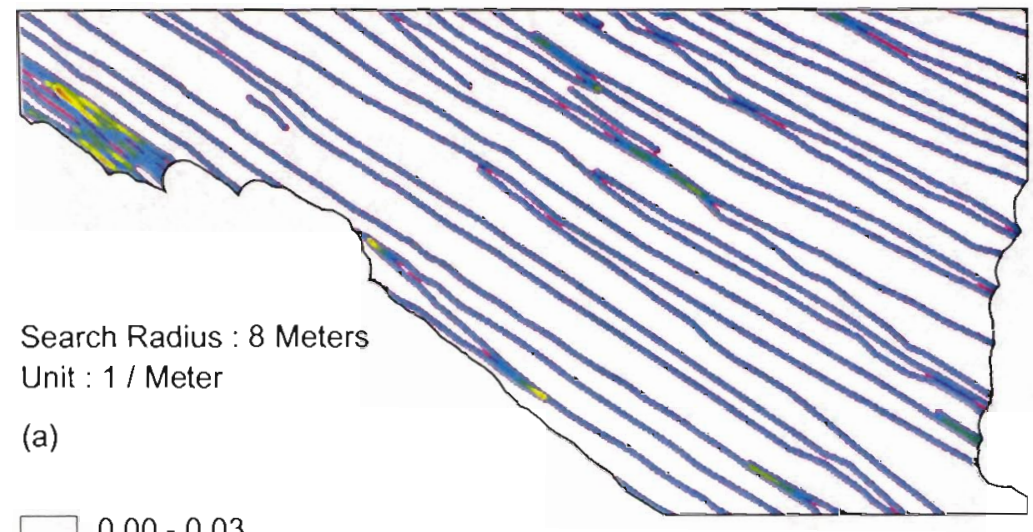

$0.00-0.03$

$0.03-0.06=0.15-0.18$

$0.06-0.09 \quad 0.18-0.21$

$0.09-0.12=0.21-0.24$

$0.12-0.15$

$0.24-0.27$

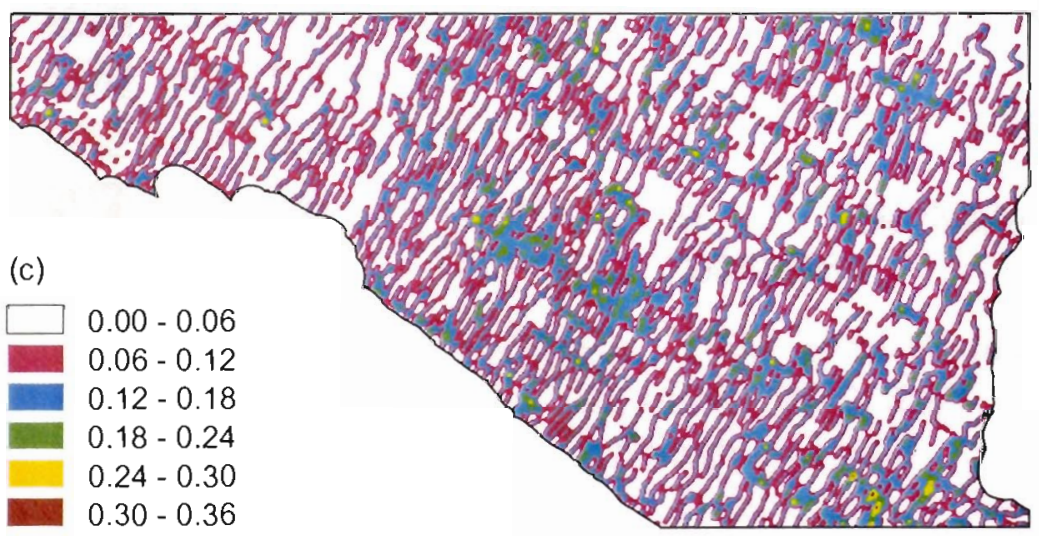

Projection : UTM, Zone-12, North Spheroid: GRS 1980

Datum : NAD 83

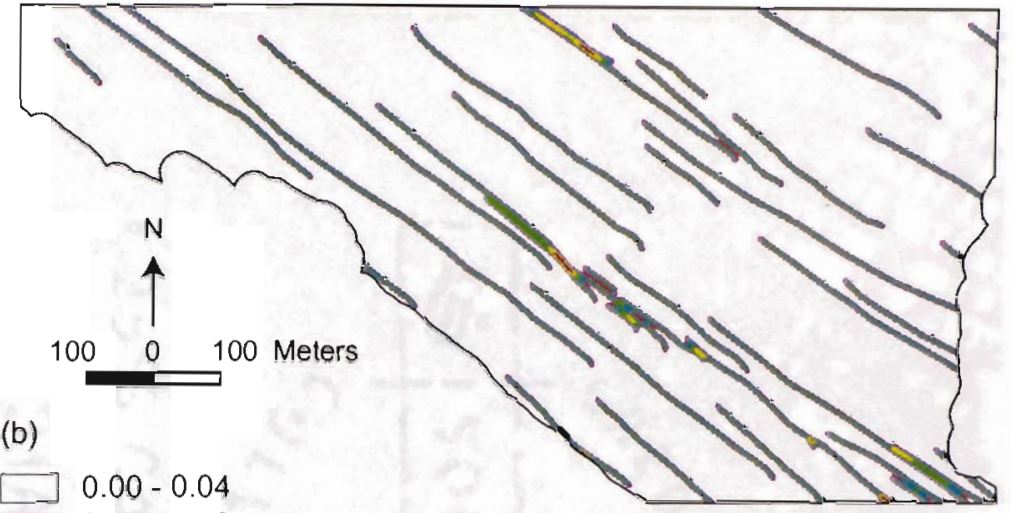

$0.04-0.08$

$0.09-0.12$

$0.12-0.16$

$0.16-0.20$

$0.21-0.24$

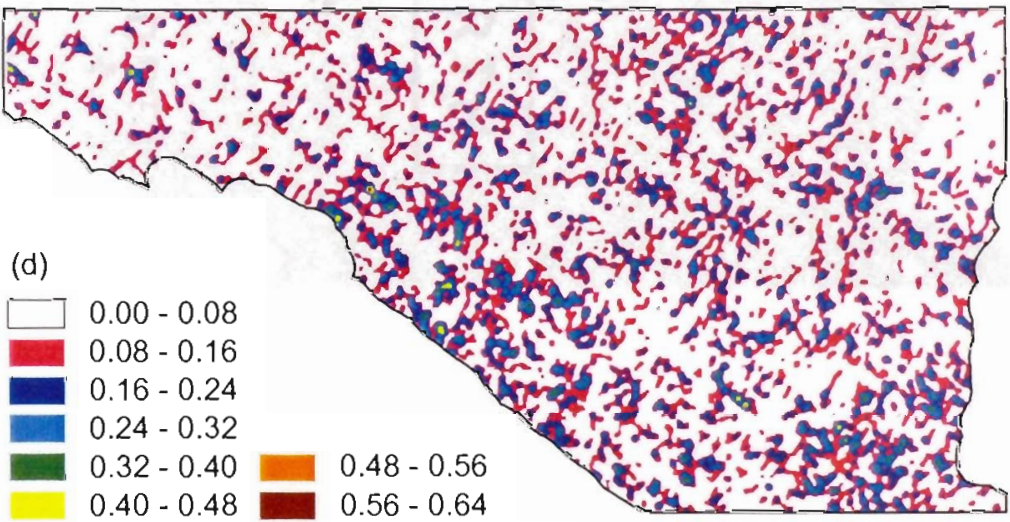

Figure 3.17 Fracture intensity maps of (a) J-1 joint set, (b) J-2 joint set, (c) J-3 joint set, and (d) J-4 joint set. Cell size in all of the above maps is 0.3 meter and the search radius is 8 meters. 


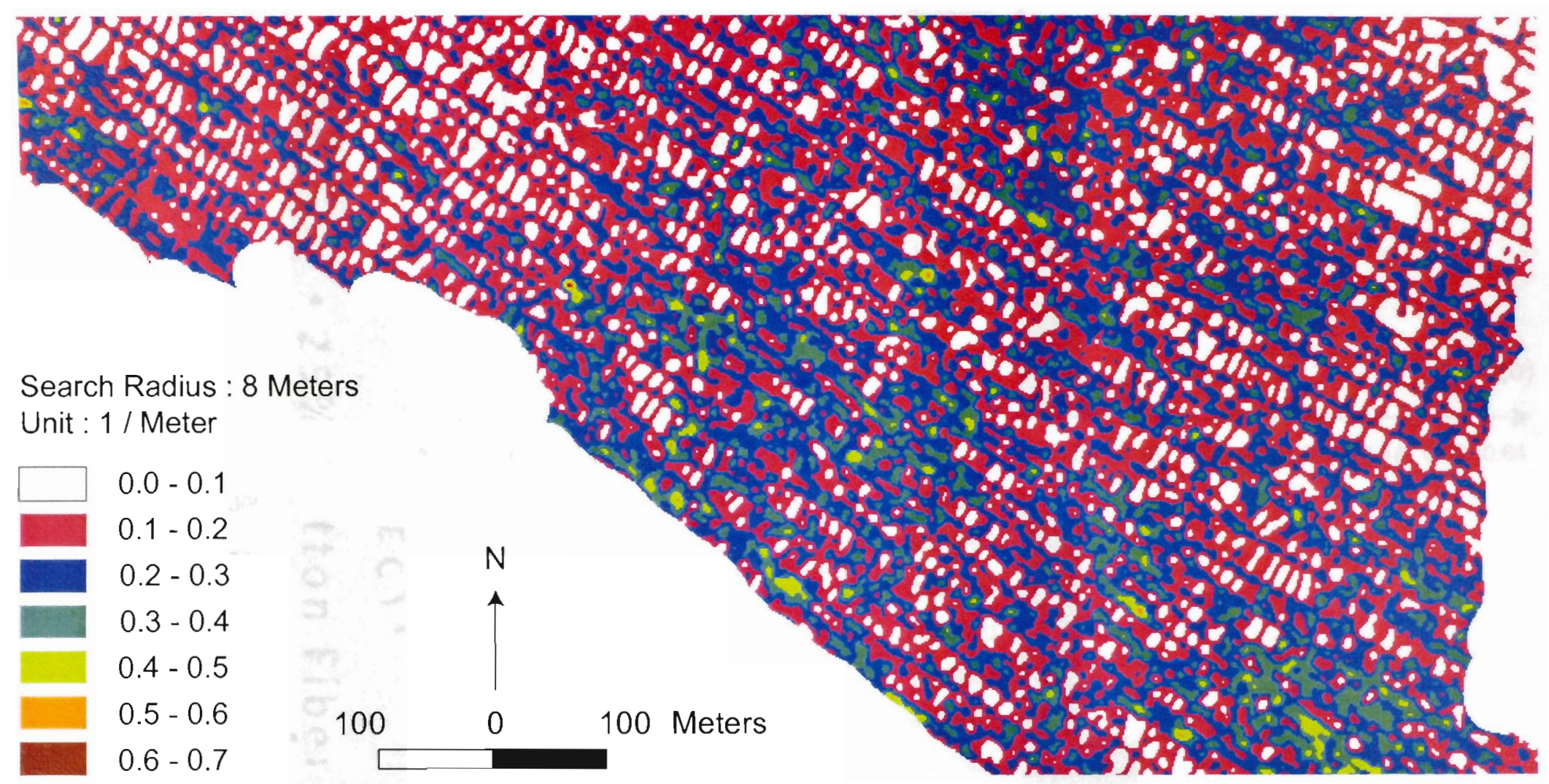

Projection : UTM, Zone-12, North

Spheroid : GRS 1980

Datum : NAD 83

Figure 3.18 The intensity map of the entire fracture network. Cell size is 0.3 meter and the search radius is 8 meters. 

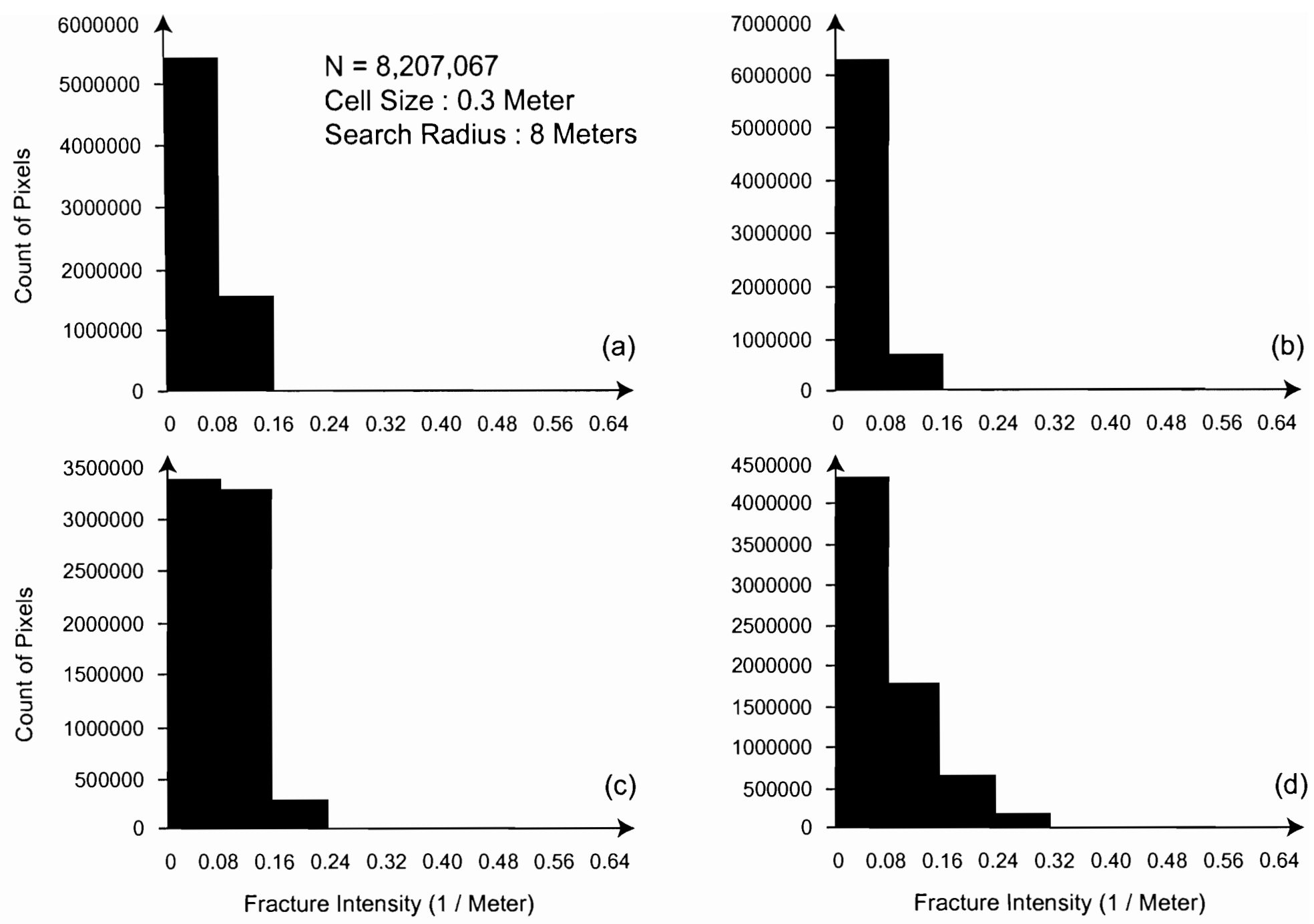

Figure 3.19 Histograms of fracture intensities for (a) J-1 joint set, (b) J-2 joint set, (c) J-3 joint set, and (d) J-4 joint set. 
Table 3.4 Fracture intensity statistics as obtained from fracture intensity maps.

\begin{tabular}{|c|c|c|c|}
\hline & Maximum & Mean & Standard Deviation \\
\cline { 2 - 4 } & 1/Meter & 1/Meter & 1 / Meter \\
\hline J-1 Set & 0.26 & 0.03 & 0.05 \\
\hline J-2 Set & 0.24 & 0.02 & 0.04 \\
\hline J-3 Set & 0.33 & 0.08 & 0.05 \\
\hline J-4 Set & 0.60 & 0.07 & 0.07 \\
\hline The Fracture Network & 0.64 & 0.18 & 0.08 \\
\hline
\end{tabular}

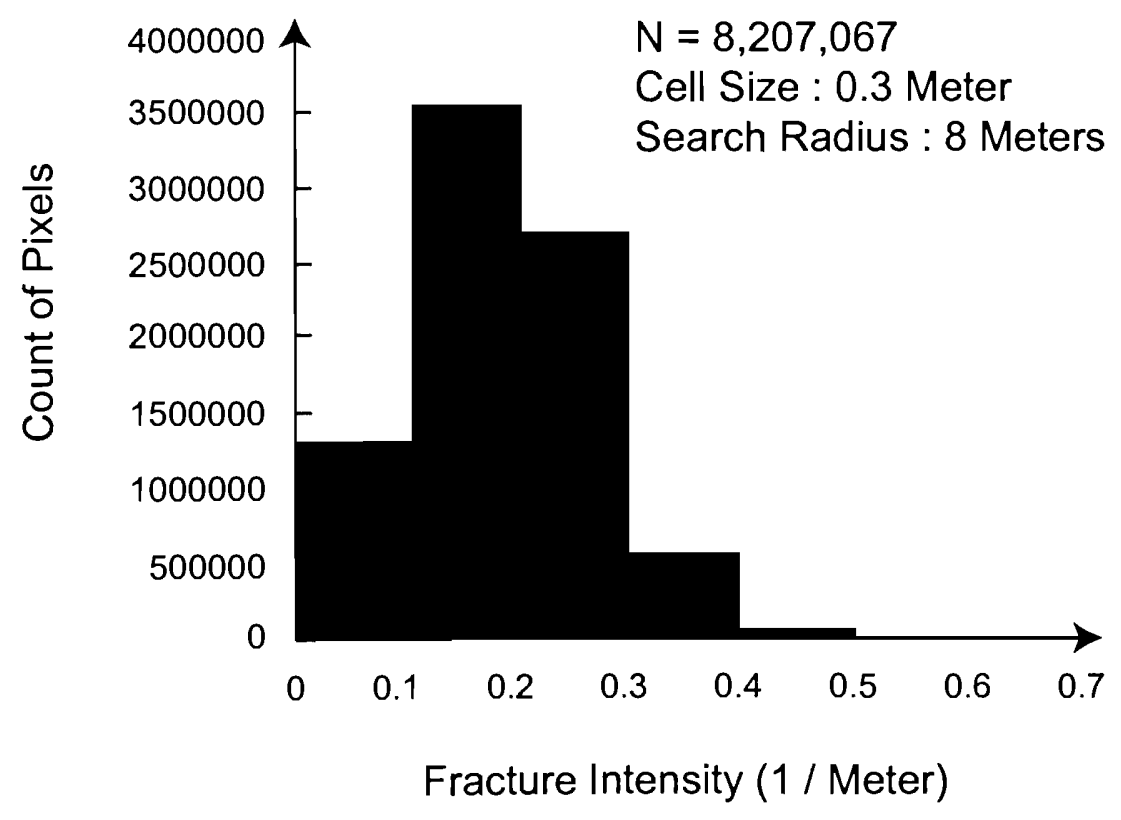

Figure 3.20 Frequency distribution of fracture intensity of the entire fracture network. 


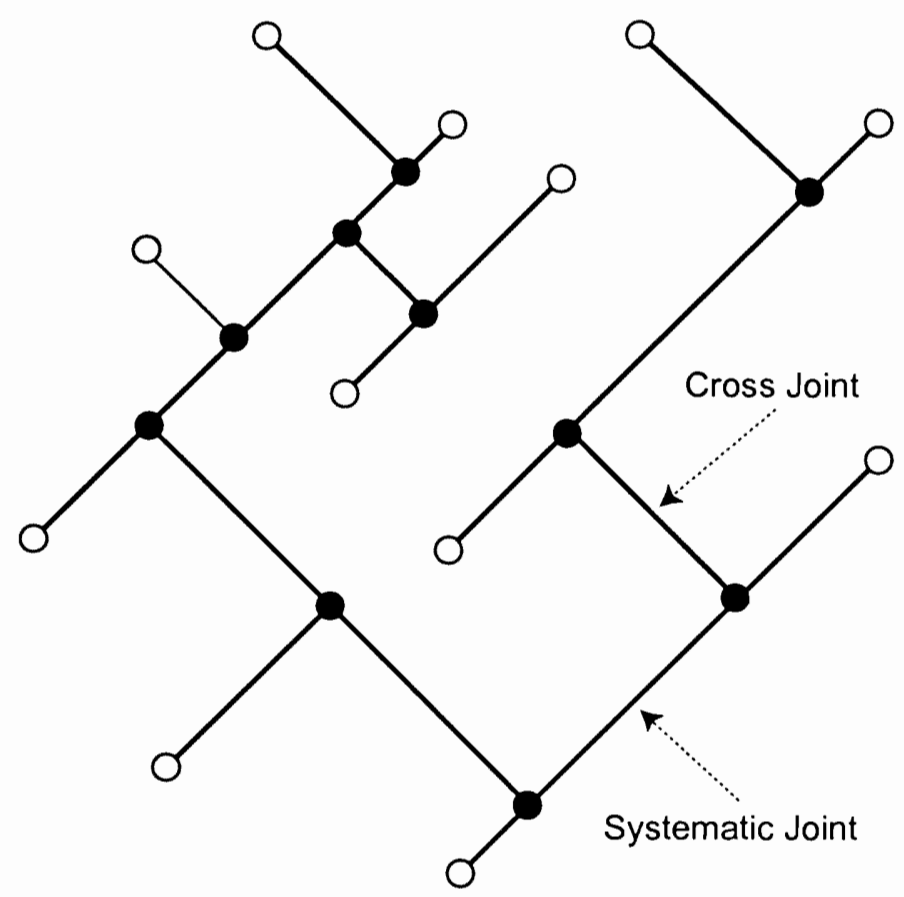

- Fracture Intersection Node

Fracture Termination Node

Figure 3.21 Schematic illustration showing nodes of fracture intersections and fracture terminations. 


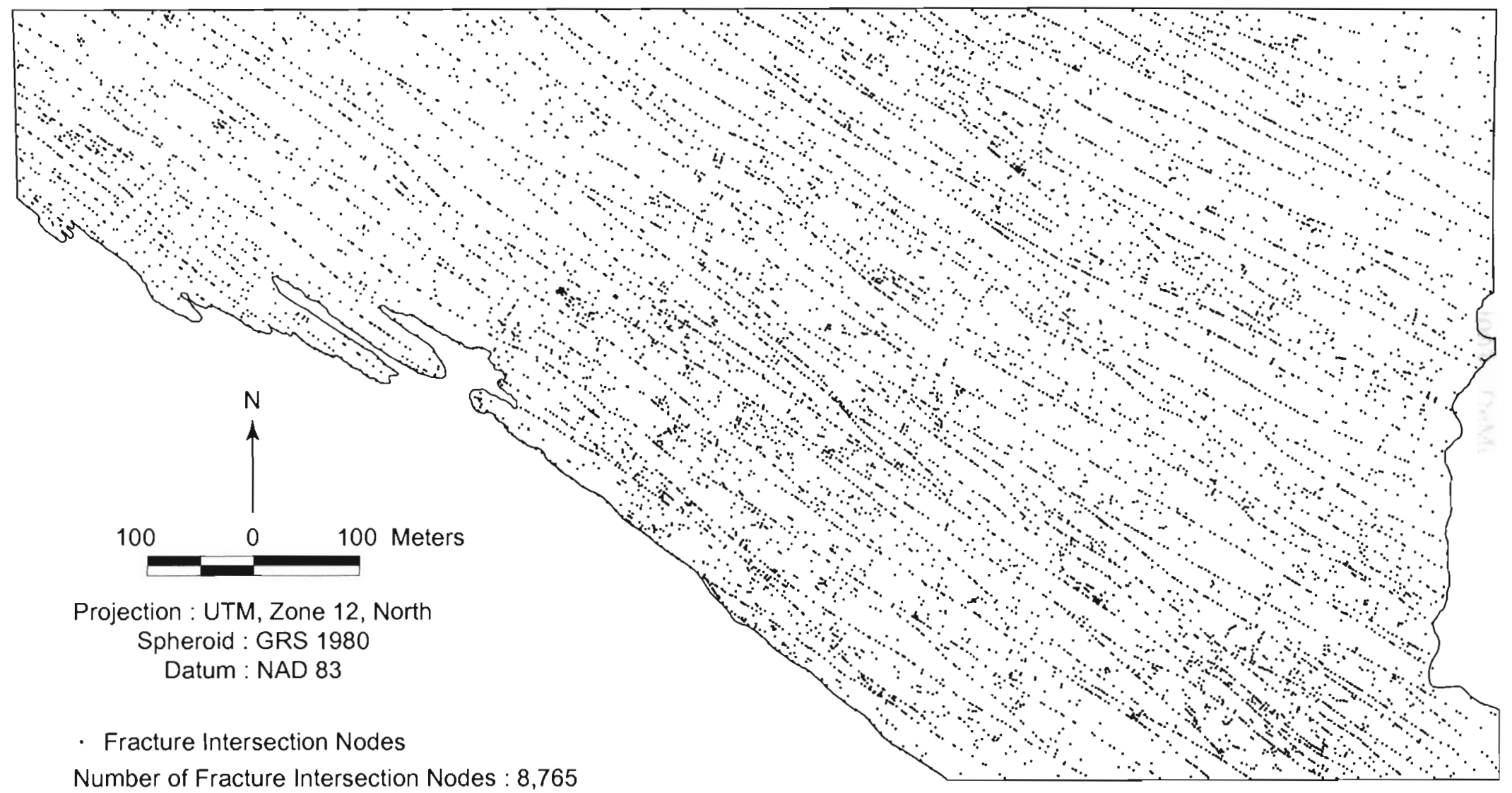

Figure 3.22 Spatial distribution of fracture intersection nodes within the fracture network. 
Yeung, 2002; Gupta, 2003; DeMers, 2005). The unit of the density of fracture intersections is $1 /$ length ${ }^{2}$.

The search radius for generating the fracture intersections density map was determined by the same criteria as applied for fracture intensity analysis; in this case, $n$ is the number of fracture intersections occupying the area. The density grid was generated by using the kernel smoothing option of interpolation (ESRI, 2002). The intersection density map (Fig. 3.23) was studied, and the statistics were plotted in a histogram (Fig. $3.24)$.

The spatial distribution of fracture intersections shows linear trends in the WNWESE and nearly NW-SE directions (Fig. 3.22). The search radius for intersection density analysis was 9 meters. This specific numerical value for the search radius was obtained by calculating the square root of the ratio between the area of interest and total number of fracture intersections within the fracture network. Visual inspection of the density map reveals linear trends of high density values in the WNW-ESE to NW-SE directions (Fig. 3.23). The frequency histogram generated from the density map shows positively skewed distribution of intersection density values (Fig. 3.24).

\subsection{Discussion}

During the digitization of fracture traces over the color aerial photograph (Fig. 2.9), at places fracture traces had to be drawn over the vegetation while tracking the continuity of the mega-scale fractures. Further, it was observed in the field that vegetation is growing within the fractures, and is not continuous throughout the extent of 


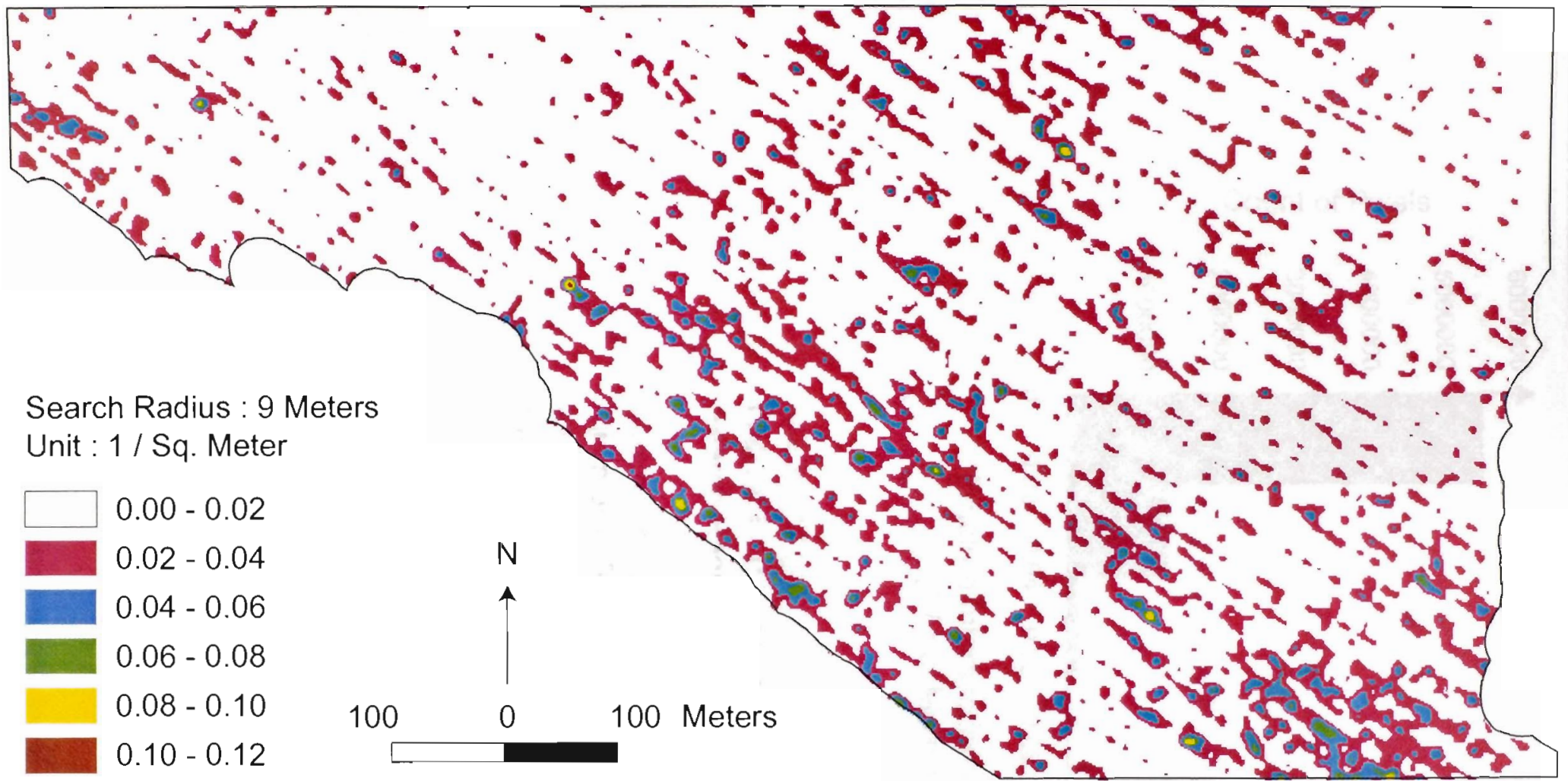

Projection : UTM, Zone-12, North

Spheroid : GRS 1980

Datum : NAD 83

Figure 3.23 Density map of the fracture intersections. Note distinct NW-SE trend. Cell size is 0.3 meter and the search radius is 9 meters. 


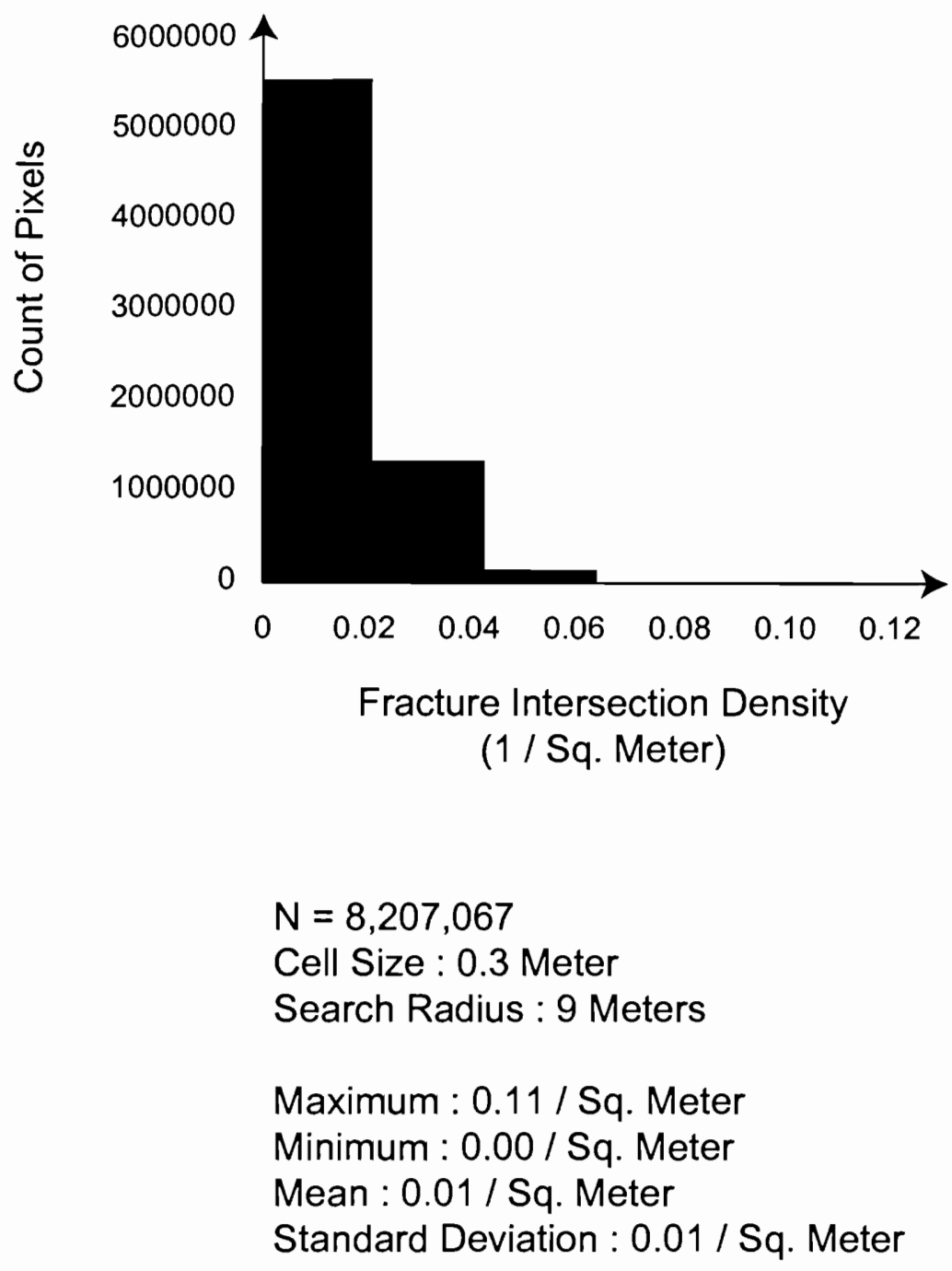

Figure 3.24 Frequency distribution of fracture intersection density of the entire fracture network. 
the fractures. Hence, the vegetation is partly obscuring the traces of the fractures (Figs. 2.7, 3.25). This justifies connecting the vegetation-filled gaps between exposed segments of fractures to be digitized and considered as masked traces of a single and continuous large-scale fracture (Fig. 3.2a,b).

The digitized trace map of the fracture network reveals that the J-2 set of joints are contained within the boundaries of the J-1 set of systematic joints and also abut against the J-1 set of systematic joints, either curving parallel or curving perpendicular to the J-1 set of joints (Figs. 2.7c, 3.1b). Hence, the J-2 set of joints are cross joints, and can be separated from the J-1 set of systematic joints. In other words, the J-2 set of joints are confined within the extents of two sub-parallel J-1 set of joints. This explains that the J-2 set of joints developed after the formation of the J-1 set of joints. Similarly, the J-3 set of cross joints are contained within the extents of the J-1 set of systematic joints (Fig. 2.7b), and the J-2 set of cross joints. Hence, it can be deciphered that the J-3 set of joints developed after the formation of J-1 set and J-2 set of joints. The J-4 set of nonsystematic polygonal joints (Fig. 3.1d) are limited by the extent of the J-3 set of joints. Therefore, it can be concluded that the J-4 set of joints are the most recent. In chronological order of development, the J-1 set of joints are the oldest, then the J-2 set and the J-3 set of joints developed respectively, and finally during a later phase the J-4 set of joints developed. Nonetheless, the polygonal shape of the J-4 set of joints explains that this particular set was not the result of any tectonic deformation, but possibly an outcome of near-surface unloading. The fracture network is well connected (Fig. 3.3). The J-1 set of joints span from one side of the fracture network to the other side (Fig. 3.2a), and 
Systematic Joint trending NW-SE, partly concealed by Vegetation

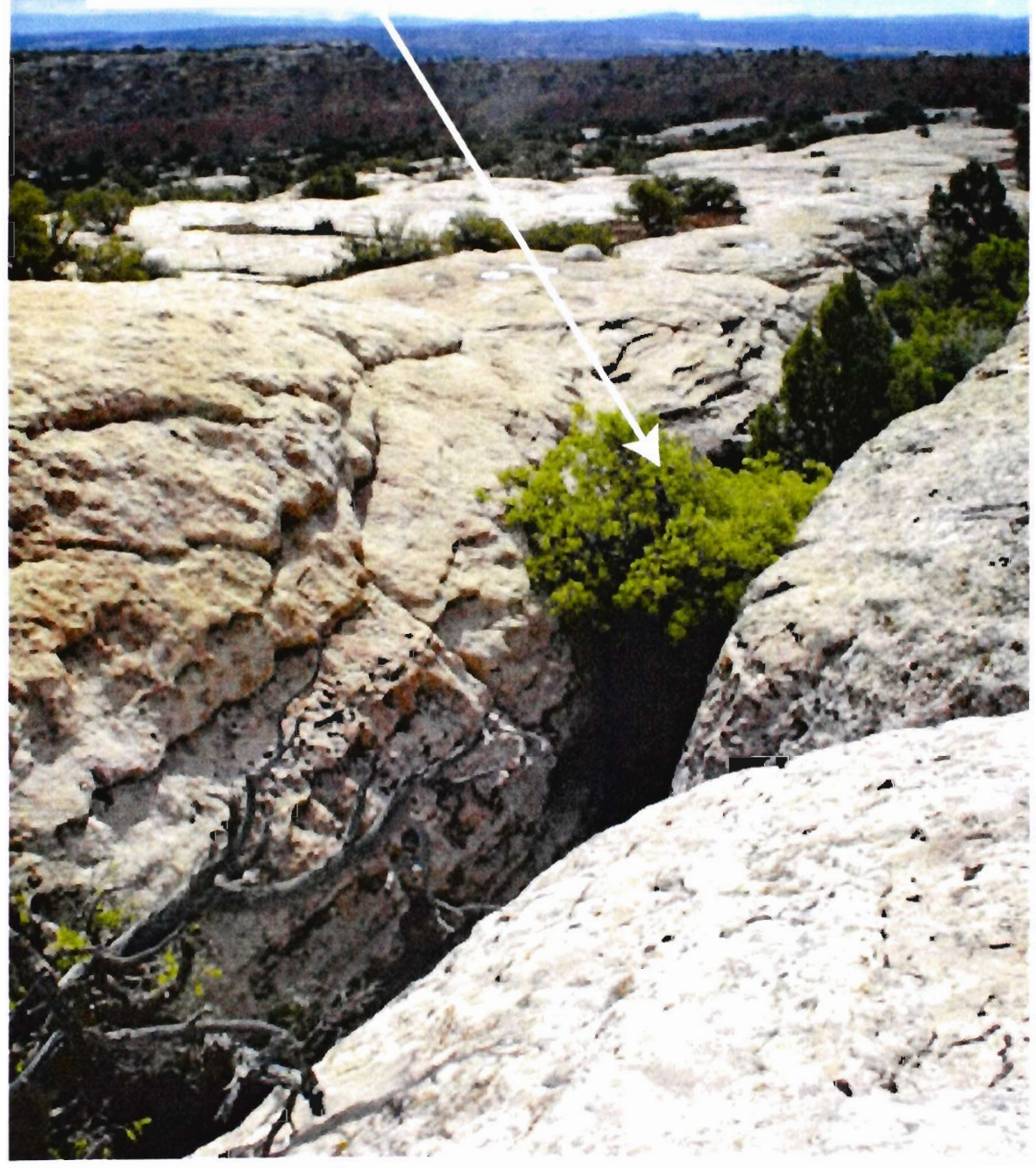

Figure 3.25 Field photograph of a systematic joint (J-1). Note that vegetation is growing within the aperture of the joint, and thus partly obscuring the trace of the joint. 
hence, the network has a backbone defined simply by the J-1 set of joints only, irrespective of the other sets of joints.

The purpose of characterizing the fracture network was to analyze and understand the spatial heterogeneity within the fracture network using GIS spatial analyses. This was achieved by a series of vector and raster analyses as described in the previous sections.

Results obtained from the analysis of fracture network properties would be subsequently used to compare with the vegetation occurrences in order to establish a spatial correlation between fracture network properties and the distribution of surface vegetation. 


\section{Chapter 4}

\section{LANDCOVER CLASSIFICATION}

\subsection{Overview}

An automated digital landcover classification of the study area was carried out on the basis of spectral pattern recognition. The purpose of the image classification procedure was to categorize all pixels of the rectified color aerial photograph of the study area (Fig. 2.9) into different spectral patterns, also known as landcover classes or themes. Multispectral data derived from the true-color aerial photograph were used to perform the image classification of a predefined area of interest within the study area (Fig. 2.10). The spectral pattern of each pixel (i.e., the set of radiance measurements obtained in the red, blue and green wavelength bands) was used as the numerical basis for the classification. Different spectral patterns were represented by different combinations of digital numbers based on their natural spectral reflectance and emittance properties (Fig. 4.1). Using ERDAS Imagine software, I classified the area of interest into three thematic landcover patterns or classes - bedrock, sand and vegetation. This was accomplished using an unsupervised classification technique, as explained in detail in the following paragraphs.

\subsection{Unsupervised classification technique}

The unsupervised image classification technique is a useful method for segregating digital remote sensing data in multispectral feature space to obtain landcover 
information (Loveland et al., 1999; Huang, 2002). This is a process whereby numerical operations are performed to identify natural groupings of pixels or patterns in a digital image based on their spectral signatures. This clustering process results in a classification map consisting of discrete spectral classes, but does not utilize a priori training data as the basis for the classification. The basic principle of unsupervised classification is that values within a landcover type should be close together in multispectral feature space (i.e., share similar spectral signatures), whereas data in different classes should be comparatively well separated.

In the unsupervised classification approach, the identities of landcover types to be specified as classes within a scene are initially unknown. The software groups the pixels with similar spectral characteristics into unique clusters according to some statistically determined criteria (Duda et al., 2001), and then separates the pixels into spectral clusters with no direction from the analyst (Sabins, 1997). The technique requires minimal input from the analyst. The analyst assigns or transforms the spectral clusters by relabeling and combining them into thematic information classes (Jensen, 2005). The image data are first classified by aggregating them into the natural spectral groupings or clusters present in the scene, and then the analyst determines the landcover identity of these spectral groups by comparing the classified image to ground reference data (Lillesand et al., 2004). So far, hundreds of clustering algorithms have been developed (Schowengerdt, 1997; Duda et al., 2001).

Using the unsupervised classification technique, I identified the spectrally distinct, separable clusters in the color aerial photograph. Results from the initial analysis were further evaluated by sorting and merging the spectral clusters. The final landcover 
classification was performed using the maximum likelihood classifier (Lillesand et al., 2004) as explained in the following sections.

\subsection{ISODATA clustering algorith $m$}

I applied the Iterative Self-Organizing Data Analysis Technique (ISODATA), a widely used clustering algorithm that incorporates a broad range of statistical procedures into an iterative classification procedure (Tou and Gonzalez, 1974; ERDAS, 2002; Stow et al., 2003; Rees et al., 2003). The ISODATA algorithm, a variant of the K-means clustering algorithm (Lillesand et al., 2004), requires the analyst to specify the maximum number of spectral clusters to be identified (i.e. the number of classes to be generated), the maximum number of times ISODATA is to classify pixels and recalculate cluster mean vectors (i.e. the number of iterations to be performed), and the maximum percentage of pixels whose class values are allowed to remain unchanged between the iterations (also known as the convergence threshold). The algorithm permits the number of clusters to change from one iteration to the next by merging, splitting, and deleting clusters (Lillesand et al., 2004). The ISODATA method uses the minimum spectral distance to assign a cluster for each candidate pixel. The process begins with a specified number of arbitrary cluster means or the means of existing signatures (Fig. 4.2), and then it processes repetitively so that those means shift to the means of the clusters in the data (ERDAS, 2002). In order to classify the landcover for the area of interest, I applied the ISODATA algorithm with twenty initial spectral classes, twenty iterations and a 0.99 convergence threshold. The numbers of initial spectral clusters, the numbers of iterations, 


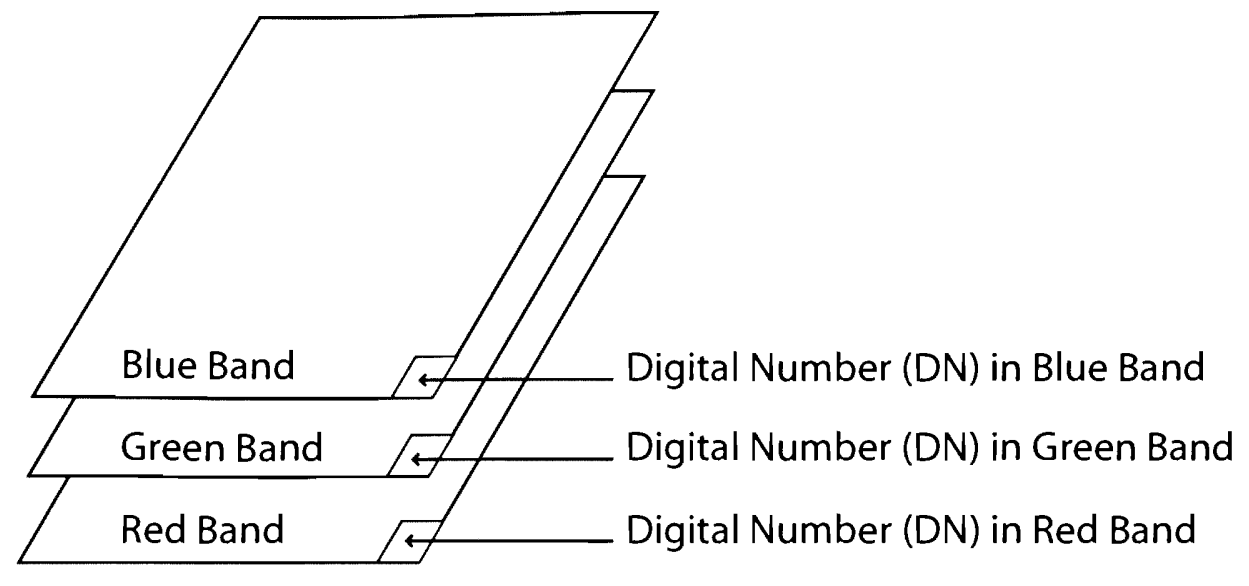

One Pixel

Figure 4.1 Three layers showing three bands of a multispectral image. Each pixel has three different digital numbers (DNs) in three bands (after ERDAS, 2002).

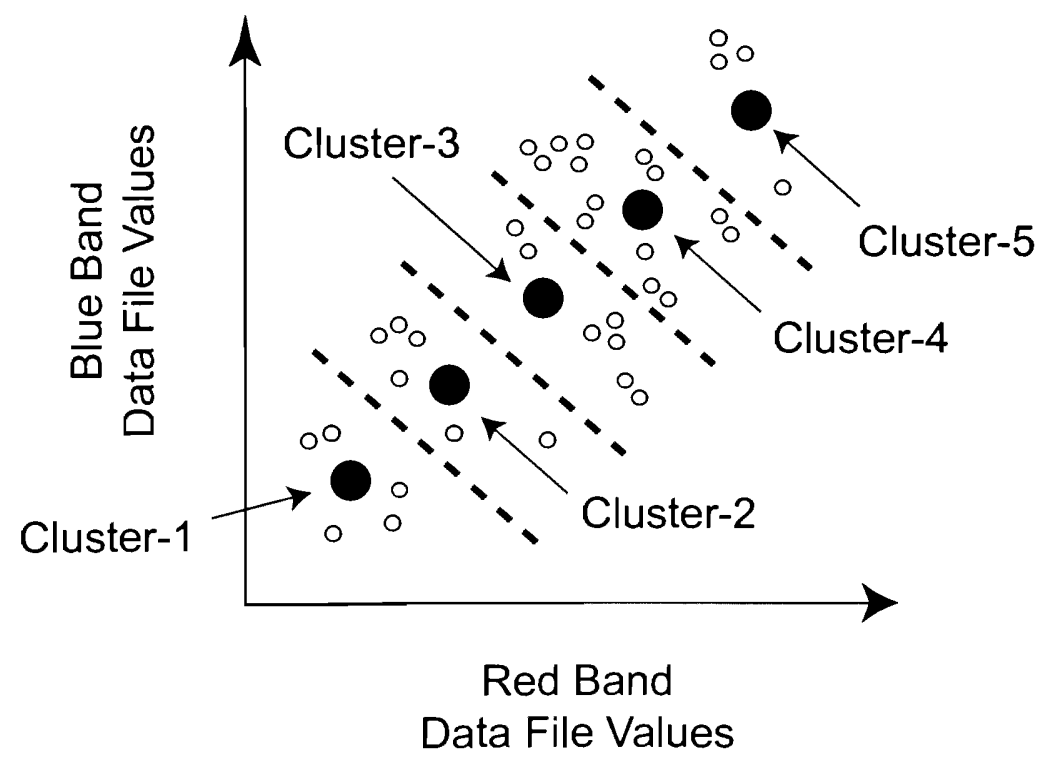

Figure 4.2 Schematic diagram of the ISODATA clustering algorithm. Filled circles signify cluster means (after ERDAS, 2002). 
and the convergence threshold was assigned arbitrarily to initiate the spectral separation using ISODATA algorithm. I used the clustering method for measuring spectral distance in a sequential method for iteratively classifying the pixels, redefining the criteria for each class, and reclassifying again so that the spectral distance patterns in the data gradually emerge.

\subsection{Separability analysis and class merging}

Signature separability is used as a statistical measure of distance between two signatures (ERDAS, 2002). Spectral separability analysis is useful to identify the presence of various spectral signatures within an image. I carried out statistical separability analysis among the twenty spectral clusters by computing the transformed divergence, a measure of the statistical separation between category response patterns for all pairs of classes (Lillesand et al., 2004). This statistic provides an exponentially decreasing weight to increasing distances between the classes, and reflects the covariance-weighted distance between the category means. The formula for computing transformed divergence (TD) can be explained in two steps. Divergence is denoted by $D_{i j}$ and expressed as:

$$
D_{i j}=\frac{1}{2} \cdot \operatorname{tr}\left[\left(C_{i}-C_{j}\right) \cdot\left(C_{i}^{-1}-C_{j}^{-1}\right)\right]+\frac{1}{2} \cdot \operatorname{tr}\left[\left(C_{i}^{-1}-C_{j}^{-1}\right) \cdot\left(\mu_{i}-\mu_{j}\right) \cdot\left(\mu_{i}-\mu_{j}\right)^{T}\right] \text {, }
$$

whereas Transformed Divergence $\left(T D_{i j}\right)$ is expressed as: 


$$
\mathrm{TD}_{\mathrm{ij}}=2000 \cdot\left[1-\exp \left(\frac{-\mathrm{D}_{\mathrm{ij}}}{8}\right)\right],
$$

where $i$ and $j$ are the two signatures (classes) being compared, $C_{i}$ is the covariance matrix of signature $i, \mu_{i}$ is the mean vector of signature $i, t r$ is the trace function for matrix algebra, and $T$ denotes the matrix transpose (Swain and Davis, 1978). Transformed divergence scales the divergence values to lie between 0 and 2000. Interpreting the results after applying transformed divergence requires analysis of those divergence values. A transformed divergence value of 2000 suggests excellent between-class separation, above 1900 provides good separation, whereas below 1700 reflects poor separation (Jensen, 2005).

The best average cell array matrix was determined by considering all three bands simultaneously. Pairs of classes whose transformed divergence values were less than 1700 were merged to form a new class, as the pairs of spectral classes are similar and belong to the same landcover category. Applying this merging procedure to the initial twenty classes resulted in six spectrally separable clusters. As shown in Table 4.1, included among the six spectral clusters are two clusters of sand, two clusters of bedrock, one cluster of vegetation, and one cluster of unclassified data, as determined by overlaying the clusters of pixels onto the color aerial photograph.

Further, a dendrogram was generated to visualize the hierarchical relationship among the spectral classes (Fig. 4.3). The spectral merging was performed by obeying the interrelationship among different spectral classes as visualized from the dendrogram, and simultaneously comparing the hierarchy of the dendrogram with the transformed divergence values between pairs of classes as obtained from the cell array matrices. 
Table 4.1 Mean spectral signature values for the six inseparable spectral clusters.

\begin{tabular}{|c|c|c|c|c|c|c|}
\hline \multirow{2}{*}{ Landcover Types } & \multicolumn{4}{|c|}{ Spectral Signatures (Scale 0 to 255) } \\
\cline { 2 - 7 } & \multicolumn{2}{|c|}{ Red Band } & \multicolumn{2}{|c|}{ Green Band } & \multicolumn{2}{c|}{ Blue Band } \\
\cline { 2 - 7 } & Mean & $\begin{array}{c}\text { Standard } \\
\text { Deviation }\end{array}$ & Mean & $\begin{array}{c}\text { Standard } \\
\text { Deviation }\end{array}$ & Mean & $\begin{array}{c}\text { Standard } \\
\text { Deviation }\end{array}$ \\
\hline Class-1 (Data, Outside the Area of Interest) & 0.04 & 1.27 & 0.02 & 0.48 & 0.02 & 0.48 \\
\hline Class-10 (Sand Deposits-2) & 148.79 & 3.20 & 131.71 & 3.27 & 102.18 & 3.27 \\
\hline Classes-19,20 (Bare Bedrock-2) & 165.70 & 3.42 & 161.72 & 4.02 & 138.81 & 4.02 \\
\hline Classes-2,3,4,5 (Vegetation) & 100.34 & 19.60 & 82.14 & 19.71 & 61.83 & 19.71 \\
\hline Classes-6,7,8,9 (Sand Deposits-1) & 138.78 & 5.43 & 120.69 & 6.19 & 95.65 & 6.19 \\
\hline Classes-11,12,13,14,15,16,17,18 (Bare Bedrock-1) & 155.35 & 5.01 & 147.34 & 7.15 & 123.34 & 7.15 \\
\hline
\end{tabular}




\section{Class-1}

Class-2

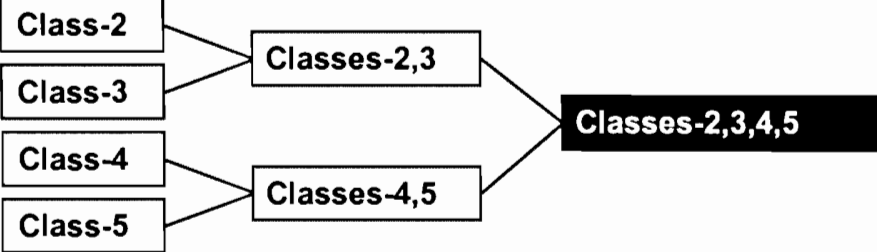

Class-6

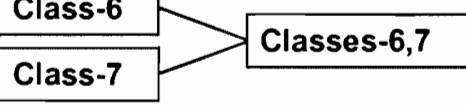

\section{Class -8}

Class -9

Class-10

Class-11

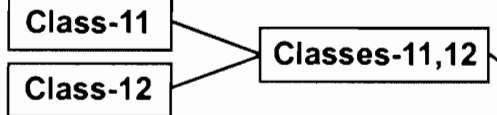

Class-13

Class-14

Class-15

Class-16

Class-17

Class-18

Class-19

Class-20
Class-1 :

Classes $-2,3,4,5$ :

Classes-6,7,8,9 :

Class-10 :

Classes-11,12,13,14,15,16,17,18 :

Classes-19,20 :
Unclassified Data

Vegetation

Sand-1

Sand-2

Bedrock-1

Bedrock-2

Figure 4.3 Starting from initial ISODATA twenty clusters, a simplified dendrogram could explain the steps of signature separability analysis, and sequential merging of spectral clusters to finally generate six inseparable clusters (denoted by filled rectangles). 
Spectral classes in the dendrogram were merged using the Euclidean distance measure and complete linkage agglomeration (Davis, 2002; ERDAS, 2002). The dendrogram portrays the six spectral classes identified as distinct clusters. The mean signature values for the six classes are plotted as a function of wavelength in Figure 4.4.

Signature objects are used to create and view graphs of signature parameters so they can be readily compared. The graphs appear as a set of ellipses on a feature space plot (Fig. 4.5). Each ellipse is centered on the mean spectral signature for a given cluster, with one standard deviation used to define the ellipse dimensions (ERDAS, 2002). The separability of the six clusters can be evaluated by the position of their respective signature ellipses. Considerable overlap of ellipses (Fig. 4.5a) implies that the clusters do not represent separate classes. On the other hand, ellipses that do not overlap (Fig. 4.5b) are a positive indicator of distinctly separate classes. The signature ellipses for the six spectral clusters derived from the aerial photograph are shown in Figure 4.6. Ellipses in the feature space plots are non-overlapping, implying separability among the clusters (Fig. 4.6). Furthermore, clusters of similar landcover (i.e., the two sand clusters and the two bedrock clusters) are in close proximity to each other.

Values of transformed divergence as compiled in the cell array matrix served as the criteria for merging the initial twenty classes. The sequential merging of classes and groups of classes occurred for divergence values less than 1700 , according to the hierarchy shown in the dendrogram of Fig. 4.3. The resulting six classes are distinctly separable based on their non-overlapping spectral signatures (Figs. 4.4 and 4.6), indicating a successful application of the clustering algorithm. Further, upon applying the maximum likelihood classification, the six spectral classes match precisely with the 
Spectral Signatures of Different Landcover Types

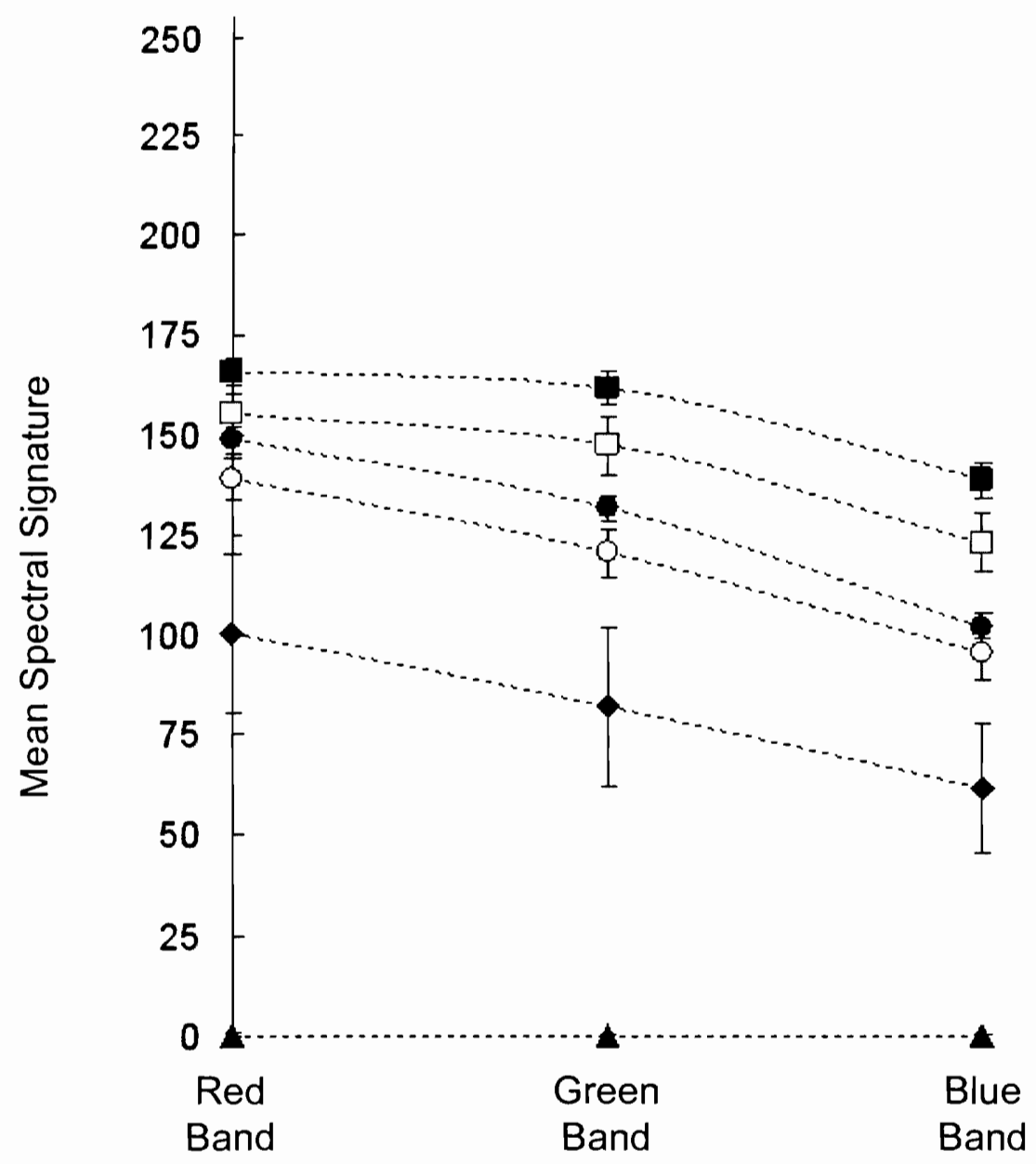

Spectral Bands

… Class-1 (Data, Outside the Area of Interest)

.... Classes-2,3,4,5 (Vegetation)

...... Classes-6,7,8,9 (Sand Deposits-1)

..... Class-10 (Sand Deposits-2)

...-... Classes-11,12,13,14,15,16,17,18 (Bare Bedrock-1)

...... Classes-19,20 (Bare Bedrock-2)

Figure 4.4 Plots of mean spectral signatures for the six separable spectral classes, derived from ISODATA clustering and sequential merging of clusters. Error bars are shown for one standard deviation. 


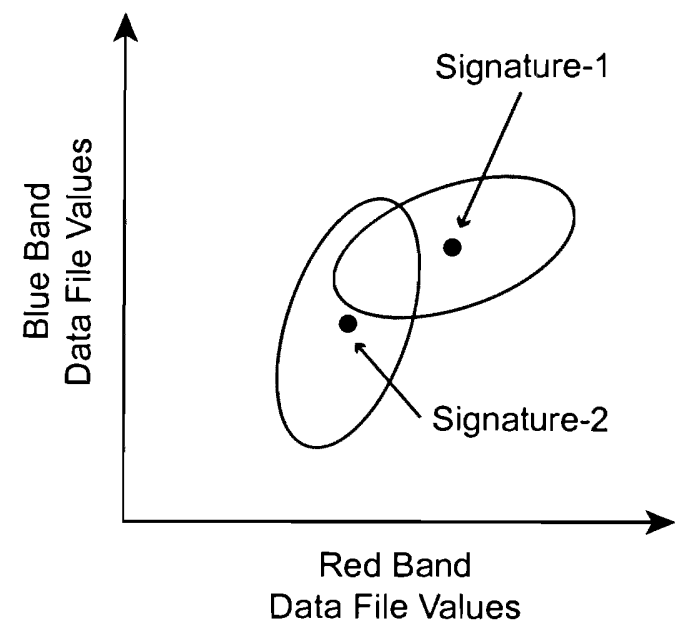

(a) Signatures Overlap

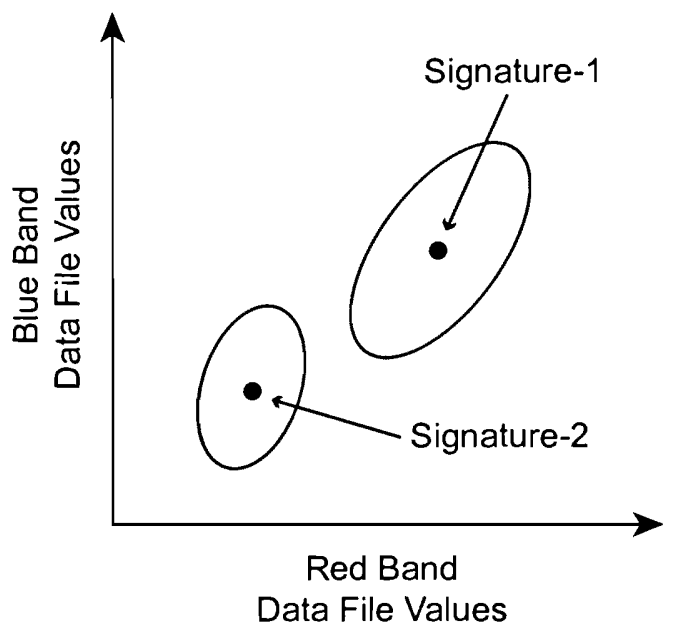

(b) Distinct Signatures

Figure 4.5 Ellipse evaluation of spectral signatures. Filled circles signify signature means. (a) Overlapping signatures, and (b) distinct signatures (after ERDAS, 2002). 

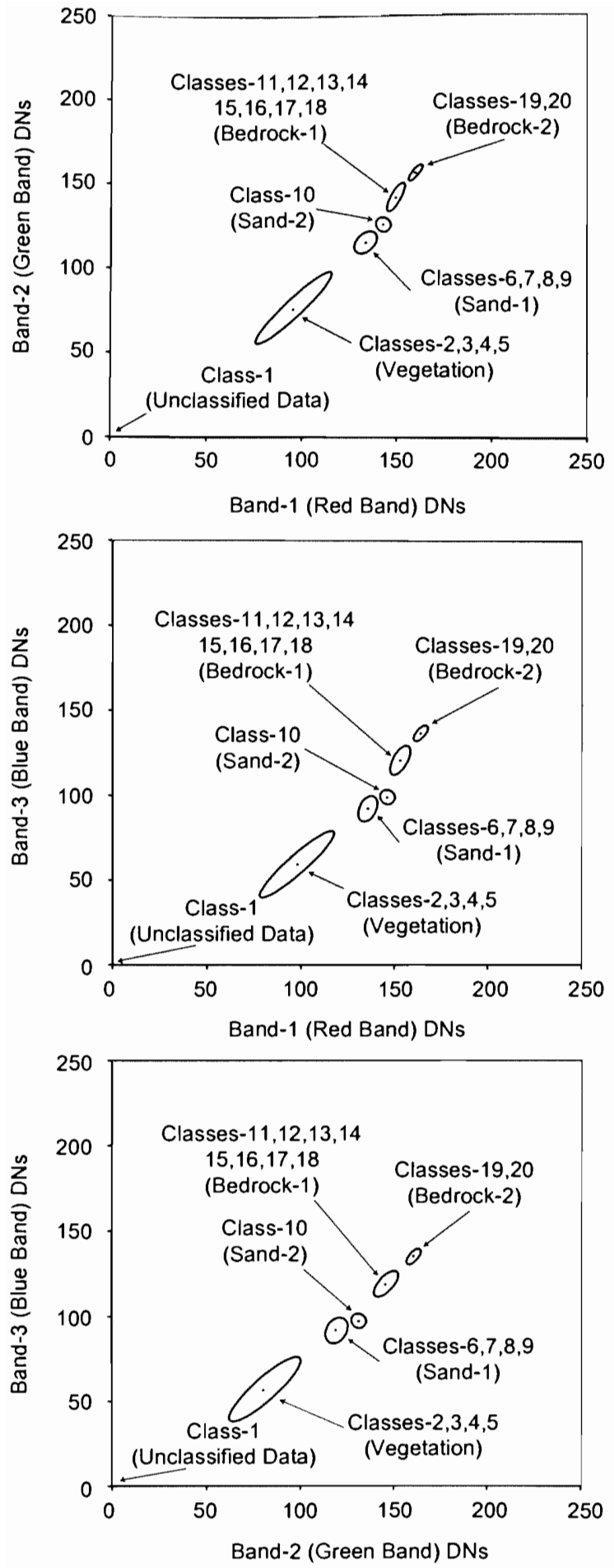

Figure 4.6 Signature separability in feature space for the six spectrally separable clusters. Filled circles signify signature means, and ellipses were drawn on the basis of one standard deviation. Note that the signature ellipses are distinct and do not overlap. 
landcover types observed in the aerial photograph, thereby verifying their information utility (Lillesand et al., 2004). Both sand and bedrock exhibit two different spectral signatures, indicating non-uniform properties for each of these landcover types (Figs. 4.4 and 4.6). This may result from non-uniform radiance (i.e., distribution of reflected sunlight) and/or slight differences in composition or weathering. Nonetheless, spectral classes belonging to the same landcover category are in close spectral proximity to each other and separated by greater spectral distances from other categories (Figs. 4.4 and 4.6), suggesting that recoding similar classes to the same landcover type is appropriate. Also noteworthy in these figures is the large spectral separation between vegetation and the other spectral classes, suggesting that vegetation can be successfully identified and distinguished from other landcover types in the image.

\subsection{Maximum likelihood classification}

The signatures of the six separable spectral clusters were then used as training data for reclassifying the area of interest using a maximum likelihood classifier. This parametric decision rule is based on the probability that a pixel belongs to a particular class, and assumes that the input bands for each class have normal distributions (Drury, 2001; ERDAS, 2002). The output image after maximum likelihood classification was thematically recoded into three major landcover categories: (i) vegetation, (ii) sand, and (iii) bedrock (Figs. 4.7 and 4.8). Class-1 was discarded as it consists of the unclassified data located outside the area of interest. All pixels from the original classes were changed 


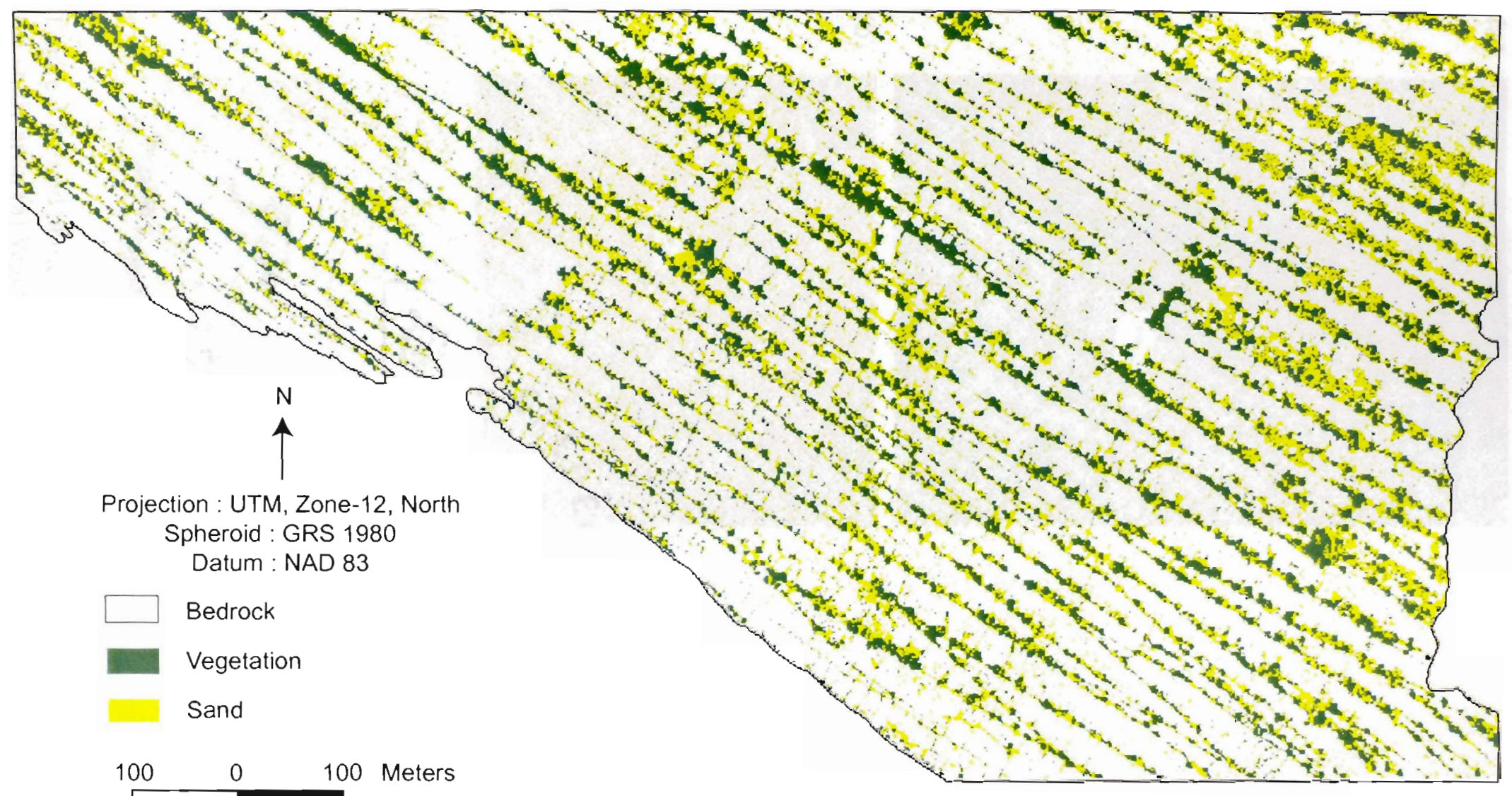

Figure 4.7 The landcover map generated after recoding of the classified aerial photograph. 
(a)

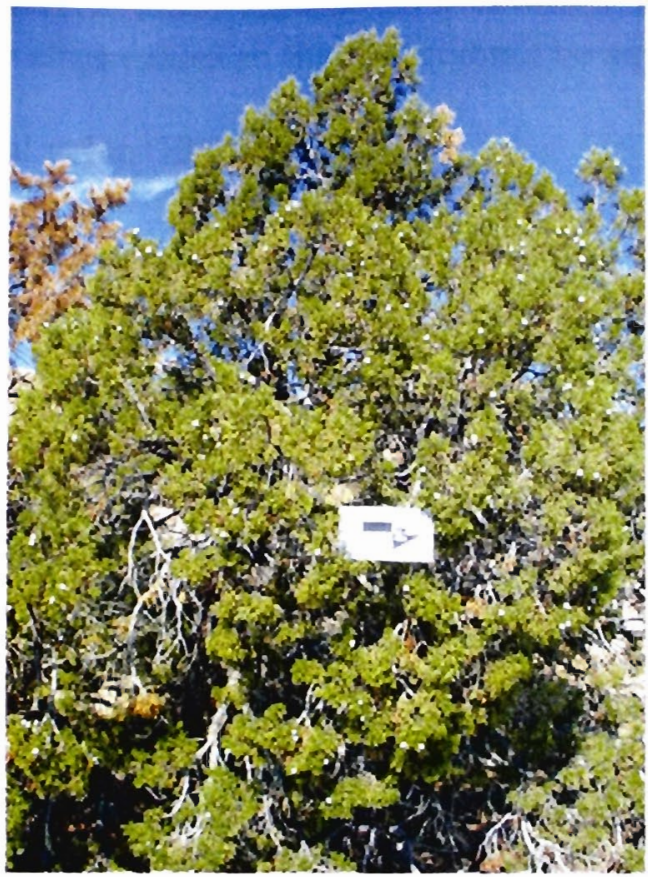

(b)

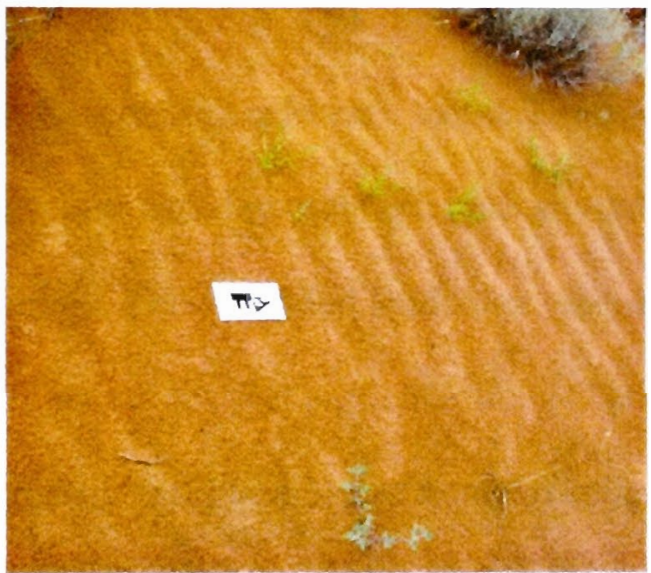

(c)

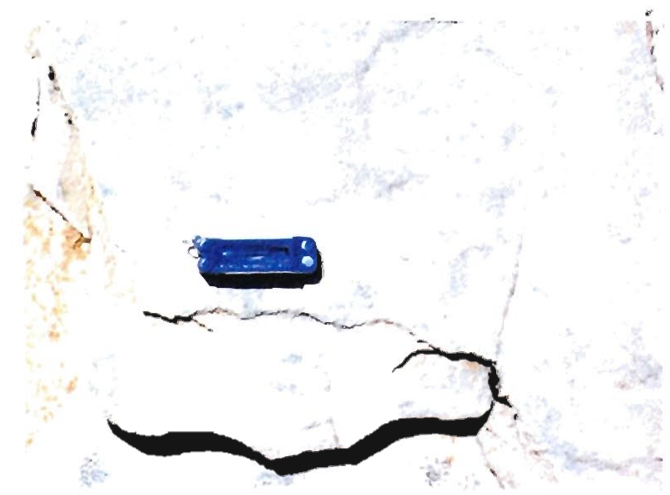

Figure 4.8 Field photographs of the three major landcover types present within the study area. (a) Vegetation (Pine and Juniper trees), (b) sand, and (c) bedrock of Moab Member of the Curtis Formation. 
to new class values so there would not be any pixels remaining in the file with the original value (ERDAS, 2002).

\subsection{Classification accuracy assessment}

The accuracy of the classification process was evaluated by comparing results of the classification to corresponding geographical data that are assumed to be true (i.e., reference data). The accuracy assessment consisted of selecting 150 random pixels proportionately distributed according to the three landcover classes (i.e., stratified random sampling, Fig. 4.9). For each pixel, the classified landcover theme was compared to its corresponding reference value. The reference dataset, in turn, consisted of the original color aerial photograph with ground-truth information obtained from the GPS field survey. The classified landcover category for a specific location was compared with the GPS record for that particular pixel (Table 4.2). The results are presented in a $3 \times 3$ "error matrix" (Table 4.3) that compares the reference class values (defined by the analyst) to the assigned class values (allocated by the computer).

Classification accuracies are given for each individual landcover class, as well as for the overall accuracy of the combined classes. The overall accuracy is calculated as the sum of the correctly classified pixels (the sum of the major diagonal, in this case 132) divided by the total number of sample pixels (150 in this case). The producer's accuracy is the probability of correctly identifying a specific landcover category for each pixel, whereas the user's accuracy measures the probability that the landcover classification actually represents the true landcover on the ground (Congalton and Green, 1999; Lo and 


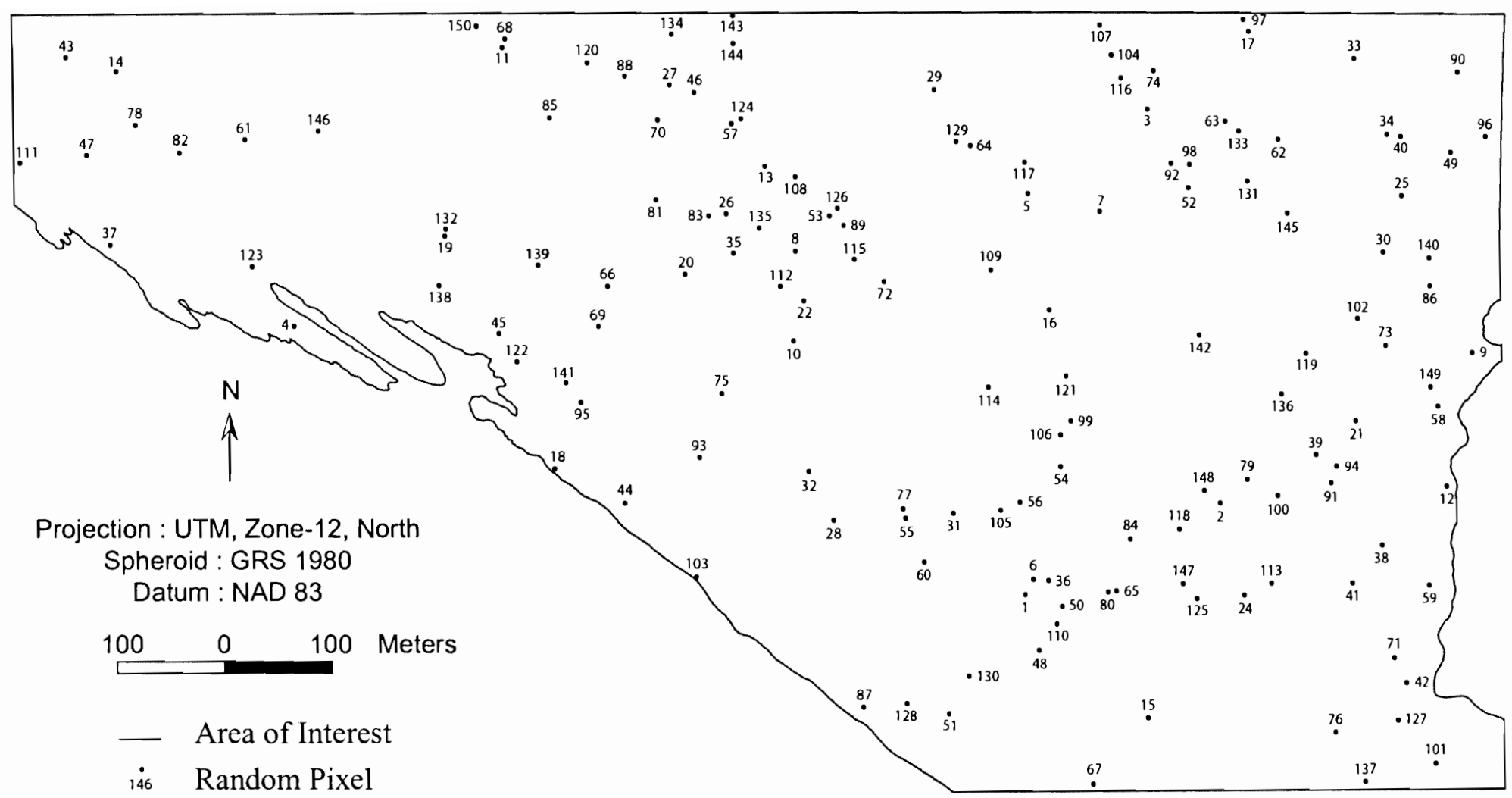

Figure 4.9 Distribution of the one hundred and fifty stratified random pixels over the area of interest, used for classification accuracy assessment. 
Table 4.2 GPS ground truth locations within the study area, and description of the individual landcover types recorded. Refer to Fig. 2.10 for their spatial distribution.

\begin{tabular}{|c|c|c|c|c|}
\hline GPS Station-ID & Latitude (D'MM.MMM') & Longitude ( ${ }^{\circ}$ MM.MMM') & Description & Classified as \\
\hline 1 & N $38^{\circ} 47.485^{\prime}$ & W $109^{\circ} 35.598^{\prime}$ & Beginning of dip slope on northeastern limb of Salt Valley Anticline & Bedrock \\
\hline 2 & N $38^{\circ} 47.439^{\prime}$ & W $109^{\circ} 35.583^{\prime}$ & Contact between Slickrock member and Moab member & Bedrock \\
\hline 3 & N $38^{\circ} 46.944^{\prime}$ & W $109^{\circ} 34.813^{\prime}$ & Standing on bedrock of Moab member & Bedrock \\
\hline 4 & N $38^{\circ} 47.512^{\prime}$ & W $109^{\circ} 35.476^{\prime}$ & Standing on outcrop of Moab member & Bedrock \\
\hline 5 & N $38^{\circ} 47.523^{\prime}$ & W $109^{\circ} 35.496^{\prime}$ & Vegetation & Vegetation \\
\hline 6 & N $38^{\circ} 47.568^{\prime}$ & W $109^{\circ} 35.517^{\prime}$ & Vegetation & Vegetation \\
\hline 7 & N $38^{\circ} 47.546^{\prime}$ & W $109^{\circ} 35.474^{\prime}$ & Standing within sand deposits, close to vegetation & Sand \\
\hline 8 & N $38^{\circ} 47.542^{\prime}$ & $\mathrm{W} 109^{\circ} 35.452^{\prime}$ & Standing on outcrop of Moab member, sand deposits in front & Bedrock \\
\hline 9 & N $38^{\circ} 47.534^{\prime}$ & W $109^{\circ} 35.408^{\prime}$ & Standing within sand deposits, in front of vegetation & Sand \\
\hline 10 & N $38^{\circ} 47.533^{\prime}$ & W $109^{\circ} 35.411^{\prime}$ & Sand deposits & Sand \\
\hline 11 & N $38^{\circ} 47.543^{\prime}$ & W $109^{\circ} 35.369^{\prime}$ & Standing on outcrop of moab member & Bedrock \\
\hline 12 & N $38^{\circ} 47.567^{\prime}$ & W $109^{\circ} 35.323^{\prime}$ & Vegetation & Vegetation \\
\hline 13 & N $38^{\circ} 47.598^{\prime}$ & W $109^{\circ} 35.296^{\prime}$ & Standing on outcrop of Moab member, close to vegetation & Bedrock \\
\hline 14 & N $38^{\circ} 47.634^{\prime}$ & W $109^{\circ} 35.315^{\prime}$ & Standing on bedrock of Moab member & Bedrock \\
\hline 15 & N $38^{\circ} 47.657^{\prime}$ & W $109^{\circ} 35.374^{\prime}$ & Sand deposits & Sand \\
\hline 16 & N $38^{\circ} 47.810^{\prime}$ & W $109^{\circ} 35.308^{\prime}$ & Standing very close to open systematic joint & Bedrock \\
\hline 17 & N $38^{\circ} 47.818^{\prime}$ & W $109^{\circ} 35.332^{\prime}$ & Standing in front of vegetation & Vegetation \\
\hline
\end{tabular}


Table 4.3 Error matrix (a) and classification accuracies (b) derived from the accuracy assessment of the landcover classification. User's accuracy and producer's accuracy for individual landcover type is calculated. Kappa statistic for each category is computed (c).

(a) Error Matrix:

\begin{tabular}{|c|c|c|c|c|}
\cline { 2 - 5 } \multicolumn{1}{c|}{} & \multicolumn{3}{c|}{ Reference Data } & Row Total \\
\hline Classified Data & Vegetation & Sand & Bedrock & 26 \\
\hline Vegetation & 20 & 3 & 3 & 30 \\
\hline Sand & 1 & 19 & 10 & 94 \\
\hline Bedrock & 0 & 1 & 93 & 150 \\
\hline Column Total & 21 & 23 & 106 & \\
\hline
\end{tabular}

(b) Accuracy Totals:

\begin{tabular}{|c|c|c|c|c|c|}
\hline Class Name & Reference Totals & Classified Totals & Number Correct & Producer's Accuracy (\%) & User's Accuracy (\%) \\
\hline Vegetation & 21 & 26 & 20 & 95.2 & 76.9 \\
\hline Sand & 23 & 30 & 19 & 82.6 & 63.3 \\
\hline Bedrock & 106 & 94 & 93 & 87.7 & 98.9 \\
\hline Totals & 150 & 150 & 132 & \multicolumn{2}{l}{} \\
\cline { 1 - 5 }
\end{tabular}

Overall Classification Accuracy: $88.0 \%$

(c) Kappa Statistics:

\begin{tabular}{|c|c|}
\hline \multicolumn{2}{|c|}{ Conditional Kappa for Each Category } \\
\hline Class Name & Kappa \\
\hline Vegetation & 0.73 \\
\hline Sand & 0.57 \\
\hline Bedrock & 0.96 \\
\hline
\end{tabular}

Overall Kappa Statistic: 0.76 
Yeung, 2002). The kappa coefficient (Cohen, 1960; Rosenfield and Fitzpatrick-Lins, 1986; Congalton, 1991; Congalton and Green, 1999) expresses the proportionate reduction in error generated by a classification process compared with the error of a completely random classification (ERDAS, 2002). For this landcover classification, the overall accuracy assessment is $88 \%$ with an overall kappa coefficient of 0.76 (Table 4.3).

The accuracy of the landcover classification was assessed by comparing 150 pixels selected according to the "stratified random" procedure. This weighted distribution of test pixels is justified by the non-uniform distribution of landcover types in the classified map (Fig. 4.9). Consequently, 94 test pixels are distributed over classified bedrock, 30 pixels over classified sand, and 26 pixels scattered over areas classified as vegetation (Tables 4.3).

Classification accuracy can be evaluated both in terms of the overall map (considering all landcover types together) and in terms of each landcover type. The overall classification accuracy of $88 \%$ and overall kappa statistic of 0.76 compare favorably with results from similar studies of aerial photographs published in the literature (Harvey and Hill, 2001; Schiewe and Ehlers, 2005; Zhou \& Robson, 2001). Out of the 26 pixels classified by the software as vegetation, only five were misclassified, resulting in a producer's accuracy of $95.2 \%$, a user's accuracy of $76.9 \%$ and a kappa statistic of 0.73 (Table 4.3). Seven of the 30 pixels identified by the software as sand were classified incorrectly, resulting in a producer's accuracy of $82.6 \%$, a user's accuracy of $63.3 \%$ and a kappa statistic of 0.57 (Table 4.3 ). The classification procedure underestimated the number of bedrock pixels by 12 , resulting in a producer's accuracy of $87.7 \%$, a user's accuracy of $98.9 \%$ and a kappa statistic of 0.96 (Table 4.3 ). 
Results from this study may be compared to a compilation of published accuracy assessments listed in Table 4.4. The table contains a variety of data sources including aerial photographs, ground photographs, and imagery from satellites and other airborne sensors. Results are presented in terms of overall accuracies, as well as accuracies for the classification of vegetation, which is of particular interest for this study. As noted above, the overall accuracy of the classified map from Arches National Park (this study) is within the range of acceptable results (Table 4.4). Furthermore, the classification of vegetation in this study can be considered successful, in light of the comparable results reported in the literature (Table 4.4).

\subsection{Results}

The classification procedures used to generate the landcover map involved numerous steps, as indicated in the summary flow chart (Fig. 4.10). The process can be generalized into four main tasks: (1) cluster analysis that yields spectrally distinct classes; (2) reclassification of the image according to the results of the cluster analysis; (3) recoding the map into appropriate landcover categories; and (4) assessing the accuracy of the classification. The success of the unsupervised classification ultimately hinges upon the results of the cluster analysis, both in terms of the criteria used to merge individual clusters as well as the degree of separation among the classes.

The landcover map is the product of recoding the output of maximum likelihood classification into three categories: vegetation, sand and bedrock (Figs. 4.7 and 4.8 ). The 
Table 4.4 Compilation of published accuracy assessments reported in the literature.

\begin{tabular}{|c|c|c|c|c|c|c|}
\hline \multirow[b]{2}{*}{ Type of Data } & \multirow[b]{2}{*}{ Reference } & \multirow{2}{*}{$\begin{array}{c}\text { No. of } \\
\text { Classes }\end{array}$} & \multicolumn{2}{|c|}{ Overall } & \multicolumn{2}{|c|}{ Vegetation } \\
\hline & & & $\begin{array}{l}\text { Classification } \\
\text { Accuracy (\%) }\end{array}$ & $\begin{array}{l}\text { Kappa } \\
\text { Statistics }\end{array}$ & $\begin{array}{c}\text { Accuracy } \\
(\%)\end{array}$ & $\begin{array}{c}\text { Kappa } \\
\text { Statistics }\end{array}$ \\
\hline Aerial Photograph & This Study & 3 & 88.0 & 0.76 & $76.9-95.2$ & 0.73 \\
\hline Aerial Photograph & Harvey and Hill, 2001 & 14 & 89.0 & - & $\begin{array}{c}84.5 \pm 6.5- \\
99.0 \pm 0.1\end{array}$ & - \\
\hline Aerial Photograph & Taylor et al., 2000 & 6 & 98.0 & - & 95.0 & - \\
\hline $\begin{array}{c}\text { High Resolution } \\
\text { Airborne Stereo } \\
\text { Camera Photograph }\end{array}$ & Schiewe and Ehlers, 2005 & 4 & 68.0 & - & - & 0.78 \\
\hline Ground Photograph & Zhou and Robson, 2001 & 1 & $68.0-99.7$ & $0.36-0.99$ & $68.0-99.7$ & $0.36-0.99$ \\
\hline IKONOS & Wang et al., 2004 & 7 & $80.4-91.4$ & $0.73-0.94$ & $71.0-78.0$ & - \\
\hline $\begin{array}{c}\text { IKONOS, Quickbird, } \\
\text { SPOT 5, Orbview }\end{array}$ & Puissant et al., 2005 & 7 & $87.8-94.1$ & $0.86-0.92$ & - & - \\
\hline AVIRIS & Ernst et al., 2003 & 6 & 81.0 & 0.74 & - & - \\
\hline AVHRR & Maxwell et al., 2002 & 14 & $68.5-82.0$ & $0.66-0.81$ & - & $0.76-0.85$ \\
\hline $\begin{array}{l}\text { Airborne Imaging } \\
\text { Spectro-Radiometer }\end{array}$ & Salem et al., 2005 & 6 & 87.7 & 0.85 & - & - \\
\hline Landsat TM & Özkan and Sunar Erbek, 2005 & 6 & $42.5-85.0$ & - & 85.4 & - \\
\hline Landsat TM & Guild et al., 2004 & 17 & $68.4-79.3$ & $0.66-0.78$ & $68.4-79.3$ & $0.66-0.78$ \\
\hline Landsat TM & Peddle et al., 2004 & 16 & $85.3-91.2$ & $0.83-0.90$ & $85.3-91.2$ & $0.83-0.90$ \\
\hline Landsat TM & Nackaerts et al., 2004 & 11 & - & $0.47-0.87$ & - & - \\
\hline Landsat TM & Van Coillie et al., 2004 & 13 & - & $0.74-0.78$ & - & - \\
\hline Landsat ETM+ & Emerson et al., 2005 & 5 & 67.1 & - & $57.1-91.8$ & - \\
\hline Landsat TM, SPOT & Olthof et al., 2005 & 46 & $40.7-72.6$ & $0.37-0.54$ & - & - \\
\hline Landsat TM, SPOT & Zhang, 2001 & 3 & $51.4-95.0$ & $0.54-0.85$ & $51.4-62.4$ & - \\
\hline Landsat TM, SPOT & Karathanassi et al., 2003 & 6 & $70.0-93.0$ & $0.59-0.89$ & - & - \\
\hline $\begin{array}{c}\text { ERS-SAR, Landsat } \\
\text { TM, SPOT }\end{array}$ & Chust et al., 2004 & 15 & - & $0.58-0.90$ & - & $0.65-0.98$ \\
\hline SPOT-HRV & Foody, 2005 & 3 & 84.0 & - & 84.0 & - \\
\hline SPOT-XS & Raclot et al., 2005 & 7 & 75.0 & - & - & - \\
\hline
\end{tabular}




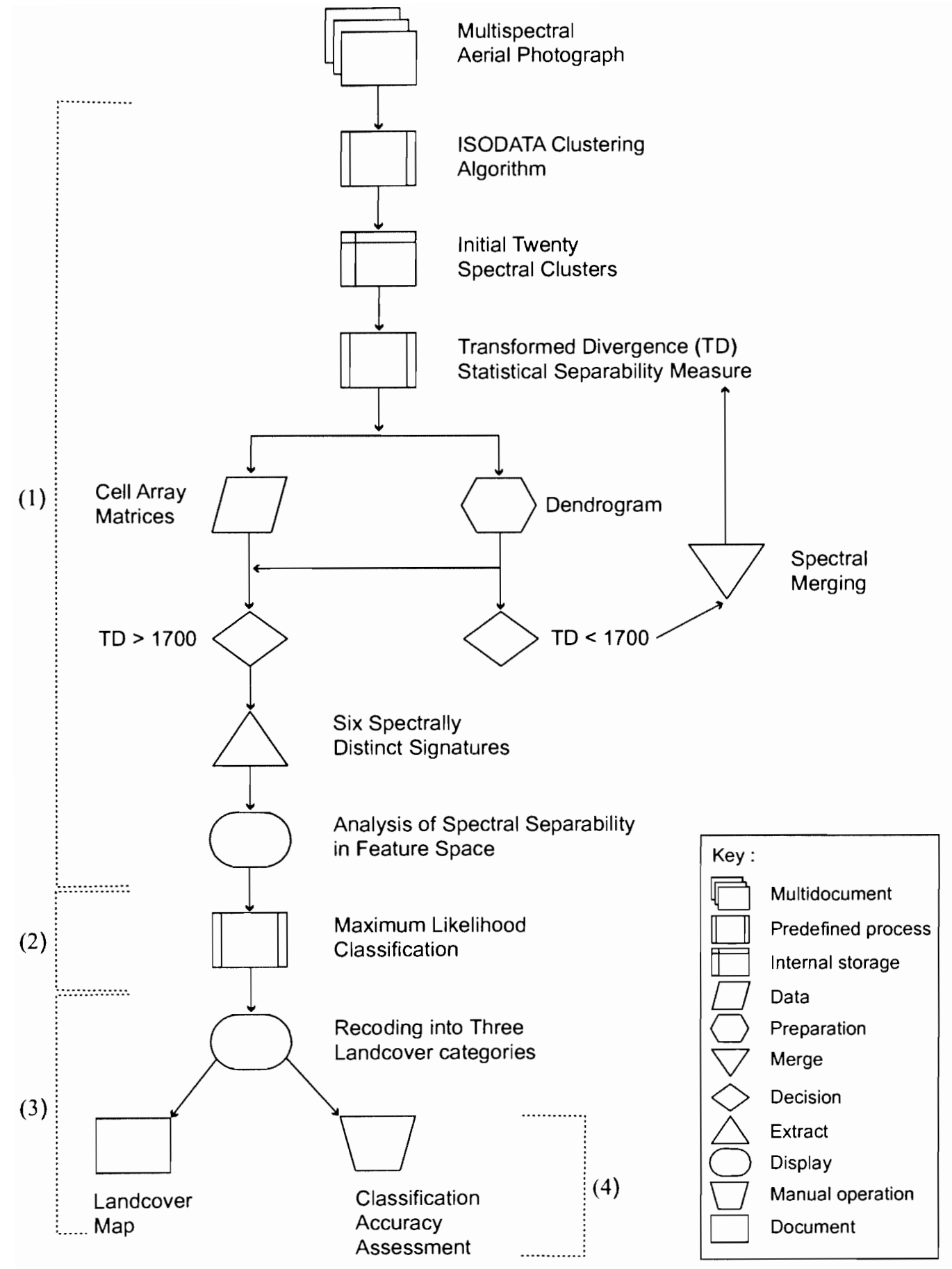

Figure 4.10 Schematic flow chart summarizing the four main tasks performed as part of the classification process. (1) Cluster analysis that yields spectrally distinct classes, (2) reclassification of the image according to the results of the cluster analysis, (3) recoding the map into appropriate landcover categories, and (4) assessing the accuracy of the classification. 
distribution of the individual landcover types in terms of relative quantities is shown in Table 4.5 and Figure 4.11 . The majority (62\%) of land surface is classified as bedrock.

Visual inspection of the landcover map reveals that vegetation appears in clusters of pixels often aligned in linear trends striking WNW-ESE, roughly parallel to the trend of the regional fold axis and the systematic joint set (Figs. 4.12a and 4.13). In many cases sand is spatially associated with vegetation. Therefore, clusters of sand are also aligned in WNW-ESE linear trends, most prominently in the central and western sections of the map (Fig. 4.12b). Sand is most abundant in the eastern portion of the map (Fig. 4.12c). 
Table 4.5 Area occupied by the three landcover types.

\begin{tabular}{|c|c|c|}
\hline Landcover Type & Area (sq.m) & $\%$ \\
\hline Vegetation & 126,808 & 17.5 \\
\hline Sand & 145,405 & 20.1 \\
\hline Bedrock & 450,579 & 62.4 \\
\hline Total Classified Area & 722,792 & 100.0 \\
\hline
\end{tabular}

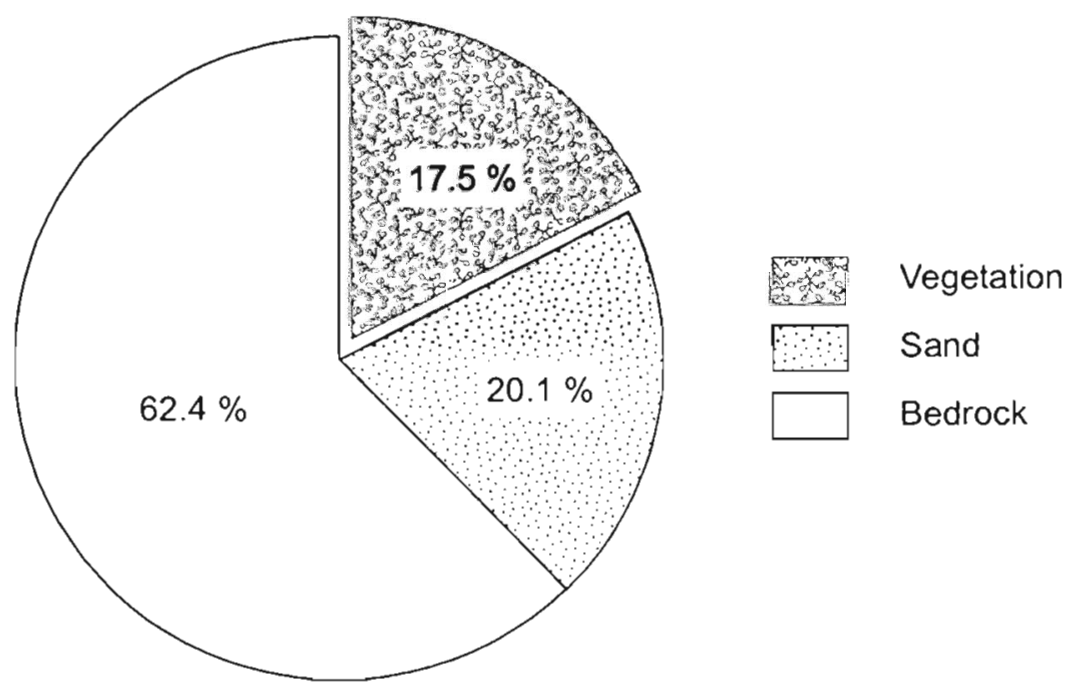

Figure 4.11 Pie chart showing distribution of different landcover categories within the area of interest. 


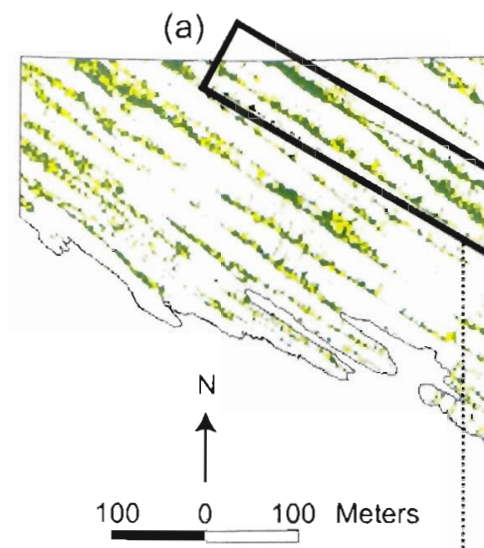

(a) Alignment of Vegetation Pixels

Vegetation

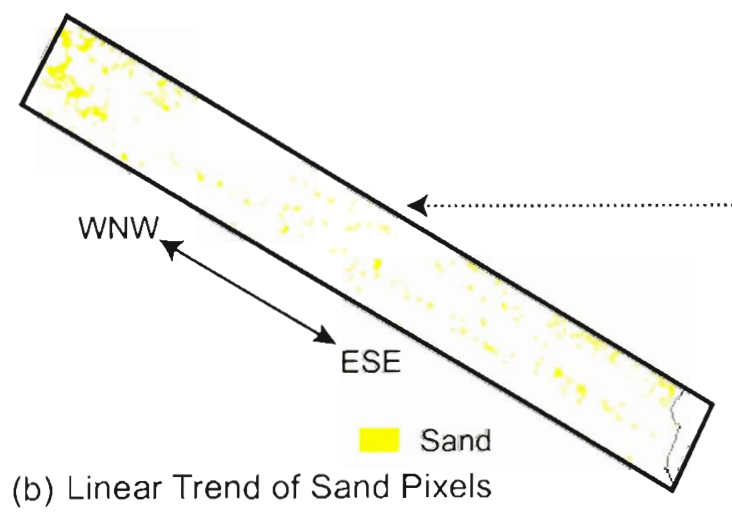

Projection : UTM, Zone-12, North

Spheroid: GRS 1980

Datum : NAD 83

Vegetation

Sand

Bedrock
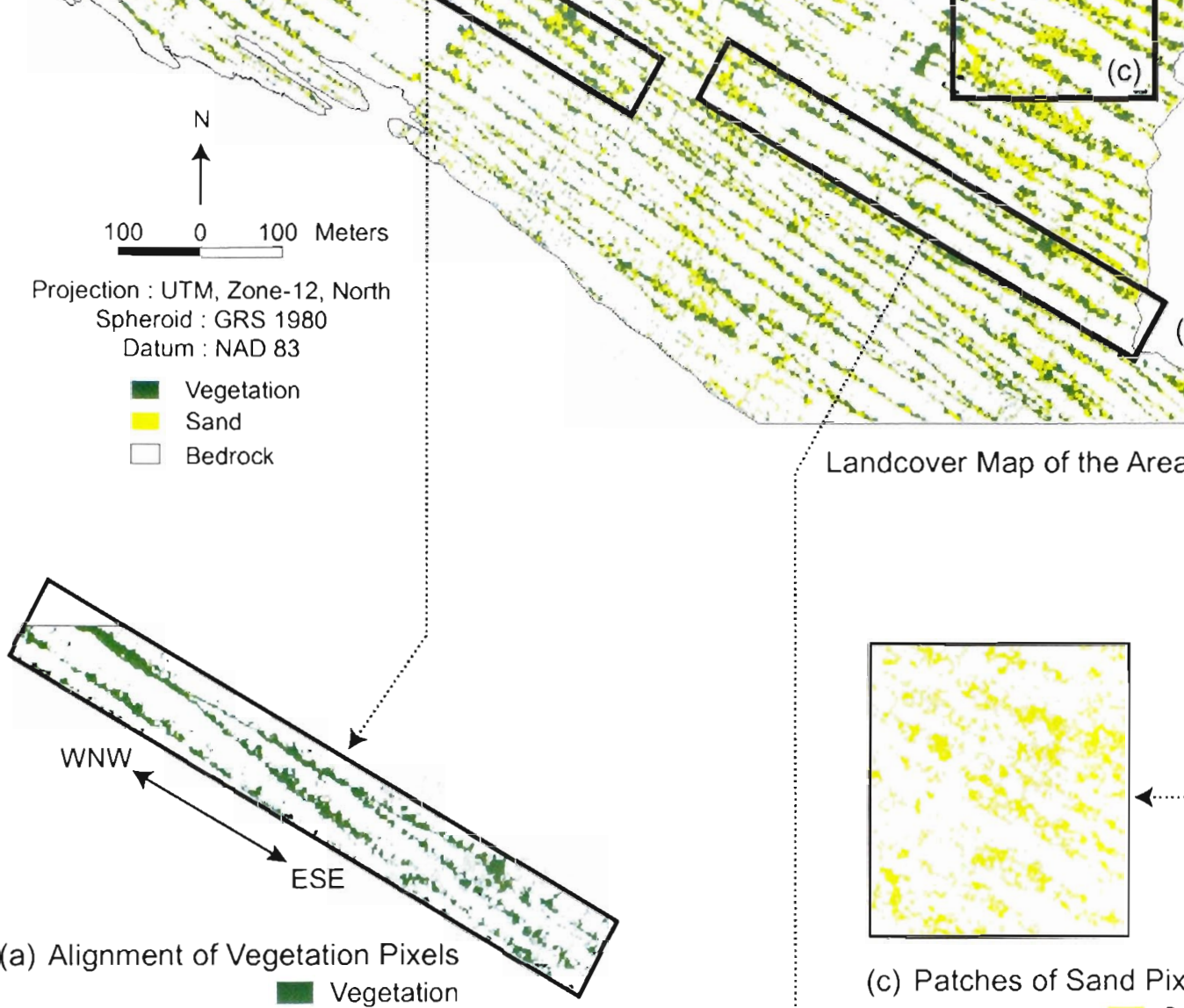

$\therefore$

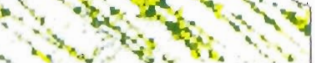

Landcover Map of the Area

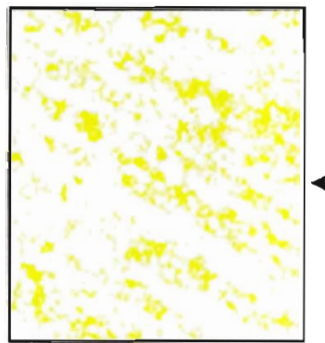

(c) Patches of Sand Pixels

Sand

Figure 4.12 Distribution of vegetation and sand pixels in the landcover map. (a) Alignment of vegetation pixels, (b) linear trend of sand pixels, and (c) patches of sand pixels. 


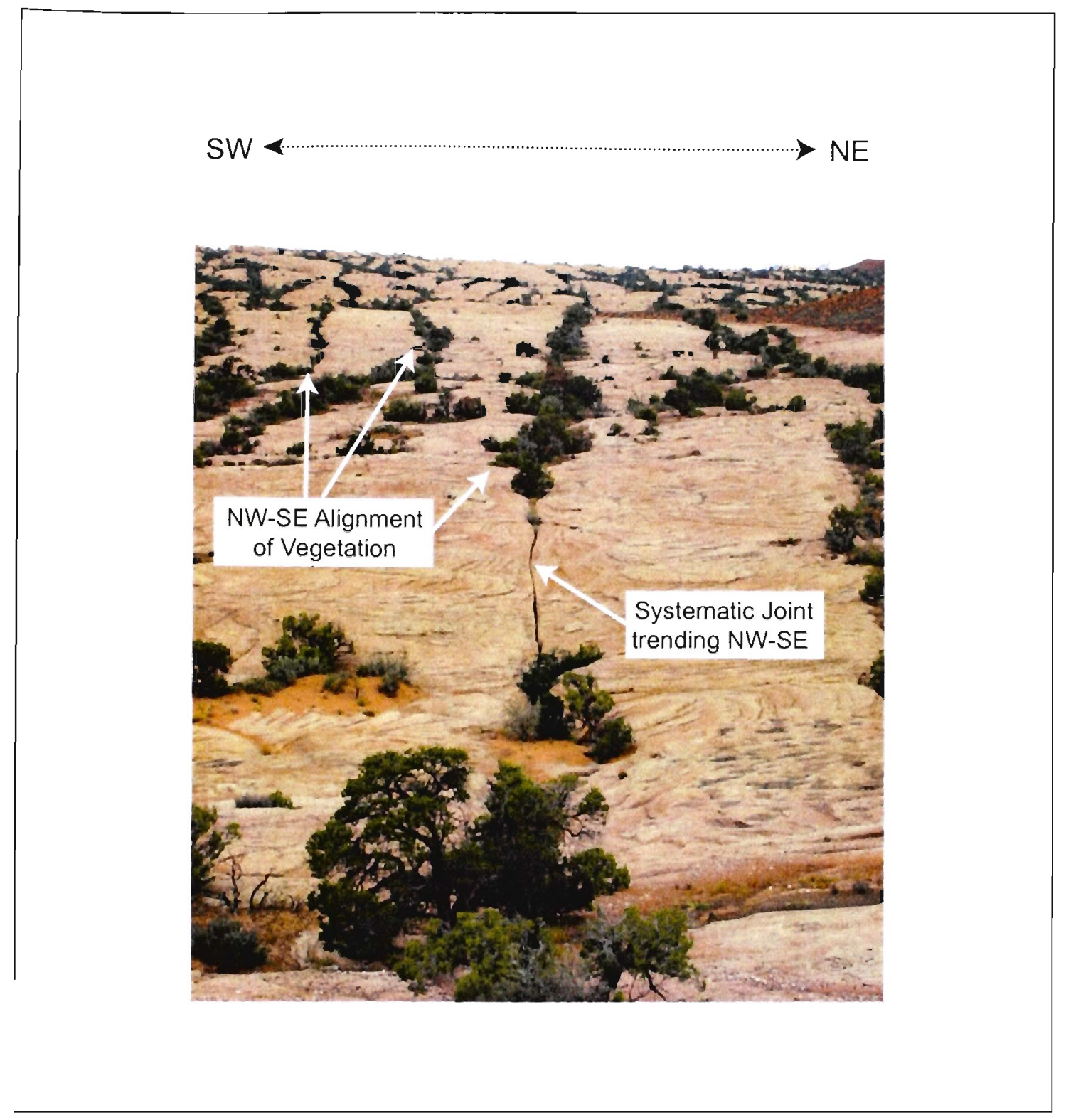

Figure 4.13 Field photograph showing alignment of vegetation in a preferred orientation (NW-SE) on the northeastern limb of the Salt Valley anticline, Arches National Park, Utah. 


\section{Chapter 5}

\section{CORRELATION ANALYSIS}

\subsection{Spatial distribution and alignment of the vegetation zones}

\subsubsection{Generation of the vegetation map}

To establish a correlation between the fracture network properties and the occurrence of vegetation, I analyzed separately the spatial distribution and alignment of vegetation in the study area. Using the ERDAS Imagine software, the vegetation pixels were isolated from the landcover image in Figure 4.7 to generate a vegetation image. This image is composed only of vegetation pixels, with the rest of the area assigned 'No Data' values (ERDAS, 2002). The vegetation image was utilized to produce a vegetation map of the study area (Fig. 5.1). In the vegetation map, the area occupied by vegetation is 126,808 sq. meters (Table 4.5). The purpose of isolating the vegetation pixels from the landcover image (Fig. 4.7) was to investigate the presence of a preferred alignment of the vegetaion pixels. However, in order to delineate an accurate trend of the alignment of vegetaion within the study area, the application of statistical filters was necessary.

\subsubsection{Focal operations and application of filters}

In order to delineate a preferred orientation of the distribution of vegetation, focal operations were carried out on the vegetation image. Filtering was performed to obtain 


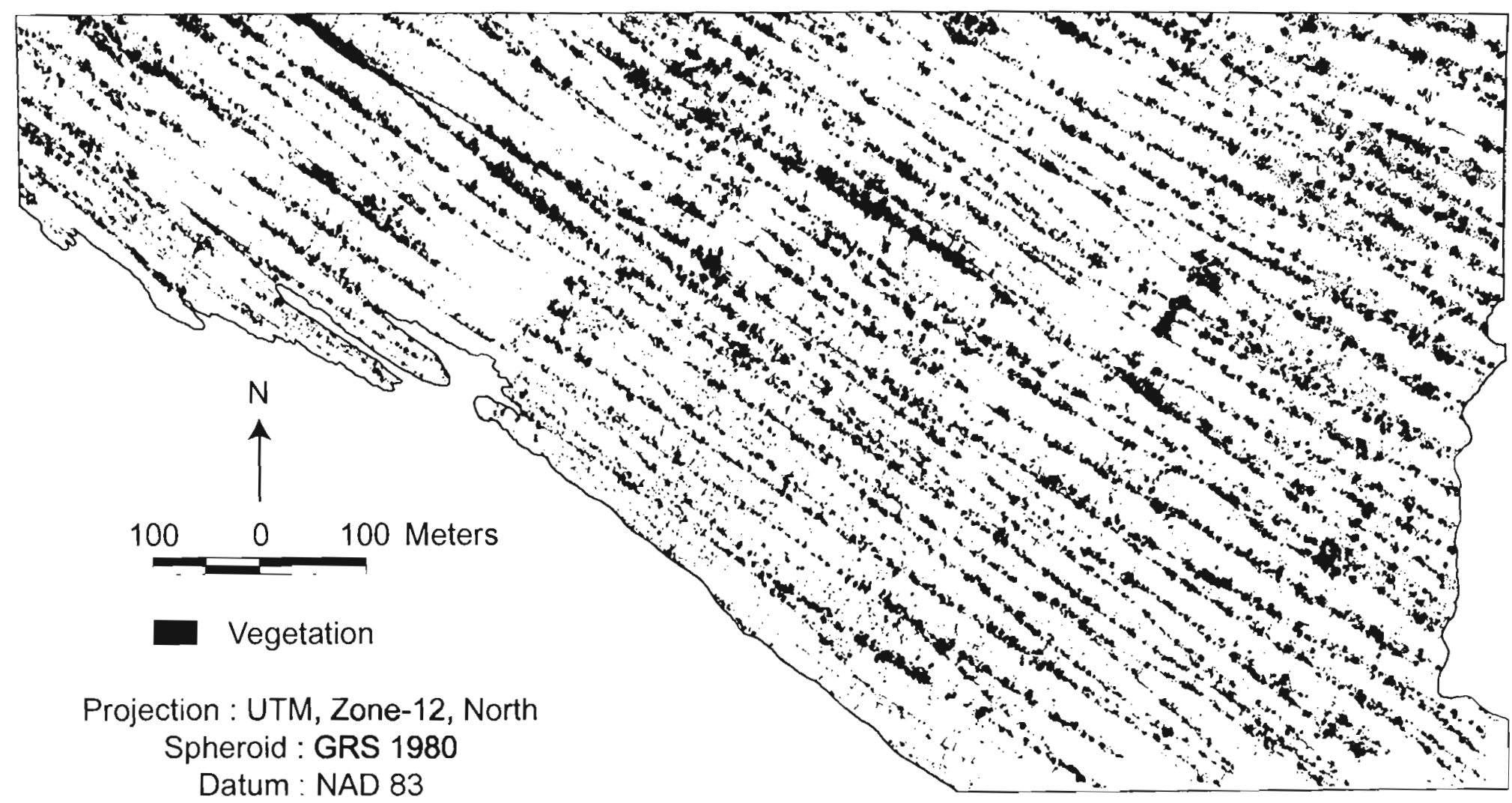

Figure 5.1 Vegetation map of the study area, as derived from the landcover map in Fig. 4.7. 
contiguous zones of vegetation pixels. I used moving windows of square kernels to calculate filtered values for each pixel in the vegetation image based on the values of the surrounding pixels (Fig. 5.2). Two kinds of square kernels were applied to the vegetation image, a $5 \times 5$ square kernel for statistical max filtering (Fig. 5.3a), and a $7 \times 7$ square kernel for statistical majority filtering (Fig. 5.3b). The max filter returned the maximum value from input pixels, whereas the majority filter returned the most commonly occurring value among the input pixels (ERDAS, 2002). After an initial application of the $5 \times 5$ statistical max filter followed by five applications of the $7 \times 7$ statistical majority filter, the vegetation pixels established a continuous linkage and displayed a preferred alignment in discrete vegetation clusters. Refer to the filtered vegetation map in Figure 5.4 , and note the continuity of vegetation from one pixel to the other eventually forming linked zones of vegetation.

A statistical max filter (Fig. 5.3a) was applied only once to avoid over estimation of vegetaion. The kernel size of five pixels was fixed by visual inspection of the distance between individual vegetation occurrences on the landcover map (Fig. 4.7). The statistical majority filter (Fig. 5.3b) required five applications in order to establish linkage and continuity between isolated vegetation pixels, so that the pixels group in discrete vegetation clusters. The kernel size of seven pixels was chosen to obtain the optimum results. 


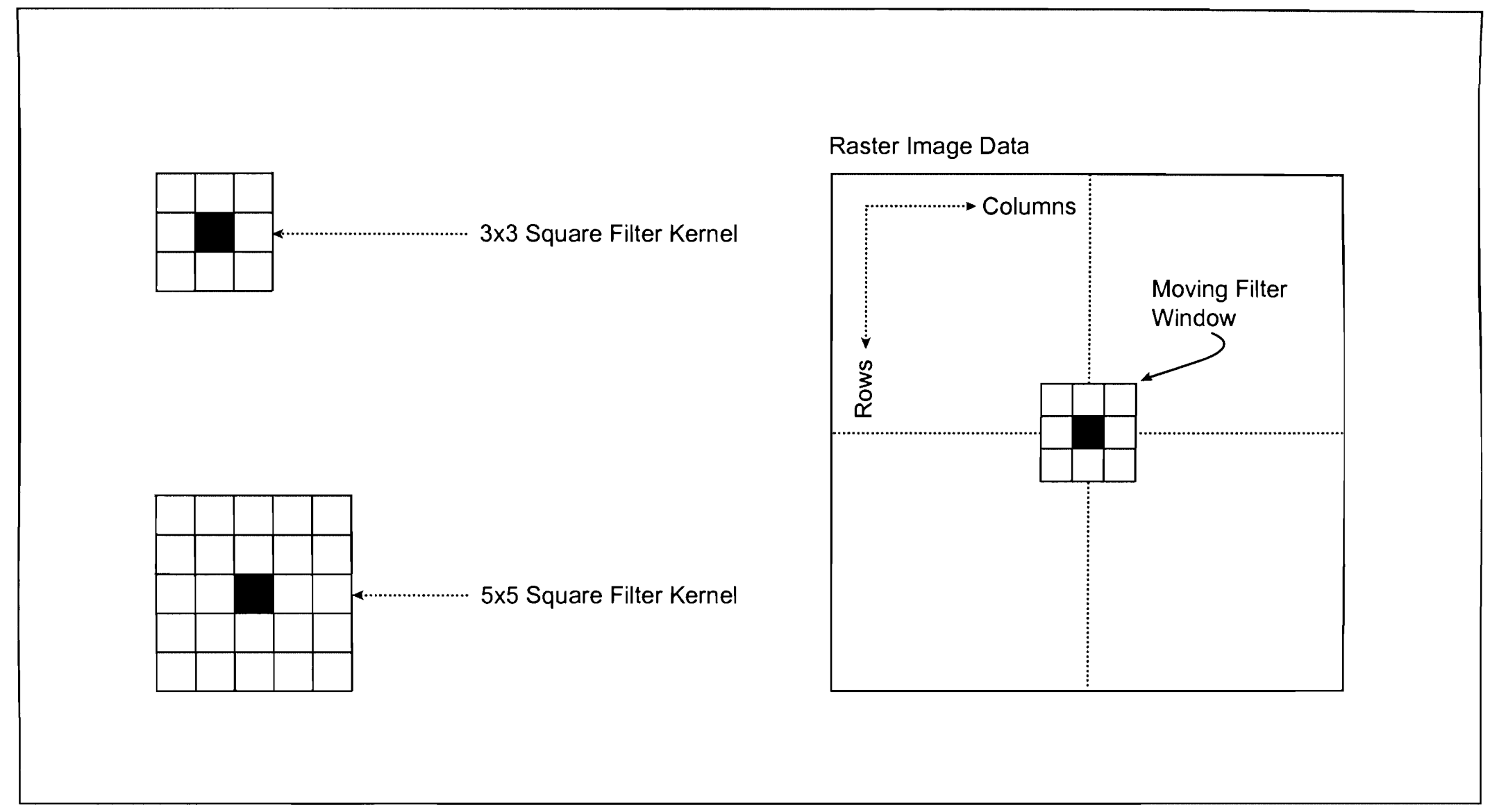

Figure 5.2 Schematic diagram explaining the principle of a focal operation. A moving filter window of a square filter kernel can be applied over the image for data reduction and/or data enhancement. 


\begin{tabular}{|c|c|c|c|c|c|c|c|c|c|c|}
\hline 0 & 0 & 1 & 0 & 0 & \multirow{2}{*}{$\begin{array}{c}\text { Statistical } 5 \times 5 \text { Square Kernel } \\
\text { Max Filtering }\end{array}$} & 0 & 0 & 1 & 0 & 0 \\
\hline 1 & 0 & 1 & 0 & 1 & & 1 & 0 & 1 & 0 & 1 \\
\hline 1 & 0 & 0 & 1 & 1 & \multirow{3}{*}{$\begin{array}{l}\text { (Returns the 'Maximum Value' in the } \\
\text { List of Input Arguments) }\end{array}$} & 1 & 0 & 1 & 1 & 1 \\
\hline 0 & 0 & 0 & 1 & 0 & & 0 & 0 & 0 & 1 & 0 \\
\hline 0 & 0 & 1 & 0 & 0 & & 0 & 0 & 1 & 0 & 0 \\
\hline
\end{tabular}

\begin{tabular}{|l|l|l|l|l|l|l|}
\hline 0 & 1 & 0 & 0 & 1 & 0 & 0 \\
\hline 0 & 0 & 1 & 1 & 0 & 0 & 0 \\
\hline 0 & 0 & 0 & 1 & 0 & 1 & 0 \\
\hline 0 & 0 & 0 & 1 & 0 & 0 & 0 \\
\hline 1 & 0 & 0 & 0 & 0 & 0 & 0 \\
\hline 0 & 0 & 0 & 1 & 1 & 0 & 0 \\
\hline 0 & 0 & 1 & 1 & 0 & 0 & 1 \\
\hline
\end{tabular}

Statistical $7 \times 7$ Square Kernel Majority Filtering

(Returns the 'Most Commonly Occurring Value' among the Given Input Values)

\begin{tabular}{|l|l|l|l|l|l|l|}
\hline 0 & 1 & 0 & 0 & 1 & 0 & 0 \\
\hline 0 & 0 & 1 & 1 & 0 & 0 & 0 \\
\hline 0 & 0 & 0 & 1 & 0 & 1 & 0 \\
\hline 0 & 0 & 0 & 0 & 0 & 0 & 0 \\
\hline 1 & 0 & 0 & 0 & 0 & 0 & 0 \\
\hline 0 & 0 & 0 & 1 & 1 & 0 & 0 \\
\hline 0 & 0 & 1 & 1 & 0 & 0 & 1 \\
\hline
\end{tabular}

Figure 5.3 Focal operations carried out on the vegetation map in Fig. 5.1. (a) Statistical $5 \times 5$ max filtering, and (b) statistical $7 \times 7$ majority filtering. ' 0 ' is a pixel with 'No Data' value, and ' 1 ' represents a vegetation pixel. 


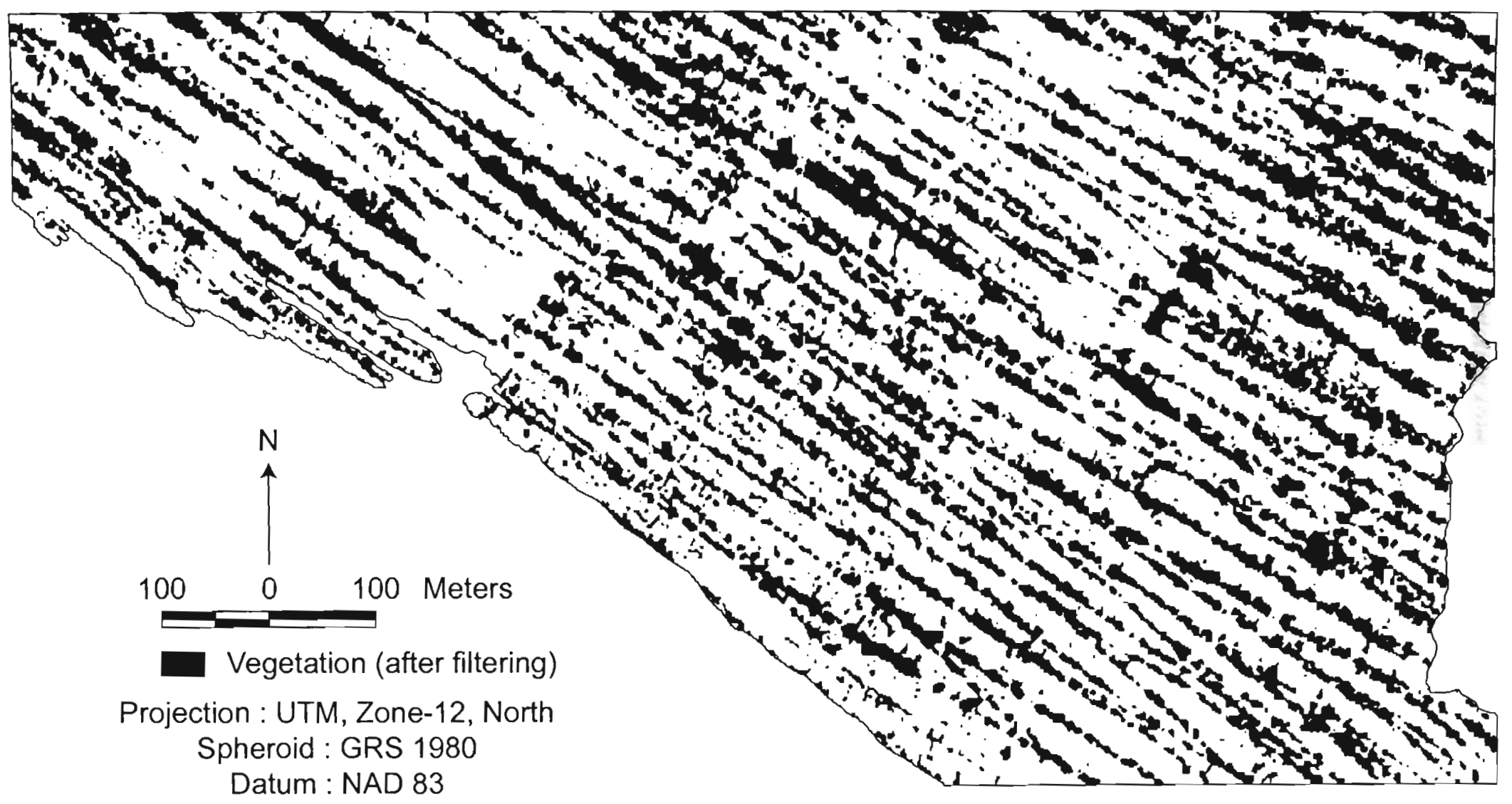

Figure 5.4 Filtered vegetation map, as obtained after application of focal operations. Note the WNW-ESE alignment of discrete vegetation zones. 


\subsubsection{Defining the vegetation zones}

The filtered vegetation image was polygonized using the 'Raster to Vector' function of the 'Vector' module of the ERDAS Imagine software. The polygons were cleaned and built in the ERDAS Imagine software (Davis, 2001; ERDAS, 2002). The vegetation in the form of vector polygons were imported into the GIS environment. Subsequently, the 'Convert to Grid' function of the ArcView GIS software was utilized to convert the vegetation polygons into a binary vegetation grid. This binary grid was composed of vegetation grid-cells of value ' 1 ', with the remaining grid cells assigned values of 'No Data' (Longley et al., 2001; ESRI, 2002). The orientations of the vegetation zones were computed using the 'Zonal Geometry' function of the 'Mila Grid Utilities' extension of the ArcView software. The mean azimuthal orientation of the vegetation zones was calculated (Fig. 5.5).

In the filtered vegetation map (Fig. 5.4), the area occupied by vegetation is 215,502 sq. meters, which is an over estimate of $70 \%$, clearly resulting from the application of filtering operations. However, application of filters can be justified for defining discrete vegetation zones and obtaining a more precise and accurate zonal geometry. The total number of vegetation zones is 1,310 . The areas occupied by the vegetation zones on the filtered map range from 0.44 sq. meter to 7,583 sq. meters, with a mean size of 165 sq. meters and a standard deviation of 508 sq. meters. The mean orientation of the vegetation zones is $125^{\circ}$ azimuth, i.e. WNW-ESE (Fig. 5.5). 


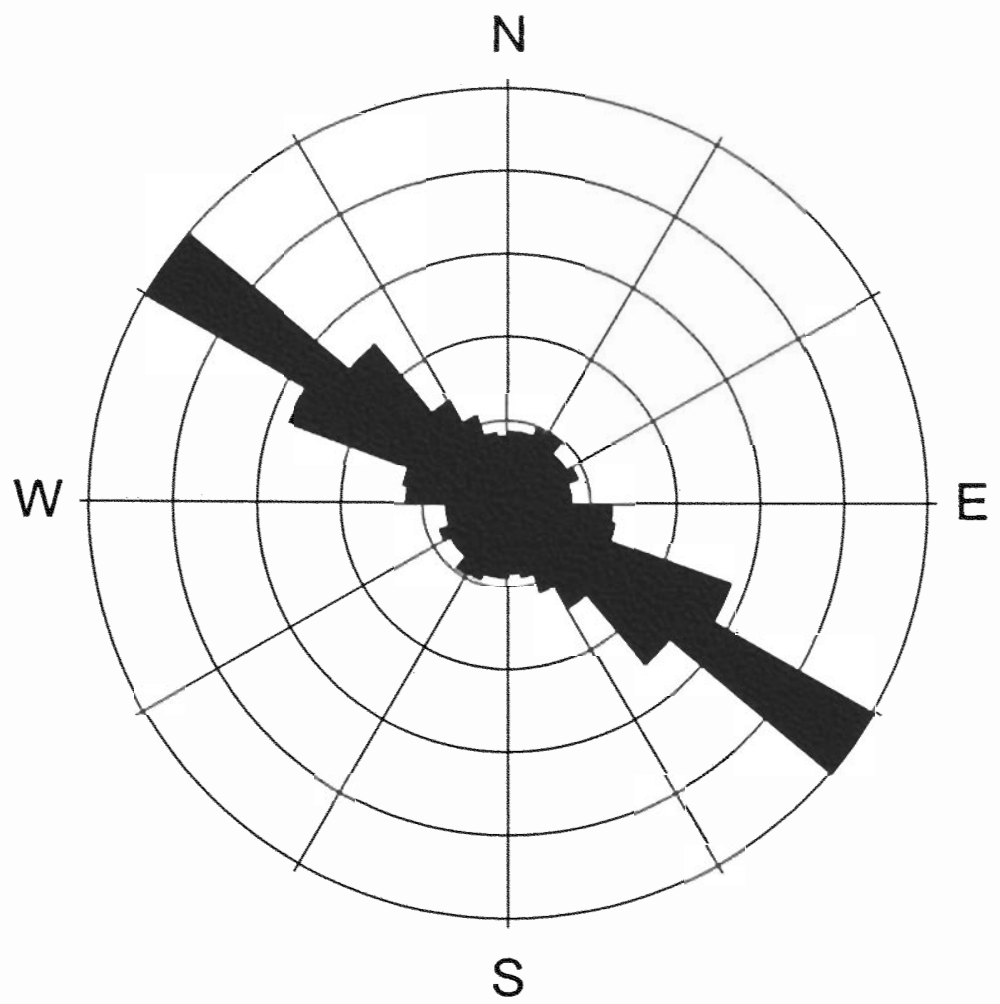

Total No. of Vegetation Zones : 1,310 Mean Trend : $125^{\circ}$

Figure 5.5 Rose diagram of the trends of the vegetation zones, as calculated from the filtered vegetation map in Fig. 5.4. Class size is 20. 


\subsection{Correlation between the fracture network properties and alignment of the}

vegetation zones

\subsubsection{Correlation between the spatial distribution of fracture traces and the spatial distribution of vegetation zones}

The J-1 set of systematic joints trends WNW-ESE (123ㅜ; Figs. 2.7, 3.2a, 3.4b), and the J-2 set of cross joints has a slightly more northerly strike $\left(128^{\circ}\right.$; Figs. $2.7,3.2 \mathrm{~b}$, $3.5 b)$. The mean orientation of the vegetation zones is nearly WNW-ESE $\left(125^{\circ}\right.$; Figs. $4.7,4.12 \mathrm{a}, 4.13,5.1,5.4,5.5)$. Hence, it can be inferred that the spatial distribution of vegetation is positively correlated and dominantly controlled by the spatial distribution of the large scale $\mathrm{J}-1$ and $\mathrm{J}-2$ sets of joints.

\subsubsection{Correlation between fracture intensity and the spatial distribution of vegetation zones}

Visual inspection of the fracture intensity maps of the $\mathrm{J}-1$ set of systematic joints (Fig. 3.17a) and the J-2 set of cross joints (Fig. 3.17b) show linear trends of high fracture intensity values in WNW-ESE and nearly NW-SE directions respectively. Nonetheless, the fracture intensity map of the entire fracture network shows linear trends of high fracture intensity values in WNW-ESE to NW-SE directions (Fig. 3.18). The mean orientation of the vegetation zones is WNW-ESE ( $125^{\circ}$; Figs. 4.7, 4.12a, 4.13, 5.1, 5.4, 5.5). Therefore, it can be concluded that the growth of vegetation is also positively 
correlated to the regions of high fracture intensity of the J-1 and J-2 sets of joints, as well as the regions of high fracture intensity within the entire fracture network. Using 'Map Calculator' function of the ArcView software, map overlay analysis was carried out between the fracture intensity map (Fig. 3.18) and the vegetation map (Fig. 5.1) to identify the common regions of high fracture intensity and occurrences of vegetation. It was found that $60 \%$ of the vegetated area is within the regions of above background ( $\geq$ 0.2/meter) fracture intensity (Fig. 5.6).

\subsubsection{Correlation between the density of the fracture intersections and the spatial distribution of vegetation zones}

The spatial distribution of fracture intersections shows linear trends in WNW-ESE to NW-SE directions (Fig. 3.22). Visual inspection of the density map of the fracture intersections also reveals regions of high fracture intensity values in WNW-ESE to NWSE directions (Fig. 3.23). The mean orientation of the vegetation zones is nearly WNWESE $\left(125^{\circ}\right.$; Figs. $\left.4.7,4.12 \mathrm{a}, 4.13,5.1,5.4,5.5\right)$. Hence, it can be inferred that the alignment of vegetation is positively correlated to the regions of high density of fracture intersections. Map overlay analysis was carried out between the map of density of fracture intersections (Fig. 3.23) and the vegetation map (Fig. 5.1) to identify the common regions of high density of fracture intersections and vegetation occurrences. It was found that $35 \%$ of the vegetated area is within the regions of above background ( $\geq$ 0.02/meter ${ }^{2}$ ) density of fracture intersections (Fig. 5.7). 


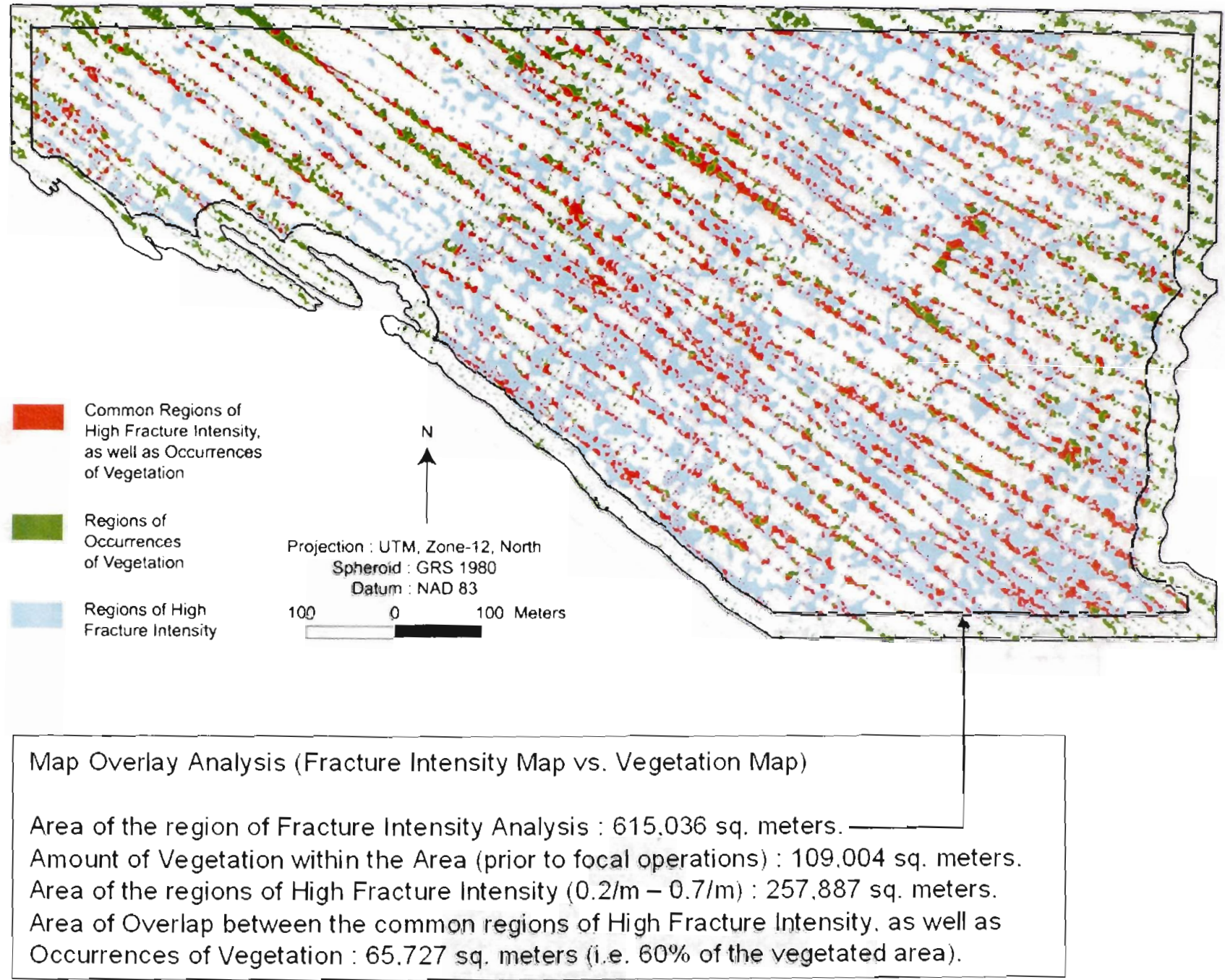

Figure 5.6 Map overlay analysis between the fracture intensity map and the vegetation map. 


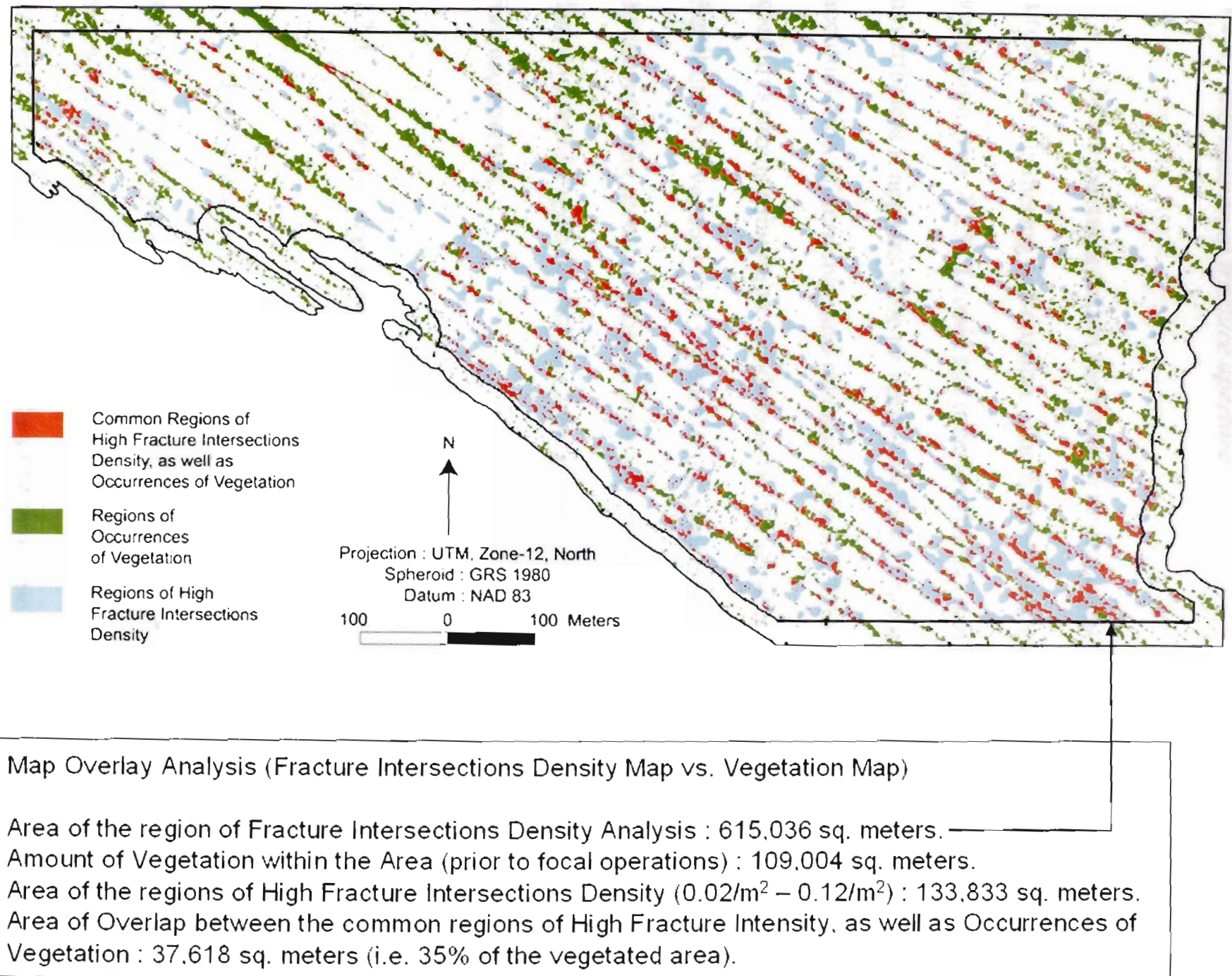

Figure 5.7 Map overlay analysis between the fracture intersections density map and the vegetation map. 


\subsubsection{Implication of fracture aperture}

Many fractures within the study area are characterized by wide apertures, which is a result of weathering and erosion. The fractures with wide apertures are concentrating vegetation (Fig. 3.25). I could not measure the fracture apertures using GIS analysis; nevertheless it appears to be an important factor for the development of soil, accumulation of nutrients, and retention of water. Hence, the fractures with wide apertures provide favorable conditions for the growth of vegetation. Although the spatial distribution of vegetation correlates to the spatial distribution of fractures (in contrast to the surrounding areas of exposed bedrock), the correlation is apparently low between the distribution of vegetation and the fracture network properties due to the variation in fracture aperture.

\subsubsection{A circular argument}

In this research, there exists a circular argument arising from digitizing fracture traces over patches of vegetation. As already mentioned in section 3.5, at places fracture traces were mapped along the vegetation to track the continuity of a single mega-scale fracture that is partly obscured by the growth of vegetation (Fig. 3.25). Hence, an argument can be raised that if fractures were traced along vegetation, then how can one correlate the distribution of fractures with that of the vegetation? To answer this argument and to overcome all ambiguity, I separately digitized segments of open fractures which are totally devoid of vegetation. I traced 73 open fracture segments that 
are not obscured by vegetation (Fig. 5.8), and calculated the mean orientation of these unequivocal fracture segments. The mean orientation of the fracture segments is $125^{\circ}$ (Fig. 5.9), which exactly matches with the WNW-ESE trend of the vegetation zones. 

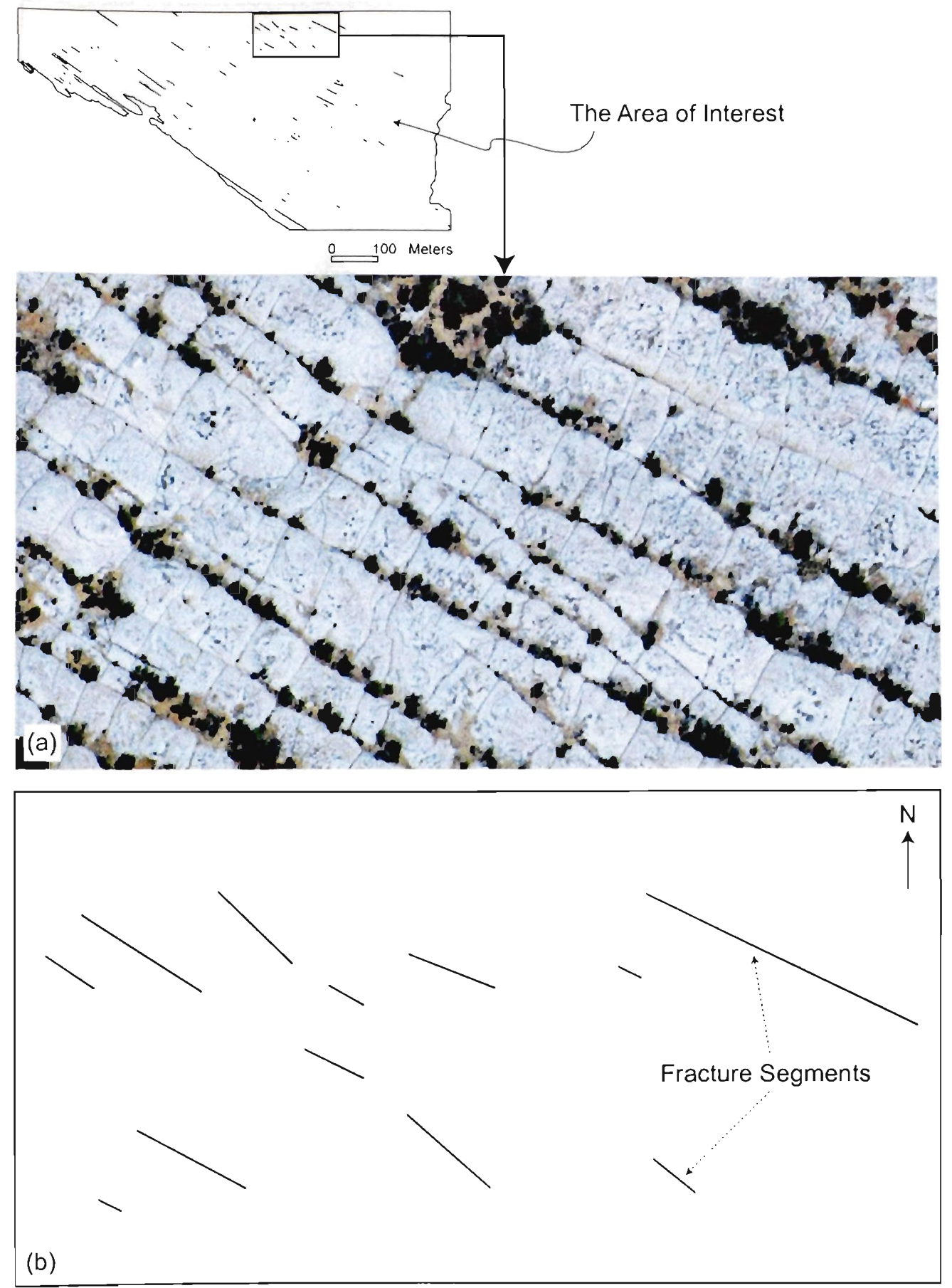

Projection : UTM, Zone-12, North Spheroid : GRS 1980

Datum : NAD 83

Figure 5.8 Traces of open fractures digitized form the color aerial photograph. (a) Aerial photograph of a region on the fractured outcrop, and (b) fracture traces mapped on the photograph along fracture segments devoid of vegetation. 


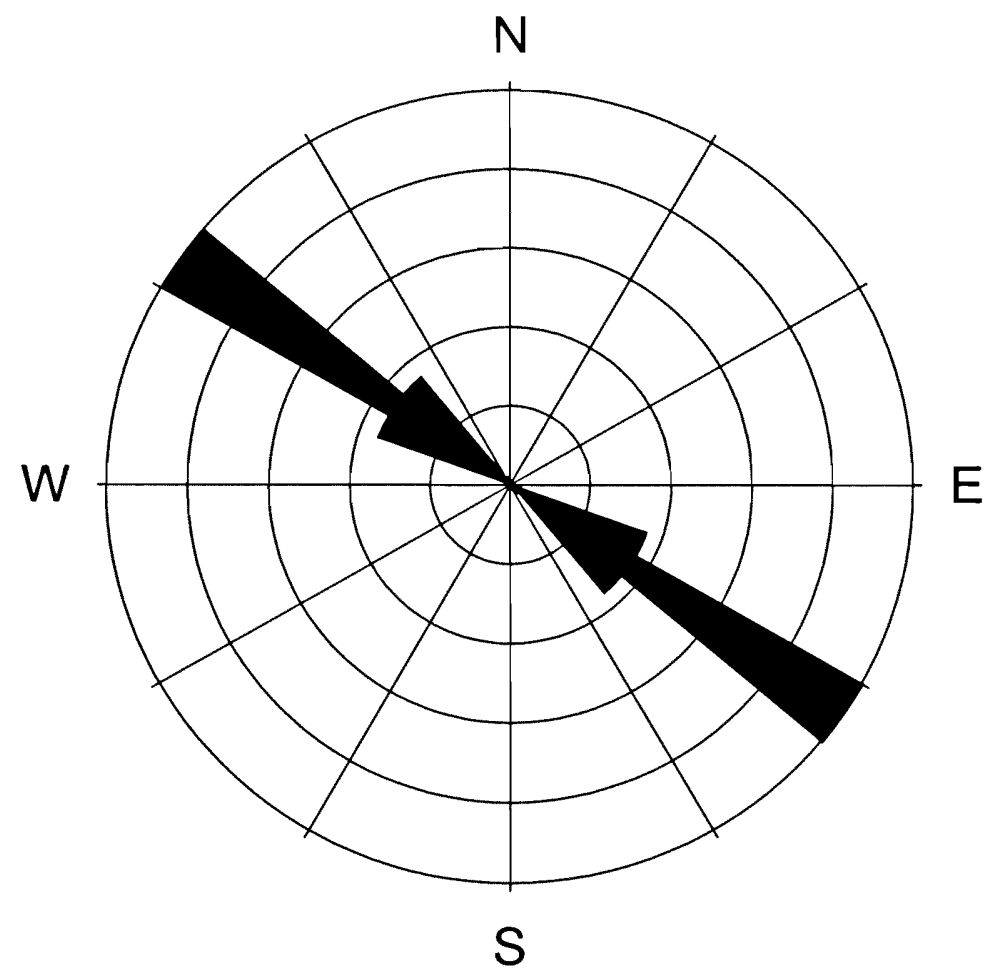

No. of Fracture Traces : 73

Mean Trend : $125^{\circ}$

Figure 5.9 Rose diagram of the trends of fracture segments, which are not obscured by vegetation. Class size is 20. 


\section{Chapter 6}

\section{SUMMARY}

The Moab Member of the Curtis Formation exposed on the limbs of Salt Valley anticline in Arches National Park, Utah encompasses excellent outcrops of mega-scale geological fractures that are unique in the entire United States. This project was developed in response to field observations of the spatial zoning of vegetation along these large-scale rock fractures. The aim of this study was to analyze and understand the spatial distribution of joint sets mapped from an aerial photograph, and to correlate the spatial heterogeneity within the fracture network with the occurrence of vegetation. Digital processing techniques were applied to classify the remotely sensed imagery, and the fracture network properties were characterized using a Geographic Information System.

In order to facilitate a comparison between fracture distribution and the occurrence of vegetation, attributes of individual sets of fractures within the fracture network were investigated, and the fracture network as a whole was studied. Fracture network properties, such as fracture length, fracture orientation, fracture spacing, proximity to fractures, fracture intensity, and the density of fracture intersections were characterized using a GIS. Further, the aerial photograph was classified in separate landcover categories to precisely identify vegetation occurrences as discrete entities. It was found that a potential correlation exists between the orientation of systematic joints and the alignment of surface vegetation. Moreover, fracture intensity and the density of fracture intersections are also positively correlated to the distribution of vegetation. To summarize, this research demonstrates the inherent spatial heterogeneity within mega- 
scale fracture networks, and the role played by fractures in sustaining the growth of desert vegetation. 


\section{REFERENCES}

Adkison, R., 2001, Utah's National Parks ( $2^{\text {nd }}$ ed.) : Wilderness Press, Berkeley, CA, 422 p.

Antonellini, M.A., and Pollard, D.D., 1995, Distinct element modeling of deformation bands in sandstone : Journal of Structural Geology, v. 17, no. 8, p. 1165-1182.

Antonellini, M.A., Aydin, A., and Pollard, D.D., 1994, Microstructure of deformation bands in porous sandstones at Arches National Park, Utah : Journal of Structural Geology, v. 16, no. 7, p. 941-959.

Baars, D.L., 1993, Canyonlands Country - Geology of Canyonlands and Arches National Parks (Revised ed.) : University of Utah Press, Salt Lake City, UT, 138 p.

Becker, A., and Gross, M.R., 1996, Mechanism for joint saturation in mechanically layered rocks - an example from southern Israel : Tectonophysics, v. 257, is. 2-4, p. 223-237.

Bonham-Carter, G.F., 1994, Geographic Information Systems for Geoscientists Modelling with GIS : Pergamon / Elsevier Science Inc., Tarrytown, NY, 398 p.

Bonnet, E., Bour, O., Odling, N.E., Davy, P., Main, I., Cowie, P., and Berkowitz, B., 2001, Scaling of fracture systems in geological media : Reviews of Geophysics, v. 39 , no. 3, p. 347-383.

Burchfiel, B.C., Cowan, D.S., and Davis, G.A., 1992, Tectonic overview of the Cordilleran orogen in the western United States in Burchfiel, B.C., Lipman, P.W., and Zoback, M.L. (eds.) : The Cordilleran Orogen - Conterminous U.S., v. G-3, The Geology of North America, The Geological Society of America, Inc., Boulder, CO, p. 407-479.

Cacas, M.C., Daniel, J.M., and Letouzey, J., 2001, Nested geological modelling of naturally fractured reservoirs : Petroleum Geoscience, v. 7, supplement (May), p. S43-S52.

Carr, J.R., 2002, Data Visualization in the Geosciences : Prentice-Hall, Inc., Upper Saddle River, NJ, 267 p.

Chilès, J.-P., and Marsily, G.de, 1993, Stochastic models of fracture systems and their use in flow and transport modeling (ch. 4) in Bear, J., Tsang, C., and Marsily, G. (eds.) : Flow and Contaminant Transport in Fractured Rock, Academic Press / Elsevier Science Inc., San Diego, CA, p 169-236. 
Chust, G., Ducrot, D., and Pretus, J. LL., 2004, Land cover discrimination potential of radar multitemporal series and optical multispectral images in a Mediterranean cultural landscape : International Journal of Remote Sensing, v. 25, no. 17, p. 3513-3528.

Clarke, K.C., 2001, Getting Started with Geographic Information Systems (3 ${ }^{\text {rd }}$ ed.) : Prentice-Hall, Inc., Upper Saddle River, NJ, 352 p.

Coburn, T.C., and Yarus, J.M. (eds.), 2000, Geographic Information Systems in Petroleum Exploration and Development : AAPG Computer Applications in Geology - No. 4, The American Association of Petroleum Geologists, Tulsa, OK, $315 \mathrm{p}$.

Cohen, J., 1960, A coefficient of agreement of nominal scales : Educational and Psychological Measurement, v. 20, no.1, p. 37-46.

Congalton, R., 1991, A review of assessing the accuracy of classifications of remotely sensed data : Remote Sensing of Environment, v. 37, p. 35-46.

Congalton, R.G., and Green, K., 1999, Assessing the Accuracy of Remotely Sensed Data - Principles and Practices : CRC Press, Inc., Boca Raton, FL, 137 p.

Crider, J.G., and Peacock, D.C.P., 2004, Initiation of brittle faults in the upper crust - a review of fold observations: Journal of Structural Geology, v. 26, is. 4, p. 691707.

Cruikshank, K.M., and Aydin, A., 1994, Role of fracture localization in arch formation, Arches National Park, Utah : Geological Society of America Bulletin, v. 106, is. 7, p. 879-891.

Cruikshank, K.M., and Aydin, A., 1995, Unweaving the joints in Entrada Sandstone, Arches National Park, Utah, U.S.A. : Journal of Structural Geology, v. 17, no. 3, p. 409-421.

Cruikshank, K.M., Zhao, G., and Johnson, A.M., 1991, Analysis of minor fractures associated with joints and faulted joints : Journal of Structural Geology, v. 13, no. 8, p. 865-886.

Cruikshank, K.M., Zhao, G., and Johnson, A.M., 1991, Duplex structures connecting fault segments in Entrada Sandstone : Journal of Structural Geology, v. 13, no. 10, p. $1185-1196$.

Davis, B.E., 2001, GIS - A Visual Approach (2 $2^{\text {nd }}$ ed.) : Onword Press / Thomson Learning, Albany, NY, $438 \mathrm{p}$. 
Davis, G.H., 1999, Structural Geology of the Colorado Plateau Region of Southern Utah, with Special Emphasis on Deformation Bands : The Geological Society of America, Inc., Special Paper no. 342, Boulder, CO, 157 p.

Davis, J.C., 2002, Statistics and Data Analysis in Geology ( $3^{\text {rd }}$ ed.) : John Wiley and Sons, Inc., New York, NY, 638 p.

DeMers, M.N., 2005, Fundamentals of Geographic Information Systems ( $3^{\text {rd }}$ ed.) : John Wiley and Sons, Inc., Hoboken, NJ, 468 p.

Dershowitz, W.S., and Einstein, H.H., 1988, Characterizing rock joint geometry with joint system models : Rock Mechanics and Rock Engineering, v. 21, no. 1, p. 2151 .

Dershowitz, W.S., and Herda, H.H., 1992, Interpretation of fracture spacing and intensity in Tillerson, J.R. and Wawersik, W.R. (eds.) : Rock Mechanics (Proceedings of the $33^{\text {rd }}$ U.S. Symposium, Santa Fe, New Mexico), Balkema, Rotterdam, p. 757766.

Doelling, H.H., 1985, Geologic Map of Arches National Park and Vicinity, Grand County, Utah : Map reference, Utah Geological and Mineral Survey, Map no. 74, Salt Lake City, UT, Canyonlands Natural History Association, Moab, UT.

Doelling, H.H., 1985, Geology of Arches National Park - To Accompany Map 74 : Utah Geological and Mineral Survey, Salt Lake City, UT, 15 p.

Doelling, H.H., 2000, Geologic road and trail guides to Arches National Park, Utah in Anderson, P.B., and Sprinkel, D.A. (eds.), 2000, Geologic Road, Trail, and Lake Guides to Utah's Parks and Monuments : CD-ROM reference, Utah Geological Association, Publication no. 29, Salt Lake City, UT.

Doelling, H.H., Oviatt, C.G., and Huntoon, P.W., 1988, Salt Deformation in the Paradox Basin : Utah Geological and Mineral Survey, Bulletin no. 122, Salt Lake City, UT, $93 \mathrm{p}$.

Drury, S., 2001, Image Interpretation in Geology ( $3^{\text {rd }}$ ed.) : Blackwell Science Inc., Malden, MA, $290 \mathrm{p}$.

Duda, R.O., Hart, P.E., and Stork, D.G., 2001, Pattern Classification : John Wiley and Sons, Inc., New York, NY, 654 p.

Dunne, W.M., and North, C.P., 1990, Orthogonal fracture systems at the limits of thrusting - an example from southwestern Wales : Journal of Structural Geology, v. 12 , is. 2 , p. $207-215$. 
Dyer, R., 1988, Using joint interactions to estimate paleostress ratios : Journal of Structural Geology, v. 10, no. 7, p. 685-699.

Ehlen, J., Hevenor, R.A., Kemeny, J.M., and Girdner, K., 1995, Fracture recognition in digital imagery in Daemen, J.J.K., and Schultz, R.A. (eds.) : Rock Mechanics (Proceedings of the $35^{\text {th }}$ U.S. Symposium, University of Nevada, Reno), Balkema, Rotterdam, p. 141-146.

Emerson, C.W., Siu-Ngan Lam, N., and Quattrochi, D.A., 2005, A comparison of local variance, fractal dimension, and Moran's I as aids to multispectral image classification : International Journal of Remote Sensing, Preview article.

ERDAS, 2002, ERDAS Field Guide ${ }^{\mathrm{TM}}\left(6^{\text {th }}\right.$ ed. $):$ ERDAS $^{\circledR}$ LLC, Atlanta, GA, 658 p.

ERDAS, 2002, ERDAS IMAGINE ${ }^{\circledR} 8.6$ - Tour Guides $^{\mathrm{T}}$ : ERDAS $^{\circledR}$ LLC, Atlanta, GA, $672 \mathrm{p}$.

Ernst, W.G., Van de Ven, C.M., and Lyon, R.J.P., 2003, Relationships among vegetation, climatic zonation, soil, and bedrock in the central White-Inyo Range, eastern California - A ground-based and remote-sensing study : Geological Society of America Bulletin, v. 115, is. 12, p. 1583-1597.

ESRI, 2002, $\operatorname{ArcMap}^{\text {TM }} 8.3$ : Software reference, Environmental Systems Research Institute, Inc., Redlands, CA.

ESRI, 2002, Using ArcGIS ${ }^{\text {TM }}$ Spatial Analyst : ESRI, Inc., Redlands, CA, 232 p.

Finn, M.D., 2000, The kinematic and structural development of throughgoing fracture zones, Monterey Formation, California : Thesis (M.S.) - Florida International University, Miami, FL, 249 p.

Foody, G.M., 2005, Local characterization of thematic classification accuracy through spatially constrained confusion matrices : International Journal of Remote Sensing, v. 26, no. 6, p. 1217-1228.

Foxford, K.A., Walsh, J.J., Watterson, J., Garden, I.R., Guscott, S.C., and Burley, S.D., 1998, Structure and content of the Moab Fault Zone, Utah, USA, and its implications for fault seal prediction in Jones, G., Fisher, Q.J., Knipe, R.J. (eds.) : Faulting, Fault Sealing and Fluid Flow in Hydrocarbon Reservoirs, The Geological Society of London, Special Publication no. 147, p. 87-103.

Garden, I.R., Guscott, S.C., Burley, S.D., Foxford, K.A., Walsh, J.J., and Marshall, J., 2001, An exhumed palaeo-hydrocarbon migration fairway in a faulted carrier system, Entrada Sandstone of SE Utah, USA : Geofluids, v. 1, is. 3, p. 195-213. 
Ghosh, K., 2003, Characterizing fracture distribution in layered rocks using Geographic Information System-based techniques : Thesis (M.S.) - Florida International University, Miami, FL, 111 p.

Gillespie, P.A., Howard, C.B., Walsh, J.J., and Watterson, J., 1993, Measurement and characterisation of spatial distribution of fractures : Tectonophysics, v. 226, is. 14, p. 113-141.

Gillespie, P.A., Johnston, J.D., Loriga, M.A., McCaffrey, K.J.W., Walsh, J.J., and Watterson, J., 1999, Influence of layering on vein systematics in line samples in McCaffrey, K.J.W., Lonergan, L., and Wilkinson, J.J. (eds.) : Fractures, Fluid Flow and Mineralization, The Geological Society of London, Special Publication no. 155 , p. $35-56$.

Gillespie, P.A., Walsh, J.J., Watterson, J., Bonson, C.G., and Manzocchi, T., 2001, Scaling relationships of joint and vein arrays from the Burren, Co. Clare, Ireland : Journal of Structural Geology, v. 23, is. 2-3, p. 183-201.

Gross, M.R., 1993, The origin and spacing of cross joints - examples from the Monterey Formation, Santa Barbara Coastline, California : Journal of Structural Geology, v. 15 , no. 6, p. 737-751.

Gross, M.R., and Engelder, T., 1995, Strain accommodated by brittle failure in adjacent units of the Monterey Formation, U.S.A. - scale effects and evidence for uniform displacement boundary conditions : Journal of Structural Geology, v. 17, no. 9, p. 1303-1318.

Gross, M.R., Fischer, M.P., Engelder, T., and Greenfield, R.J., 1995, Factors controlling joint spacing in interbedded sedimentary rocks - integrating numerical models with field observations from the Monterey Formation, USA in Ameen, M.S. (ed.) : Fractography - fracture topography as a tool in fracture mechanics and stress analysis, The Geological Society of London, Special Publication no. 92, p. 215233.

Guild, L.S., Cohen, W.B., and Kauffman, J.B., 2004, Detection of deforestation and land conversion in Rondônia, Brazil using change detection techniques : International Journal of Remote Sensing, v. 25, no. 4, p. 731-750.

Gupta, R.P., 2003, Remote Sensing Geology ( $2^{\text {nd }}$ ed.) : Springer-Verlag, New York, NY, $655 \mathrm{p}$.

Hancock, P.L., 1985, Brittle microtectonics - principles and practice : Journal of Structural Geology, v. 7, no. 3-4, p. 437-457. 
Harris, A.G., Tuttle, E., and Tuttle, S.D., 2004, Geology of National Parks (6 $6^{\text {th }}$ ed.) : Kendall/Hunt Publishing Company, Dubuque, IA, 882 p.

Harvey, K.R., and Hill, G.J.E., 2001, Vegetation mapping of a tropical freshwater swamp in the Northern Territory, Australia - a comparison of aerial photography, Landsat TM and SPOT satellite imagery : International Journal of Remote Sensing, v. 22, no. 15, p. 2911-2925.

Hintze, L.F., 1988, Geologic History of Utah - A Field Guide to Utah's Rocks in Kowallis, B.J. (ed.) : Brigham Young University Geology Studies, Special Publication no. 7, Provo, UT, 202 p.

Hintze, L.F., 1997, Geologic Highway Map of Utah : Map reference, Brigham Young University Geology Studies, Special Publication no. 3, Provo, UT.

Hodgson, R.A., 1961, Regional study of jointing in Comb Ridge - Navajo Mountain area, Arizona and Utah : American Association of Petroleum Geologists Bulletin, v. 45 , no. 1, p. $1-38$.

Huang, K., 2002, A synergistic automatic clustering technique for multispectral image analysis : Photogrammetric Engineering and Remote Sensing, v. 68, no. 1, p. 3340.

Huang, Q., and Angelier, J., 1989, Fracture spacing and its relation to bed thickness : Geological Magazine, v. 126, is. 4, p. 355-362.

Jensen, J.R., 2000, Remote Sensing of the Environment - An Earth Resource Perspective : Prentice-Hall, Inc., Upper Saddle River, NJ, 544 p.

Jensen, J.R., 2005, Introductory Digital Image Processing - A Remote sensing Perspective ( $3^{\text {rd }}$ ed.) : Pearson Education, Inc., Upper Saddle River, NJ, 526 p.

Karathanassi, V., Andronis, V., and Rokos, D., 2003, The radiative impact of aerosols emanating from biomass burning, through the Minnaert constant : International Journal of Remote Sensing, v. 24, no. 24, p. 5135-5145.

Kattenhorn, S.A., Aydin, A., and Pollard, D.D., 2000, Joints at high angles to normal fault strike - an explanation using 3-D numerical models of fault-perturbed stress fields : Journal of Structural Geology, v. 22, is. 1, p. 1-23.

Kearey, P., and Vine, F.J., 1996, Global Tectonics (2 ${ }^{\text {nd }}$ ed.) : Blackwell Science Ltd., Malden, MA, $333 \mathrm{p}$.

Kennedy, H. (ed.), 2001, The ESRI Press Dictionary of GIS Terminology : ESRI Press, Redlands, CA, $116 \mathrm{p}$. 
La Pointe, P.R., 2002, Derivation of parent fracture population statistics from trace length measurements of fractal fracture populations : International Journal of rock Mechanics and Mining Sciences, v. 39, is. 3, p. 381-388.

La Pointe, P.R., and Hudson, J.A., 1985, Characterization and Interpretation of Rock Mass Joint Patterns - Special Paper no. 199 : The Geological Society of America, Inc., Boulder, $\mathrm{CO}, 37 \mathrm{p}$.

Lillesand, T.M., Kiefer, R.W., and Chipman, J.W., 2004, Remote Sensing and Image Interpretation ( $5^{\text {th }}$ ed.) : John Wiley and Sons, Inc., New York, NY, 763 p.

Lo, C.P., and Yeung, A.K.W., 2002, Concepts and Techniques of Geographic Information Systems : Prentice-Hall, Inc., Upper saddle River, NJ, 492 p.

Longley, P.A., Goodchild, M.F., Maguire, D.J., and Rhind, D.W., 2001, Geographic Information Systems and Science : John Wiley and Sons, Ltd., New York, NY, $454 \mathrm{p}$.

Lorenz, J.C., and Cooper, S.P., 2001, Interpreting fracture patterns in sandstones interbedded with ductile strata at the Salt Valley Anticline, Arches National Park, Utah : Sandia Report no. SAND2001-3517, Sandia National Laboratories, Albuquerque, NM, Livermore, CA, $52 \mathrm{p}$.

Loveland, T.R., Zhiliang Z., Ohlen, D.O., Brown, J.F., Reed, B.C., and Yang, L., 1999, An analysis of the IGBP global landcover characterization process :

Photogrammetric Engineering and Remote Sensing, v. 65, no. 9, p. 1021-1032.

Marrett, R., and Allmendinger, R.W., 1991, Estimates of strain due to brittle faulting sampling of fault populations : Journal of Structural Geology, v. 13, no. 6, p. 735738.

Marrett, R., and Allmendinger, R.W., 1992, Amount of extension on "small" faults - An example from the Viking graben : Geology, v. 20, no. 1, p. 47-50.

Matthai, S.K., Aydin, A., Pollard, D.D., and Roberts, S.G., 1998, Numerical simulation of departures from radial drawdown in a faulted sandstone reservoir with joints and deformation bands in Jones, G., Fisher, Q.J., Knipe, R.J. (eds.) : Faulting, Fault Sealing and Fluid Flow in Hydrocarbon Reservoirs, The Geological Society of London, Special Publication no. 147, p. 157-191.

Mauldon, M., Dunne, W.M., and Rohrbaugh Jr., M.B., 2001, Circular scanlines and circular windows - new tools for characterizing the geometry of fracture traces : Journal of Structural Geology, v. 23, is. 2-3, p. 247-258. 
Maxwell, S.K., Hoffer, R.M., and Chapman, P.L., 2002, AVHRR composite period selection for land cover classification : International Journal of Remote Sensing, v. 23 , no. 23 , p. $5043-5059$.

Mitchell, A., 1999, The ESRI ${ }^{\circledR}$ Guide to GIS Analysis - v. 1, Geographic Patterns and Relationships : ESRI, Inc., Redlands, CA, 186 p.

Moores, E.M., and Twiss, R.J., 1995, Tectonics : W.H. Freeman and Company, New York, NY, $415 \mathrm{p}$.

Nackaerts, K., Vaesen, K., Lizarraga, I., Muys, B., and Coppin, P., 2004, Use of metatruth image concept to assess forest change detection accuracy at pixel level : International Journal of Remote Sensing, v. 25, no. 14, p. 2713-2723.

Narr, W., and Suppe, J., 1991, Joint spacing in sedimentary rocks : Journal of Structural Geology, v. 13, no. 9, p. 1037-1048.

Nelson, R.A., 1985, Geologic Analysis of Naturally Fractured Reservoirs : Gulf Publishing Company, Houston, TX, 320 p.

Odling, N.E., 1992, Network properties of a two-dimensional natural fracture pattern : Pure and Applied Geophysics, v. 138, no.1, p. 95-114.

Odling, N.E., 1997, Scaling and connectivity of joint systems in sandstones from western Norway: Journal of Structural Geology, v. 19, no. 10, p. 1257-1271.

Odling, N.E., Gillespie, P., Bourgine, B., Castaing, C., Chilès, J.-P., Christensen, N.P., Fillion, E., Genter, A., Olsen, C., Thrane, L., Trice, R., Aarseth, E., Walsh, J.J., and Watterson, J., 1999, Variations in fracture system geometry and their implications for fluid flow in fractured hydrocarbon reservoirs : Petroleum Geoscience, v. 5, is. 4, p. 373-384.

Olthof, I., Butson, C., and Fraser, R., 2005, Signature extension through space for northern landcover classification - A comparison of radiometric correction methods : Remote Sensing of Environment, v. 95, is. 3, p. 290-302.

Özkan, C., and Sunar Erbek, F., 2005, Comparing feature extraction techniques for urban land-use classification : International Journal of Remote Sensing, v. 26, no. 4, p. 747-757.

Paine, D.P., and Kiser, J.D., 2003, Aerial Photography and Image Interpretation (2 $2^{\text {nd }}$ ed.) : John Wiley and Sons, Inc., Hoboken, NJ, 632 p. 
Peacock, D.C.P., Harris, S.D., and Mauldon, M., 2003, Use of curved scanlines and boreholes to predict fracture frequencies : Journal of Structural Geology, v. 25, is. 1, p. 109-119.

Peddle, D.R., Johnson, R. L., Cihlar, J., and Latifovic, R., 2004, Large area forest classification and biophysical parameter estimation using the 5-Scale canopy reflectance model in Multiple-Forward-Mode : Remote Sensing of Environment, v. 89 , is. 2 , p. $252-263$.

Pollard, D.D., and Aydin, A., 1988, Progress in understanding jointing over the past century : Geological Society of America Bulletin, v. 100, is. 8, p. 1181-1204.

Post, R.M., Kemeny, J.M., and Murphy, R., 2001, Image processing for automatic extraction of rock joint orientation data from digital images in Elsworth, D., Tinucci, J.P., and Heasley, K.A. (eds.) : Rock Mechanics in the National Interest $\left(38^{\text {th }}\right.$ U.S. Rock Mechanics Symposium, Washington, D.C.), Lisse, The Netherlands, Swets and Zeitlinger, B.V., p. 877-884.

Priest, S.D., and Hudson, J.A., 1976, Discontinuity spacings in rock : International Journal of Rock Mechanics and Mining Sciences and Geomechanics Abstracts, v. 13 , is. 5 , p. $135-148$.

Puissant, A., Hirsch, J., and Weber, C., 2005, The utility of texture analysis to improve per-pixel classification for high to very high spatial resolution imagery : International Journal of Remote Sensing, v. 26, no. 4, p. 733-745.

Raclot, D., Colin, F., and Puech, C., 2005, Updating land cover classification using a rule-based decision system : International Journal of Remote Sensing, v. 26, no. 7, p. 1309-1321.

Ramsay, J.G., and Huber, M.I., 1987, The Techniques of Modern Structural Geology - v. 2, Folds and Fractures : Academic Press, San Diego, CA, 700 p.

Reading, R.W., Godfrey, A.E., and Prevedel, D.A., 1998, Utah - A Geologic History, From Paleozoic to Present : Poster reference, Public Information Series no. 54, Utah Geological Survey, Salt Lake City, UT, USDA Forest Service Intermountain Region, GIS Center of Excellence, Ogden, UT.

Rees, W.G., Williams, M., and Vitebsky, P., 2003, Mapping landcover change in a reindeer herding area of the Russian Arctic using Landsat TM and ETM+ imagery and indigenous knowledge : Remote Sensing of Environment, v. 85, p. 441-452.

Renshaw, C.E., 1997, Mechanical controls on the spatial density of opening-mode fracture networks: Geology, v. 25, no. 10, p. 923-926. 
Rives, T., Razack, M., Petit, J.-P., and Rawnsley, K.D., 1992, Joint spacing - analogue and numerical simulations : Journal of Structural Geology, v. 14, no. 8-9, p. 925937.

Rohrbaugh Jr., M.B., Dunne, W.M., and Mauldon, M., 2002, Estimating fracture trace intensity, density, and mean length using circular scan lines and windows : American Association of Petroleum Geologists Bulletin, v. 86, no. 12, p. 20892104.

Rosenfield, G.H., and Fitzpatrick-Lins, K., 1986, A coefficient of agreement as a measure of thematic classification accuracy : Photogrammetric Engineering and Remote Sensing, v. 52, no. 2, p. 223-227.

Ruf, J.C., Rust, K.A., and Engelder, T., 1998, Investigating the effect of mechanical discontinuities on joint spacing: Tectonophysics, v. 295 , is. 1-2, p. 245-257.

Sabins, F.F., 1997, Remote Sensing - Principles and Interpretation ( $3^{\text {rd }}$ ed.) : W.H. Freeman and Company, New York, NY, 494 p.

Salem, F., Kafatos, M., El-Ghazawi, T., Gomez, R., and Yang, R., 2005, Hyperspectral image assessment of oil-contaminated wetland : International Journal of Remote Sensing, v. 26, no. 4, p. 811-821.

Schiewe, J., and Ehlers, M., 2005, A novel method for generating 3D city models from high resolution and multi-sensor remote sensing data : International Journal of Remote Sensing, v. 26, no. 4, p. 683-698.

Schlische, R.W., Young, S.S., Ackermann, R.V., and Gupta, A., 1996, Geometry and scaling relations of a population of very small rift-related normal faults : Geology, v. 24 , no. 8 , p. $683-686$.

Scholz, C.H., and Cowie, P.A., 1990, Determination of total strain from faulting using slip measurements : Nature, v. 346, no. 6287, p. 837-839.

Schowengerdt, R.A., 1997, Remote Sensing - Models and Methods for Image Processing $\left(2^{\text {nd }}\right.$ ed.) : Academic Press, San Diego, CA, 522 p.

Singhal, B.B.S., and Gupta, R.P., 1999, Applied Hydrogeology of Fractured Rocks : Kluwer Academic Publishers, Norwell, MA, 400 p.

Sprinkel, D.A., Chidsey, T.C., and Anderson, P.B. (eds.), 2003, Geology of Utah's Parks and Monuments ( $2^{\text {nd }}$ ed.) : Utah Geological Association, Publication no. 28, Salt Lake City, UT, Bryce Canyon Natural history Association, Bryce Canyon, UT, $562 \mathrm{p}$. 
Star, J., and Estes, J.; 1990; Geographic Information Systems - An Introduction;

Prentice-Hall, Inc., Englewood Cliffs, NJ, 303 p.

Stokes, W.L., 1986, Geology of Utah : Utah Museum of Natural History, Occassional

Paper no. 6, University of Utah, Salt Lake City, UT, Utah Geological and Mineral Survey, Salt Lake City, UT, 280 p.

Stow, D., Coulter, L., Kaiser, J., Hope, A., Service, D., Schutte, K., and Walters, A., 2003, Irrigated vegetation assessments for urban environments : Photogrammetric Engineering and Remote Sensing, v. 69, no. 4, p. 381-390.

Swain, P.H., and Davis, S.M. (eds.), 1978, Remote Sensing - The Quantitative Approach : McGraw-Hill, New York, NY, 396 p.

Taylor, J.C., Brewer, T.R., and Bird, A.C., 2000, Monitoring landscape change in the National Parks of England and Wales using aerial photo interpretation and GIS : International Journal of Remote Sensing, v. 21, nos. 13 \& 14, p. 2737-2752.

Tou, J.T., and Gonzalez, R.C., 1974, Pattern Recognition Principles : Addison-Wesley, Reading, MA, $377 \mathrm{p}$.

Twiss, R.J., and Moores, E.M., 1992, Structural Geology : W.H. Freeman and Company, New York, NY, 532 p.

USDA, 2002, APFO Imagery Products and Services - History on Film : Leaflet reference, Leaflet no. 571, U.S. Department of Agriculture, Farm Service Agency, Aerial Photography Field Office, Salt Lake City, UT.

USGS, 2000, Digital Orthophoto Quadrangles : Fact Sheet no. 039-00, U.S. Geological Survey.

Utah Geological Survey, 2001, Utah ! 100Years of Exploration ... and still the place to find oil and gas : Brochure reference, Public Information Series no. 71, Utah Geological Survey, Salt lake City, UT.

Utah Geological Survey, Geologic Map of the Arches National Park Area - Grand County, Utah : Postcard reference, Salt Lake City, UT.

The map is also available at http://geology.utah.gov/utahgeo/geomap/ pdf/archesnp.pdf (as of $28^{\text {th }}$ of July, 2005).

Van Coillie, F.M.B., Verbeke, L.P.C., and De Wulf, R.R., 2004, Previously trained neural networks as ensemble members - knowledge extraction and transfer : International Journal of Remote Sensing, v. 25, no. 21, p. 4843-4850. 
Walsh, J., Watterson, J., and Yielding, G., 1991, The importance of small-scale faulting in regional extension: Nature, v. 351, no. 6325, p. 391-393.

Walsh, J.J., and Watterson, J., 1992, Populations of faults and fault displacements and their effects on estimates of fault-related regional extension : Journal of Structural Geology, v. 14, no. 6, p. 701-712.

Wang, L., Sousa, W.P., and Gong, P., 2004, Integration of object-based and pixel-based classification for mapping mangroves with IKONOS imagery : International Journal of Remote Sensing, v. 25, no. 24, p. 5655-5668.

Wilkerson, C., 1993, Utah's Geologic History : Booklet reference, Public Information Series no. 19, Utah Geological Survey, Salt Lake City, UT.

Wu, H., and Pollard, D.D., 1995, An experimental study of the relationship between joint spacing and layer thickness : Journal of Structural Geology, v. 17, no. 6, p. 887905.

Zeiler, M., 1999, Modeling Our World - The ESRI ${ }^{\circledR}$ Guide to Geodatabase Design : ESRI, Inc., Redlands, CA, 199 p.

Zhang, Y., 2001, Detection of urban housing development by fusing multisensor satellite data and performing spatial feature post-classification : International Journal of Remote Sensing, v. 22, no. 17, p. 3339-3355.

Zhao, G., and Johnson, A.M., 1991, Sequential and incremental formation of conjugate set of faults : Journal of Structural Geology, v. 13, no. 8, p. 887-895.

Zhao, G., and Johnson, A.M., 1992, Sequence of deformations recorded in joints and faults, Arches National Park, Utah : Journal of Structural Geology, v. 14, no. 2, p. 225-236.

Zhou, Q., and Robson, M., 2001, Automated rangeland vegetation cover and density estimation using ground digital images and a spectral-contextual classifier : International Journal of Remote Sensing, v. 22, no. 17, p. 3457-3470. 